\title{
Strafbaarstelling van nieuwe vormen van ongewenste seksuele gedragingen in Nederlandse zedenwetgeving
}

Jeroen ten Voorde

\section{Inleiding en onderzoeksvragen}

\section{I.I De seksuele delicten}

Op twee plaatsen in het Wetboek van Strafrecht (Sr) vinden we strafbare feiten inzake de zeden, namelijk Titel XIV van het Tweede Boek (Misdrijven tegen de zeden) en Titel VI van het Derde Boek (Overtredingen tegen de zeden). Welke gedragingen vallen in het Nederlandse strafrecht onder de zedendelicten? Dat zijn allereerst bepaalde gedragingen die verband houden met seksualiteit. De wetgever sprak ten aanzien hiervan over gedragingen tegen de goede zeden of eerbaarheid. ${ }^{\mathrm{I}} \mathrm{Dit}$ zijn in het huidige strafrecht onrechtmatige menselijke gedragingen die, al dan niet direct, zijn gericht op een andere menselijke persoon of dier en die gepaard (kunnen) gaan met lust en opwinding en voortkomen uit of verband houden met geslachtsdrift. Het gaat om de strafbare feiten die in de art. 239-25I Sr zijn neergelegd en, voor zover het zedendelicten tegen dieren betreft, in art. 254 en 254a Sr. Tot de zedendelicten behoren ook gedragingen die verband houden met het gebruik van alcoholhoudende drank (art. 252 en art. $453 \mathrm{Sr}$ ) en het laten verrichten van gevaarlijke arbeid door minderjarigen (art. $253 \mathrm{Sr}$ ). Deze strafbepalingen noemde de wetgever delicten tegen de zedelijkheid. Zij houden geen verband met seksualiteit. ${ }^{2}$ In dit preadvies wordt slechts ingegaan op de delicten tegen de goede zeden die tegen mensen zijn gericht. ${ }^{3}$ Deze delicten worden in het vervolg seksuele delicten genoemd.

* $\quad$ Prof. mr. J.M. ten Voorde is universitair hoofddocent straf- en strafprocesrecht aan de Universiteit Leiden en als bijzonder hoogleraar strafrechtsfilosofie (leerstoel Leo Polak) verbonden aan de Rijksuniversiteit Groningen.

I H.J. Smidt, Geschiedenis van het Wetboek van Strafrecht. Volledige verzameling van regeeringsontwerpen, gewisselde stukken, gevoerde beraadslagingen enz. (bewerkt door J.W. Smidt), Tweede Deel, Haarlem: H.D. Tjeenk Willink I89I, p. 278-279 (hierna: Smidt II I89I).

2 Onder de tweede categorie vielen oorspronkelijk meer strafbaarstellingen. Bijv. art. 254bis (oud) en 457 (oud) Sr (strafbaarstellingen in verband met kansspelen) en art. 45Iter (oud) en 45Iquater (oud) Sr (strafbaarstellingen in verband met openlijk tentoonstellen van middelen ter voorkoming of verstoring van zwangerschap).

3 Zie over de strafbaarstellingen ontucht met dieren en dierenpornografie R. Kool, "Eer is teer". Een beschouwing over de grondslag van de strafbaarstelling van seks met dieren en dierenpornografie', in: J.P. van der Leun e.a. (red.), De vogel vrij (Moerings-bundel), Den Haag: Boom Lemma uitgevers 20II, p. 353-366. 


\section{I.2 Beknopte geschiedenis van de door de seksuele delicten beschermde rechtsbelangen}

De geschiedenis van de seksuele delicten wijst uit dat zij een allesbehalve rustig bezit zijn. Dat blijkt niet alleen uit het aantal wetswijzigingen sinds de invoering van Titel XIV en Titel VI met de inwerkingtreding van het Wetboek van Strafrecht in I886.4 Op het niveau van de door die strafbaarstellingen te beschermen rechtsgoederen of -belangen valt eveneens een ontwikkeling waar te nemen. Over deze ontwikkeling kan het volgende, bij wijze van samenvatting, worden opgemerkt.

Aan de seksuele delicten lag bij de totstandkoming van het Wetboek van Strafrecht de opvatting ten grondslag dat slechts die handelingen strafbaar mogen worden gesteld die de 'uitwendige orde der maatschappij' verstoren. ${ }^{5}$ De wetgever maakte een strikt onderscheid tussen recht en ethiek. Hij mocht geen zedenmeester of 'photograaf van de volksovertuiging' zijn. ${ }^{6}$ Hieruit volgde dat slechts dat handelen (openbare schennis van de eerbaarheid en handelingen verband houdende met pornografie daaronder begrepen) strafbaar mocht worden gesteld dat de wilsvrijheid van het slachtoffer ontkende, of dat was gericht tegen een persoon die zijn wil niet vrijelijk kon bepalen (art. 239-25I Sr).7 De wetgever heeft zich bij het bepalen welk handelen wel en niet strafbaar werd gesteld en het formuleren van de strafbaarstellingen daar destijds telkens goeddeels aan gehouden. ${ }^{8}$

$\mathrm{Na}$ de inwerkingtreding van het Wetboek van Strafrecht in 1886 veranderden de opvattingen over de taak van het strafrecht met betrekking tot seksualiteit. ${ }^{9}$ Tijdens de parlementaire behandeling van de in I9II in werking getreden Wet bestrijding van zedeloosheid verzekerde de minister van Justitie dat de staat geen zedenmeester is ${ }^{\mathrm{IO}}$ en dat de rechter zich moest onthouden van 'overdreven preutschheid'. ${ }^{\text {II }}$ De wetswijzigingen gaven echter blijk van een andere benadering van de zedendelicten dan ten tijde van de totstandkoming van het Wetboek van Strafrecht. In de Wet van I9II stond niet alleen de wilsvrijheid van het slachtoffer centraal, ${ }^{12}$ maar ook de (op christelijke ethiek gestoelde) openbare zedeloosheid. ${ }^{13}$ Met behulp van de strafwet moest het 'openbaar leven rein' worden gehouden. ${ }^{14}$ Met de invoering van de Wet ter bestrijding van zedeloosheid werd de strafbaar-

4 Titel XIV is sinds I886 42 keer gewijzigd, Titel VI I5 keer (stand op I juni 2or6).

5 Vgl. H.J. Smidt, Geschiedenis van het Wetboek van Strafrecht. Volledige verzameling van regeeringsontwerpen, gewisselde stukken, gevoerde beraadslagingen enz. (bewerkt door J.W. Smidt), Eerste Deel, Haarlem: H.D. Tjeenk Willink I89I, p. 17, 27; Smidt II I89I, p. 65.

6 Smidt II I89I, p. 289. Vgl. A.J.A. van Dorst e.a., Staatscommissie voor de zamenstelling van een Wetboek van Strafregt, Notulen Deel I, Tilburg: Katholieke Universiteit Tilburg I976, p. 288.

$7 \quad$ J.M. van Bemmelen, 'De zedendelicten', Tijdschrift voor Strafrecht I96I, p. 239.

8 Zie over de totstandkoming van Titel XIV van het Tweede Boek van het Wetboek van Strafrecht R.S.B. Kool, De strafwaardigheid van seksueel misbruik (diss. Rotterdam), Deventer: Gouda Quint I999, p. 40-55.

$9 \quad$ Kool ig99, p. 56-77.

Io Kamerstukken I I9Io/II, 28, nr. 28, p. 49I; Handelingen II 2I februari I9II, p. I454.

II Kamerstukken II I908/o9, 293, nr. 3, p. 4 .

I2 Kamerstukken II I9Io/II, 56, nr. 3, p. I6.

I3 Kamerstukken II I9Io/II, 56, nr. 2, p. I6; Kamerstukken II I9Io/II, 28, nr. 28, p. 508-509; Handelingen II I9Io/II, 2I februari IgII, p. I453.

I4 Kamerstukken II I9o8/o9, 293, nr. 3, p. 4, 5; Kamerstukken I I9Io/II, 28, nr. 28, p. 508. Vgl. Kamerstukken II I9Io/II, 56, nr. 2, p. I5, 2I; Handelingen II 2I februari I9II, p. I454. 
stelling van pornografie uitgebreid (art. 240 en 240 obis (oud) $\mathrm{Sr}$ ), ${ }^{15}$ homoseksuele ontucht en het verleiden van een minderjarige tot het plegen van ontucht strafbaar gesteld (art. 248bis (oud) en art. 248ter (oud) Sr), het bordeelverbod ingevoerd (art. 25obis (oud) Sr), vrouwenhandel strafbaar gesteld (art. 250ter (oud) Sr) en hij die voordeel trekt uit de ontucht van een vrouw (de souteneur) strafbaar (art. 432, $3^{\circ}$ (oud) $\mathrm{Sr}$. $^{16}$

Vanaf de jaren zestig van de vorige eeuw ontstond opnieuw discussie over de zedenwetgeving. ${ }^{17}$ Een adviescommissie formuleerde nieuwe uitgangspunten voor de zedenwetgeving. Zij constateerde dat ten aanzien van seksualiteit de maatschappelijke opvattingen sterk waren gewijzigd in de richting van een zekere 'vrijmoedigheid', die kan worden beschouwd 'als de positieve kant van een proces van bewustwording, ontplooiing of emancipatie van individuen, wier individuele vrijheid om aan hun geestelijke en psychische onafhankelijkheid ook uitdrukking te kunnen geven onder meer wordt bevestigd door de artt. 8, 9 en Io' van het EVRM. Die rechten beschermen niet alleen de vrijheid van het individu, zij stellen aan die vrijheden ook grenzen (in het tweede lid van de genoemde bepalingen) zonder 'essentialistische uitspraken (...) over de verderfelijkheid van personen of handelingen'. De wetgever had volgens de commissie een 'beperkte taak (...) om door de inschakeling van het strafrecht individuen in de openbaarheid te beschermen tegen aanstoot of kwetsing als gevolg van de verregaande sexuele vrijmoedigheid van anderen. Zonder als censor morum op te treden zal de wetgever enkele grenzen moeten trekken voor het openbare leven, waarbij de vrijheden van de burgers ten opzichte van elkaar redelijk worden gewaarborgd. ${ }^{18}$ De commissie stelde voorop dat het strafrecht ultimum remedium is; het mocht pas in beeld komen als andere (bestuurlijke) middelen tekortschoten. ${ }^{19}$ Een en ander leidde tot voorstellen om de strafbaarstelling van pornografie in te perken en onderscheid te maken tussen vrijwillige en onvrijwillige prostitutie. Handelingen die onvrijwillige prostitutie bevorderen, teweegbrengen en in stand houden moesten strafbaar blijven.

In eerste instantie gebruikte de formele wetgever deze opvattingen als vertrekpunt voor herziening van de strafrechtelijke zedenwetgeving. Dat uitgangspunt, 'de bescherming van de wilsvrijheid van de burger in de inrichting van haar of zijn seksuele leven', ${ }^{20}$ werd nadien onder meer uitgelegd als 'het seksuele zelfbeschikkingsrecht, de integriteit van het menselijk lichaam en de bescherming tegen

I5 Zie daarover T.M. Schalken, Pornografie en strafrecht. Beschouwingen over het pornografiebegrip en zijn juridische hanteerbaarheid (diss. Amsterdam VU), Arnhem: Gouda Quint/Brouwer en Zn. I972, p. 29-45.

I6 Zie over de lotgevallen van de laatste drie strafbaarstellingen C.P.M. Cleiren en J.M. ten Voorde, 'Prostitutie en souteneurschap in het strafrecht: rechtsbelangen in beweging', Ars Aequi 20r6, p. 398-405.

I7 De strafbaarstellingen van overspel (art. 24I Sr) en homoseksuele ontucht (art. 248bis Sr) werden begin jaren zeventig ingetrokken. Zie resp. Wet van 6 mei I97I, Stb. 29I en Wet van 8 april I97I, Stb. 2I2.

I8 Adviescommissie zedelijkheidswetgeving, Tweede interimrapport van de adviescommissie zedelijkheidswetgeving, 's-Gravenhage: Staatsuitgeverij I973, p. II; Adviescommissie zedelijkheidswetgeving, Eindrapport van de adviescommissie zedelijkheidswetgeving, 's-Gravenhage: Staatsuitgeverij I980, p. I3.

I9 Adviescommissie zedelijkheidswetgeving, Derde interimrapport van de adviescommissie zedelijkheidswetgeving, 's-Gravenhage: Staatsuitgeverij I977, p. I2.

20 Kamerstukken II I988/89, 20 930, nr. 3, p. 4. Zie ook Kamerstukken II I979/8o, I5 836, nr. 3, p. I, 2; Kamerstukken II I983/84, I8 202, nrs. I-3, p. II; Kamerstukken II 2001/02, 27 745, nr. 6, p. 5 . 
inbreuken daarop'. ${ }^{21}$ Deze door de wetgever genoemde 'beginselen' dienden echter, anders dan de adviescommissie voorstond, bij strafbaarstelling 'mede een rol' te spelen. In de afweging om al dan niet tot strafbaarstelling over te gaan werd na verloop van tijd 'de bescherming van kwetsbare personen toch een van de belangrijkste doeleinden van de zedelijkheidswetgeving'. ${ }^{22}$ De nadruk op bescherming (van de lichamelijke en geestelijke gezondheid van (minderjarige) slachtoffers) heeft - zo lijkt het - de seksuele vrijheid daaraan steeds meer ondergeschikt gemaakt. ${ }^{23}$ Dat laat zich verklaren door de over seksualiteit en seksueel geweld veranderende opvattingen in Nederland (in het bijzonder leidde de bewustwording van de aard en omvang van seksueel geweld tegen vrouwen en kinderen tot prioritering van de bescherming van slachtoffers van seksuele delicten) en de verschillende in het leven geroepen internationale instrumenten (van de Verenigde Naties, de Raad van Europa en de Europese Unie) die de bescherming van slachtoffers van seksuele delicten op de voorgrond stellen, in het bijzonder van minderjarigen. Door middel van door het Europees Hof voor de Rechten van de Mens ontwikkelde positieve verplichtingen wordt ook Nederland gewezen op de plicht tot strafbaarstelling van bepaalde seksuele handelingen. ${ }^{24}$

Schade heeft als criterium voor strafbaarstelling in verschillende (nieuwe) strafbepalingen aan belang gewonnen. ${ }^{25} \mathrm{Bij}$ schade gaat het om daadwerkelijk aan één of meer personen toegebrachte schade (waaronder ook psychische schade wordt verstaan) en om schade die door bepaald gedrag in het leven kan worden geroepen en vanwege de ernst van die mogelijke schade moet worden voorkomen. Het gevaar voor schade heeft als criterium voor strafbaarstelling bij verschillende seksuele delicten een steeds prominentere plaats gekregen. ${ }^{26}$ Geconstateerd kan worden dat het voorkomen van schade (door het vertonen van pornografisch materiaal aan minderjarigen, het bezit of verspreiden van kinderpornografie en het via internet doen van een voorstel tot een ontmoeting met het oogmerk om bijvoorbeeld ontuchtige handelingen met een minderjarige te plegen) in verband met de bescherming van minderjarigen wordt bezien. Daarmee lijkt gevaar voor schade geen afzonderlijk criterium. Eerder lijkt het een met de beschermingsgedachte verband houdend extra argument voor strafbaarstelling. Het benadrukken van bescherming lijkt het eveneens mogelijk te hebben gemaakt dat strafbaarstellingen tegenwoordig ook worden gerechtvaardigd ter bestrijding van een bepaalde

2I Wilsvrijheid werd - anders dan de adviescommissie leek voor te staan - ruim uitgelegd. Ook seksuele handelingen met iemand met verminderd bewustzijn (of: verminderde wilsvrijheid) werden strafbaar gesteld (art. 243 Sr). Zie Kamerstukken II 2000/oI, 27 745, nr. 3, p. 9; Kamerstukken II 2001/02, 27 745, nr. 6, p. 22.

22 Kamerstukken II I989/90, 20 930, nr. 8, p. 5-6.

23 Kamerstukken II I993/94, 23 682, nr. 3, p. I, 3; Kamerstukken II 200o/oI, 27 745, nr. 3, p. 4. Zie ook Kamerstukken II 20I2/I3, 33 580, nr. 3, p. 2, I6 (over art. 248f Sr).

24 Kamerstukken II 200I/02, 27 745, nr. 6, p. 5-6; Kamerstukken II 20I2/I3, 33 580, nr. 3, p. 2. Zie hierover in het bijzonder K. Lindenberg, 'Zedendelicten en positieve verplichtingen', in: J.H. Gerards en C. Sieburgh (red.), De invloed van fundamentele rechten op het materiële recht, Deventer: Kluwer 20I3, p. 50I-529.

25 Kamerstukken II I980/8I, I5 836, nr. 6, p. 6 (art. 240a Sr); Kamerstukken II 200o/or, 27 745, nr. 3, p. 4, 7 (art. 240b en 248c Sr); Kamerstukken II 200I/02, 27 745, nr. 6, p. 8-I0; Kamerstukken II 2008/og, 3I 8Io, nr. 3, p. 5, 6; Kamerstukken II 2008/o9, 3i 8Io, nr. 7, p. 7 (art. 248d en 248e Sr).

26 Zie R.S.B. Kool, 'Better safe than sorry? Over de legitimiteit van strafbaarstelling van seksueel corrumperen van minderjarigen en grooming', DD 2010/80; C. Kelk, 'Uitdijende strafbaarheid van onzedelijk handelen', Ars Aequi 2015, p. 522; M. Moerings, 'Onder het mom van de bescherming van het kind. De aanscherping van de zedenwet', Proces 2004, p. I02-Io6. 
door de meerderheid van de bevolking niet geaccepteerde (pedoseksuele) subcultuur. ${ }^{27}$ Zo krijgen seksuele delicten (opnieuw) een meer ethische lading, hetgeen er volgens sommigen toe leidt dat de overheid zich te veel op het privéterrein van (minderjarige) burgers begeeft. Daardoor zou de seksuele vrijheid, die volgens hen nog steeds het uitgangspunt voor de zedenwetgeving zou moeten vormen, onder druk zijn komen te staan. ${ }^{28}$

Wat leert het voorgaande ons? De seksuele delicten in het Wetboek van Strafrecht lijken niet zonder meer te zijn gebaseerd op voor alle seksuele delicten geldende, identiek uitgelegde, rechtsbelangen. Seksuele vrijheid draagt er nog steeds aan bij dat de wetgever zich ten aanzien van seks en seksualiteit terughoudend moet opstellen. Tegelijkertijd vormt het strafrecht een van de belangrijke onderdelen van overheidsbeleid om bepaalde seksuele handelingen krachtig te bestrijden, daartoe deels mede verplicht door de figuur van de positieve verplichtingen. Een complicerende factor in de discussie over de inhoud van seksuele delicten is dat de positie van minderjarigen niet geheel duidelijk is. Enerzijds vormt het beschermen van minderjarigen een belangrijke basis voor het strafbaar stellen van ongewenst seksueel handelen en vormt het een aanjager voor het aanscherpen van de zedenwetgeving (ook wanneer die op meerderjarigen betrekking heeft), anderzijds roept deze beschermingsgedachte vragen op van afbakening met de door de overheid te garanderen seksuele vrijheid die tot op zekere hoogte ook aan adolescente minderjarigen zou moeten worden geboden. Voor de rechtspraktijk lijkt het daarom niet eenvoudig om bij de uitleg van delictsbestanddelen (en meer in het algemeen bij het bepalen van de uiterste grenzen van een strafbaarstelling) houvast te vinden in de aan seksuele delicten ten grondslag liggende rechtsbelangen.

\section{I.3 Dit preadvies: seksuele delicten en internet}

De complexiteit van de seksuele delicten blijkt niet alleen uit telkens gewijzigde ethische opvattingen over seksualiteit en de daarmee samenhangende vraag welke rol voor de wetgever en rechter met betrekking tot gedragingen die met seksualiteit verband houden is weggelegd. Technologische ontwikkelingen brengen nieuwe seksuele handelingen met zich mee waarbij de vraag is of zij telkens dermate problematisch zijn, dat zij onder het bereik van de strafwet moeten worden gebracht. Dat dergelijke ontwikkelingen invloed uitoefenen op de zedenwetgeving is niet nieuw. In IgII werd art. $240 \mathrm{Sr}$ (waarin onder andere strafbaar is gesteld het verspreiden van pornografisch materiaal) mede gewijzigd omdat het procedé van het vervaardigen van foto's sinds I 886 sterk was vereenvoudigd. ${ }^{29}$

Tegenwoordig zijn de opkomst en groei van sociale media ook voor de seksuele delicten van belang..$^{30}$ Onder sociale media worden verstaan applicaties op het internet die het vervaardigen en uitwisselen van zogeheten 'user generated

27 Kamerstukken II 200I/02, 27 745, nr. 6, p. 9; Kamerstukken I 2001/02, 27 745, nr. 299b, p. 2; Kamerstukken I 2009/IO, 3I 808 (RI872), nr. C, p. 8; Kamerstukken II 2015/I6, 34 372, nr. 3, p. 7I.

28 J. Gooren, Een overheid op drift? De strafrechtelijke beheersing van seks en jongeren (diss. Leiden), Leiden: E.M. Meijers Instituut 2016.

29 Kamerstukken II I908/09, 293, nr. 3, p. 3.

30 E. Lievens, 'Bullying and Sexting in Social Networks: Protecting Minors from Criminal Acts or Empowering Minors to Cope with Risky Behaviour?', International Journal of Law, Crime and Justice 
content' mogelijk maken. 'User generated content' wordt omschreven als de som van alle manieren waarop mensen gebruikmaken van internet. ${ }^{3 \mathrm{I}}$ Sociale media zijn dus onlosmakelijk met internet verbonden. Internet heeft het maken, bewerken, verspreiden en bezitten van foto's, films, gespreksopnamen en dergelijke sterk vereenvoudigd en voor een steeds groter publiek toegankelijk gemaakt. ${ }^{32} \mathrm{Het}$ gebruik kunnen maken van draadloos internet op de inmiddels niet meer weg te denken mobiele telefoons (smartphones) en tablets, heeft het gebruik van internet, en daarmee sociale media, verder vereenvoudigd, vergroot en naar (bijna) alle denkbare plaatsen verspreid: in huis, op het werk, op straat, in winkels en winkelcentra, in de auto of het openbaar vervoer, in cafés en restaurants, op sportvelden, in zwembaden, kortom alle openbare en niet-openbare ruimten.

De betekenis van sociale media, draadloos internet en op internet aangesloten mobiele telefoons (met applicaties voor het maken van beeld en geluid), samengevat informatie- en communicatietechnologie, ${ }^{33}$ voor onze samenleving kan niet worden onderschat. Internet biedt mensen toegang tot de wereld. Van gebruikers van internet wordt aangenomen dat zij grote vrijheid genieten. Het behoeft weinig betoog dat zij proberen van die vrijheid maximaal gebruik te maken. Ongebreidelde internetvrijheid is voor overheden echter niet vanzelfsprekend. Zij zoeken, steeds vaker in internationaal verband, naar manieren om cyberspace te reguleren. ${ }^{34}$ Het reguleren daarvan houdt in niet onbelangrijke mate verband met het gebruik van internet om seksuele behoeften te bevredigen. Verschillende gedragingen op internet die met seks verband houden staan in de schijnwerpers. In dit preadvies worden er zes behandeld: kinderpornografie, wraakporno, seksuele afpersing, sexting, sexchatting en grooming. Deze volgorde is bepaald door de aard van de gedragingen. Waar kinderpornografie te maken heeft met afbeeldingen

20I4, p. 252. Uit oogpunt van eenduidigheid is gekozen voor de Nederlandse benaming in plaats van het Engelse social media.

3 I Vgl. A.M. Kaplan en M. Haenlein, 'Users of the World, Unite! The Challenges and Opportunities of Social Media', Business Horizons 2010, p. 59-68.

32 D. K. Citron en M.A. Franks, 'Criminalizing Revenge Porn', Wake Forest Law Review 20I4, p. 350.

33 De term informatie- en communicatietechnologie vinden we onder andere in het Verdrag van de Raad van Europa inzake de bescherming van kinderen tegen seksuele uitbuiting en seksueel misbruik (Verdrag van Lanzarote) van 25 oktober 2007, Trb. 2008, 58. In Nederlandse wetgeving worden de begrippen geautomatiseerd werk en communicatiedienst gebruikt. De wet verstaat onder geautomatiseerd werk 'een inrichting die bestemd is om langs elektronische weg gegevens op te slaan, te verwerken en over te dragen' (art. 8osexies Sr). In het wetsvoorstel Computercriminaliteit III wordt de definitie van geautomatiseerd werk gewijzigd in: 'een apparaat of groep van onderling verbonden of samenhangende apparaten, waarvan er één of meer op basis van een programma automatisch computergegevens verwerken' (Kamerstukken II 2015/16, 34 372, nr. 2). De term communicatiedienst ontbeert een wettelijke omschrijving. Een omschrijving wordt afgeleid uit art. I26la onder b Sv waarin een definitie is gegeven van de gebruiker van een communicatiedienst. Van een communicatiedienst wordt gesproken wanneer een dienst de mogelijkheid biedt dat communicatie met behulp van een geautomatiseerd werk plaatsvindt. Geautomatiseerd werk en communicatiedienst verwijzen kort gezegd naar 'technologieën waarmee verbinding kan worden gemaakt met het internet' (C.P.M. Cleiren, J.H. Crijns en M.J.M. Verpalen (red.), Tekst \& Commentaar Strafrecht, Deventer: Kluwer 20I4, aant. 7d bij art. 24ob (hierna: T\&C Sr)). Daaronder worden onder meer personal computers, smartphones en tablets verstaan. Over de reikwijdte van het begrip geautomatiseerd werk kan worden gediscussieerd. Zie B.J. Koops, C. Conings en F. Verbruggen, Zoeken in computers naar Nederlands en Belgisch recht. Welke plaats hebben 'digitale plaatsen' in de systematiek van opsporingsbevoegdheden?, Oisterwijk: Wolf Legal Publishers 20I6, p. I2-I4.

34 M.L. Mueller, Ruling the Root. Internet Governance and the Taming of Cyberspace, Cambridge, Massachusetts/Londen, England: The MIT Press 2009. 
van seksuele gedragingen, gaat grooming over het voeren van seksuele gesprekken met een minderjarige met als doel het realiseren van een ontmoeting alwaar die minderjarige seksueel wordt misbruikt. Wraakporno, seksuele afpersing, sexting en sexchatting liggen daar tussen in, al staat daarin zoals we zullen zien het voeren van gesprekken steeds meer centraal. Hoewel deze volgorde kan worden gerationaliseerd, heeft ze ook iets willekeurigs. Dat houdt verband met de complexiteit van de te bespreken fenomenen, die uiteenlopende gedragingen betreffen die gelet op de verschillende in het geding zijnde rechtsbelangen onder het bereik van nogal wat strafbaarstellingen, verspreid over het Wetboek van Strafrecht, blijken te kunnen vallen.

\section{Kinderpornografie}

Nationaal en internationaal bestaat grote bezorgdheid over het vervaardigen, verspreiden en bezit van kinderporno. ${ }^{35}$ De opkomst van internet heeft de aandacht voor kinderporno verder doen toenemen en heeft dan ook geleid tot meer wetgevende maatregelen. In de rechtspraktijk zijn met betrekking tot kinderporno drie vragen actueel. De eerste vraag is wat onder een afbeelding moet worden verstaan. Deze term wordt zowel in Nederlandse wetgeving (onder andere art. 240, $240 \mathrm{a}$ en $24 \mathrm{ob} \mathrm{Sr}$ ) als in internationale rechtsinstrumenten gebruikt. De vraag is vooral of beelden van seksuele gedragingen van minderjarigen die op een webcam live te zien zijn kunnen worden beschouwd als het in onder andere art. 24ob Sr opgenomen bestanddeel afbeelding. De tweede vraag is of consensuele gedragingen van minderjarigen, bijvoorbeeld tieners die vrijwillig aan elkaar naaktfoto's of filmpjes met seksuele gedragingen (van zichzelf) sturen, strafbare kinderpornografie opleveren..$^{6}$ De Hoge Raad heeft hierover begin 2016 een belangrijke uitspraak gedaan, die bespreking behoeft. De derde vraag betreft het in art. 24ob Sr opgenomen bestanddeel 'schijnbaar betrokken', waarmee virtuele kinderpornografie strafbaar is gesteld. Ook dit bestanddeel heeft tot rechtspraak van de Hoge Raad geleid, die toelichting vraagt. Het bestanddeel 'zich door middel van een geautomatiseerd werk of met gebruikmaking van een communicatiedienst de toegang daartoe verschaft' verdient eveneens nadere toelichting. Deze vragen en onderwerpen worden besproken in par. 2 van dit preadvies.

\section{Wraakporno}

De laatste jaren is veel te doen over wraakporno en seksuele afpersing of sextortion. Een definitie van wraakporno luidt: 'the intentional embarrassment of identifiable individuals through the posting of nude images online'. ${ }^{37} \mathrm{Bij}$ wraakporno

35 Zie bijv. passages in de preambules bij: Facultatief Protocol inzake de verkoop van kinderen, kinderprostitutie en kinderpornografie bij het Verdrag inzake de rechten van het kind van 25 mei 2000, Trb. 200I, 63; Verdrag van de Raad van Europa inzake de bescherming van kinderen tegen seksuele uitbuiting en seksueel misbruik van 25 oktober 2007, Trb. 2008, 58; Richtlijn 201r/93/ EU van het Europees Parlement en de Raad van 13 december 201 I ter bestrijding van seksueel misbruik en seksuele uitbuiting van kinderen en kinderpornografie, en ter vervanging van Kaderbesluit 2004/68/JBZ van de Raad, PbEU 20II, L 335/I.

36 Aanhangsel Handelingen II 2015/16, nr. 1678.

37 S.R. Stroud, 'The Dark Side of the Online Self: A Pragmatist Critique of the Growing Plague of Revenge Porn', Journal of Mass Media Ethics 2014, p. I68. Zie voor iets andere omschrijvingen 
gaat het veelal om afbeeldingen van een al dan niet geheel naakte persoon die vrijwillig aan een ander (vaak de partner) zijn gegeven (of door deze zijn gemaakt), die deze op een later moment zonder toestemming van de eerste persoon verspreidt of dreigt te verspreiden..$^{3}$ Met het verspreiden van deze afbeeldingen wordt wraak genomen, bijvoorbeeld in reactie op het verbreken van de relatie. ${ }^{39}$ Wraakporno wordt als tamelijk problematisch beschouwd (zie par. 4.I). De minister van Veiligheid en Justitie heeft in antwoord op vragen vanuit de Tweede Kamer gewezen op het bestaande strafrechtelijke instrumentarium dat ook tegen wraakporno kan worden ingezet. Hij wees er bijvoorbeeld op dat wraakporno strafrechtelijk kan worden aangepakt via de strafbaarstelling van kinderpornografie (art. 240b Sr) en soms overtreding van art. $240 \mathrm{Sr}$ (verspreiding van pornografische afbeeldingen) oplevert, alsmede belediging (art. $266 \mathrm{Sr}$ ). Wanneer de afbeeldingen niet vrijwillig zijn afgestaan, komen andere strafbaarstellingen in beeld, zoals dwang (art. 284 Sr). Recentelijk werd aangekondigd dat het kopiëren van vertrouwelijke gegevens van personen, zoals seksueel getinte afbeeldingen, strafbaar wordt gesteld. $4^{\circ}$ Inmiddels is art. $138 \mathrm{c}$ Sr voorgesteld dat beoogt de strafbaarheid van dit gedrag te realiseren. ${ }^{4 \mathrm{I}}$ Het is de vraag of dat in de aanpak van wraakporno voldoende is. Van der Hof stelt dat het met de huidige strafbaarstellingen 'behelpen' is. ${ }^{42}$ Snijdt deze stelling hout en is art. $138 \mathrm{c} \mathrm{Sr}$ een welkome aanvulling? Bij deze vragen wordt in de derde paragraaf van dit preadvies stilgestaan.

\section{Sextortion}

De minister van Veiligheid en Justitie heeft erop gewezen dat wraakporno met een ander doel dan wraak op het internet kan worden geplaatst, bijvoorbeeld om 'meer en verdergaand materiaal te leveren'. ${ }^{43}$ Dergelijk handelen wordt sextortion genoemd (een samenvoeging van 'sex' en 'extortion'). ${ }^{44}$ Sextortion (ook wel seksuele afpersing of seksafpersing genoemd) wordt omschreven als 'gedrag waarbij seksueel materiaal wordt vergaard waarmee de afgebeelde vervolgens wordt afgeperst (...). Het motief kan gelegen zijn in het verkrijgen van geld of goederen, meer seksueel materiaal, [of] het verkrijgen van seksuele gunsten.' ${ }^{45}$ Volgens de minister

A. Levendowski, 'Using Copyright to Combat Revenge Porn', NYU Journal of Intellectual Property \& Entertainment Law 20I4, p. 425. Zie ook Z. Franklin, 'Justice for Revenge Porn Victims: Legal Theories to Overcome Claims of Civil Immunity by Operators of Revenge Porn Websites', California Law Review 2014, p. I306; S.H. Scheller, 'A Picture Is Worth a Thousand Words: The Legal Implications of Revenge Porn', Carolina Law Review 20I5, p. $55^{8}$.

38 Citron en Franks 20I4, p. 346.

39 S. van der Hof, 'Wraakporno op internet. Een verkenning van de (on)mogelijkheden voor een strafrechtelijke aanpak', Ars Aequi 20I6, p. 54; Conclusie A-G Hofstee, ECLI:NL:PHR:2015:2649, punt 9; Franklin 20I4, p. I304; J.K. Stokes, 'The Indecent Internet: Resisting Unwarranted Internet Exceptionalisms in Combating Revenge Porn', Berkeley Technology Law Journal 20I4, p. 930.

Aanhangsel Handelingen II 20I4/I5, nr. 933; Kamerstukken II 20I4/I5, 28 684, nr. 443; Aanhangsel Handelingen II 20I4/I5, nr. 2837; Kamerstukken II 2015/I6, 3I OI5, nr. II8, p. 2.

4 I Kamerstukken II 20I5/I6, 34 372, nr. 2.

42 Van der Hof 20I6, p. 55-57.

43 Aanhangsel Handelingen II 2014/15, nr. 933.

44 T. Webb, 'The Brave New World of Cyber Crime Investigation and Prosecution', Nexus 2013-2014, p. 82; M. Chawki en Y. el Shazly, 'Online Sexual Harassment. Issues \& Solutions', Journal of Intellectual Property, Information Technology and E-Commerce Law 2013, p. 76; Conclusie A-G Hofstee, ECLI:NL:PHR:2015:2649, punt 9; Van der Hof 2016, p. 54 .

Kamerstukken II 20I5/I6, 29 279, nr. 300, p. 3. 
is seksuele afpersing 'als zedendelict' niet strafbaar. Hij stelde dat wanneer 'het motief gelegen is in het verkrijgen van geld of goederen, het uiten van frustratie dan wel het schaden in de eer en goede naam, (...) de bestaande wetgeving (...) voldoende (strafrechtelijke) bescherming biedt'. Wanneer het motief echter is gelegen 'in het verkrijgen van meer seksueel materieel dan wel het verkrijgen van (meer) seksuele gunsten' kan er volgens de minister sprake zijn 'van een schending van de lichamelijke en seksuele integriteit en het seksuele zelfbeschikkingsrecht'. Dat roept volgens de minister de vraag op of deze vorm van seksuele afpersing in Titel XIV van het Tweede Boek moet worden opgenomen. ${ }^{46}$ Is de laatstgenoemde vorm van seksuele afpersing op basis van het geldend recht niet strafbaar, zoals de minister suggereert? Daarvoor is nodig de verschillende strafbaarstellingen op basis waarvan sextortion strafbaar zou zijn te onderzoeken. In par. 4 wordt hierop ingegaan.

\section{Sexting en sexchatting}

Het vierde onderwerp dat in de belangstelling staat, is sexting en sexchatting. Sexting is een samenvoeging van 'sex' en 'texting'. In literatuur wordt sexting nogal eens beperkt tot het sturen van foto's en films. ${ }^{47}$ De minister van Veiligheid en Justitie omschrijft sexting als 'het sturen van seksueel getinte berichten of foto's of video's, meestal via de smartphone'. ${ }^{48}$ Deze definitie beperkt sexting niet tot minderjarigen, ook al gaat in de literatuur de meeste aandacht uit naar deze groep van personen. Ten aanzien van adolescenten stelt de minister dat sexting valt 'onder het experimenteergedrag dat in het huidige tijdgewricht past bij adolescenten'. Hij zegt daarmee niet dat dergelijk gedrag niet strafbaar zou moeten zijn, wel dat het kennelijk geen ongewoon verschijnsel is. ${ }^{49}$ Elders stelt hij echter dat 'seksueel materiaal van kinderen' kan worden aangemerkt als kinderpornografie, waarvan het verspreiden strafbaar is. Volgens de minister biedt het huidige wettelijk kader met betrekking tot kinderpornografie voldoende ruimte voor 'maatwerk bij de vervolging' van sexting. ${ }^{50} \mathrm{Bij}$ deze opmerkingen kunnen twee vragen worden gesteld. Allereerst beperken de opmerkingen van de minister zich tot materiaal, waarmee waarschijnlijk foto's en films worden bedoeld. Over seksueel getinte berichten is de minister niet duidelijk. Dat roept de vraag op of deze vorm van sexting strafbaar is. Een tweede vraag betreft de persoon met wie de sexting plaatsvindt. De minister beperkt zich tot 'kinderen', zonder daarbij een leeftijdsgrens te geven. De definitie van sexting maakt geen onderscheid tussen (de leeftijd van) personen.

46 Kamerstukken II 2015/r6, 29 279, nr. 300, p. 9; Aanhangsel Handelingen II 2015/r6, nr. 3249.

47 K. Albury e.a., 'Sexting, Consent and Young People's Ethics: Beyond Megan's Story', Continuum. Journal of Media \& Cultural Studies 2012, p. 463-473; M. Drouin e.a., 'Let's Talk about Sexting, Baby: Computer-Mediated Sexual Behaviors among Young Adults', Computers in Human Behavior 20r3, p. A25-A3o.

48 Kamerstukken II 20I5/I6, 29 279, nr. 300, p. 2; Aanhangsel Handelingen II 20I5/I6, nr. I678. Vgl. Lievens 20I4, p. 254 met verdere verwijzingen en K. Spooner en M. Vaughn, 'Youth Sexting: A Legislative and Constitional Analysis', Journal of School Violence 2016, p. 2 I3.

49 Zie voor ondersteuning hiervan o.a. K.J. Mitchell e.a., 'Prevalence and Characteristics of Youth Sexting: A National Study', Pediatrics 20I2, p. I3-20; E.G. Benotsch e.a., 'Sexting, Substance Use, and Sexual Risk Behavior in Young Adults', Journal of Adolescent Health 2013, p, 307-313; D.S. Strassberg, 'Sexting by High School Students: An Exploratory and Descriptive Study', Archives of Sexual Behavior 2013, p. I5-2I. 
Dat roept de (tweede) vraag op of sexting tussen meerderjarigen op grond van bestaande wetgeving (binnen het Wetboek van Strafrecht) straffeloos is.

De minister onderscheidt sexting van sexchatting. Sexchatting omschrijft hij als 'het op indringende en vergaande seksuele en seksualiserende wijze communiceren via internet'. ${ }^{\mathrm{I}}$ Sexchatting lijkt een bijzondere vorm van sexting te zijn. In beide gevallen gaat het over berichten die gaan over seks en seksualiteit. Sexchatting onderscheidt zich van sexting door de noodzaak van interactie door middel van communicatie. Sexting behoeft geen interactie; het enkele sturen van een seksueel getint bericht levert sexting op. Sexchatting veronderstelt door het gebruik van de term communiceren wel interactie. De communicatie moet indringend en vergaand over seks gaan wil van sexchatting kunnen worden gesproken. Lichtvoetige gesprekken over seks leveren klaarblijkelijk geen sexchatting op. Uit de definitie van sexchatting blijkt ook niet dat tegen de wil van de ander met hem wordt gecommuniceerd..$^{22}$ Waarom dat het geval is, is niet duidelijk. Het in de definitie genoemde verschil tussen seksueel en seksualiserende wijze wordt niet toegelicht; het kan verband houden met de wijze waarop over seks wordt gecommuniceerd: expliciet (seksueel) of impliciet (seksualiserende wijze). Het is denkbaar dat vergaand en indringend en toch impliciet over seks wordt gesproken. Het gebruik van versluierend en door derden niet gebruikt en daarom niet begrepen taalgebruik zou hiervan een voorbeeld kunnen zijn.

De onduidelijkheden in de definitie zouden kunnen worden verklaard doordat feitelijke omschrijving en normatieve waardering in de definitie van sexchatting door elkaar lopen, meer dan het geval is bij bijvoorbeeld sexting. Dan valt wellicht te begrijpen waarom lichtvoetige communicatie over seks niet onder de definitie valt (strafbaarstelling daarvan ligt niet in de rede). Dat geen onderscheid wordt gemaakt tussen vrijwillige of onvrijwillige sexchatting houdt wellicht verband met de inhoud ervan: dat de communicatie indringend en vergaand over seks gaat, vormt op zichzelf een voldoende argument waarom de handeling strafbaar mag worden gesteld. Dat is echter gissen. Al met al is de definitie van sexchatting niet zonder meer helder. Dat maakt de afbakening tussen strafbaar en niet strafbaar gedrag er niet eenvoudiger op.

Net als bij sexting worden in de definitie van sexchatting de leeftijd van dader en slachtoffer niet genoemd. Dat betekent volgens de minister niet dat sexchatting tussen meerderjarigen strafbaar zou moeten worden gesteld. Hij kondigde namelijk enkel aan te onderzoeken of sexchatting met kinderen strafbaar zou moeten worden gesteld. ${ }^{33}$ Dat zou betekenen dat sexchatting op grond van het geldend recht niet strafbaar is. Het is de vraag of deze aanname onder alle omstandigheden houdbaar is. Sexting en sexchatting worden gezamenlijk behandeld in par. 5 van dit preadvies.

5 I Kamerstukken II 2015/I6, 29 279, nr. 300, p. 3.

52 Vgl. J.E. Erni, 'Internet Sex Chatting and "Vernacular Masculinity" among Hong Kong Youth', in: J. Coffey, S. Budgeon en H. Cahill (red.), Learning bodies. The Body in Youth and Childhood Studies, Singapore: Springer 2016, p. 105-106. 
Een onderwerp datal enige jaren in de belangstelling staat, is grooming. Sinds 2010 is grooming als apart seksueel delict strafbaar gesteld (art. 248e Sr). Grooming houdt in het tijdens een chatgesprek met een persoon, jonger dan zestien jaar, doen van een voorstel tot een ontmoeting, met als doel om tijdens die ontmoeting ontuchtige handelingen met die persoon te plegen of kinderpornografische afbeeldingen van hem of haar te vervaardigen, waarbij enige handeling is ondernomen om die ontmoeting te realiseren. In de rechtspraktijk zijn verschillende vragen over de strafbaarstelling van grooming opgeworpen, die de minister ten dele wil adresseren. De eerste is of de persoon aan wie een ontmoeting wordt voorgesteld in werkelijkheid minderjarig moet zijn. In de rechtspraktijk zijn gevallen bekend waarin de ontmoeting werd voorgesteld aan iemand die zich voordeed als een zestienminner maar in werkelijkheid ouder was dan zestien jaar, bijvoorbeeld een ouder, broer of zus of een politieambtenaar, zonder dat de groomer zich hiervan bewust was. Op grond van de huidige wettelijke regeling kan grooming in dat geval niet worden bewezen. De minister heeft een voorstel ingediend dit te veranderen. ${ }^{54}$ Een ander vraagpunt is of poging tot grooming strafbaar is. De rechtspraak is daarover verdeeld, terwijl de wetsgeschiedenis onvoldoende duidelijkheid biedt. Ook hierover heeft de minister getracht duidelijkheid te verschaffen. ${ }^{55}$ Bezien wordt of dat is gelukt. Een derde vraag betreft de uitleg van het bestanddeel 'enige handeling onderneemt gericht op het verwezenlijken van die ontmoeting'. Hier lijkt de Hoge Raad duidelijkheid te hebben gecreëerd. Zijn rechtspraak verdient nadere bestudering. De met de derde vraag samenhangende vraag is wat de verhouding is tussen (poging tot) grooming en poging tot verleiding (art. 45 jo. 248a Sr). De wetgever meende bij de invoering van art. 248e Sr dat hierdoor gedragingen onder de strafwet werden geplaatst die op grond van het toen geldende recht (dat wil zeggen (poging tot) verleiding) niet strafbaar waren. ${ }^{6}$ Onderzocht zal worden of dat een correcte lezing van de rechtspraak betrof. Tevens zal worden onderzocht of het bereik van grooming niet beperkter is dan de strafbaarstelling van poging tot verleiding, en zo ja, of dat consequenties zou moeten hebben voor de reikwijdte van de delictsomschrijving van art. 248 e Sr. De complexe strafbaarstelling van grooming en de gerezen vragen worden behandeld in par. 6 .

Aan het eind van deze subparagraaf kan nog worden gewezen op de zo te noemen 'online ontucht'. Het gaat hier om een breed scala aan gedragingen op het internet waarbij van fysieke aanraking geen sprake is, terwijl de vraag is of zij ontuchtige handelingen of zelfs het seksueel binnendringen van het lichaam kunnen opleveren. In recente literatuur is vrij uitputtend aandacht besteed aan deze lastige categorie van gevallen, zodat zij in dit preadvies buiten beschouwing kan blijven. ${ }^{57}$

Kamerstukken II 20I5/I6, 34 372, nr. 2.

Kamerstukken II 2015/16, 34 372, nr. 3, p. 9I.

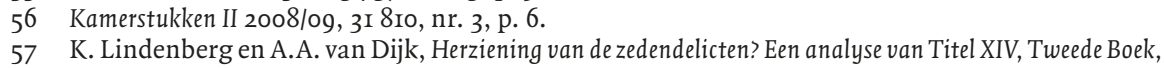
Wetboek van Strafrecht met het oog op samenhang, complexiteit en normstelling, Zutphen: Paris 20I6, p. $62-85$, I $27-132$. 


\section{I.4 Plan van aanpak}

In dit preadvies wordt ingegaan op een aantal onderwerpen dat met seksualiteit en internet verband houdt. Achtereenvolgens worden besproken kinderporno, wraakporno, sextortion, sexting en sexchatting en grooming. De onderwerpen zijn gekozen vanwege de aandacht van de wetgever, die verschillende van de gedragingen al dan niet apart strafbaar wil stellen of de delictsomschrijving van bestaande strafbaarstellingen wil wijzigen. In algemene zin wordt met dit preadvies beoogd inzicht te verschaffen in de versnippering van de wet en de fragmentatie van de in het geding zijnde rechtsbelangen en de uitdagingen die zij met betrekking tot de hiervoor geïntroduceerde fenomenen opleveren. Het formuleren van een antwoord op de vragen die in het voorgaande zijn gesteld, moet bijdragen aan het bereiken van dit doel. De vragen die worden gesteld gaan, voor zover het gaat om kinderpornografie en grooming, om de reikwijdte van de bestaande strafbaarstellingen. Deze vragen worden beantwoord aan de hand van een analyse van wetsgeschiedenis, (feiten)rechtspraak en (Nederlandse) literatuur. Zij worden mede bezien in het licht van de bij de verschillende delicten in het geding zijnde rechtsbelangen, teneinde ook op een niveau dat de concrete strafbaarstellingen overstijgt te kunnen bezien hoe nieuwe op of in verband met internet gepleegde seksuele delicten in het Wetboek van Strafrecht een plaats hebben (en zouden moeten hebben). Tevens wordt aandacht besteed aan de internationale herkomst van deze bepalingen en wordt bezien in hoeverre daarin argumenten kunnen worden gevonden voor de beantwoording van de eerder gestelde vragen. Met betrekking tot sexting, sexchatting, wraakporno en sextortion wordt bezien welke gedragingen onder deze fenomenen kunnen worden geschaard en of (al) deze gedragingen reeds onder bestaande strafbaarstellingen (binnen en buiten Titel XIV van het Tweede Boek) vallen. Ook deze vragen worden aan de hand van wetsgeschiedenis, (feiten)rechtspraak en (Nederlandse) literatuur beantwoord. Omdat we hier te maken hebben met fenomenen waarbij uiteenlopende rechtsbelangen in het geding zijn, passeren in dit preadvies nogal wat strafbaarstellingen de revue. Feitenrechtspraak is in dit preadvies meestal niet gebruikt ter beantwoording van de meer normatieve vragen die in het voorgaande met betrekking tot de te bespreken onderwerpen zijn gesteld..$^{8}$ Wel is zij gebruikt ter illustratie, nu deze rechtspraak zichtbaar maakt hoe een bepaald fenomeen in de rechtspraktijk wordt behandeld.

\section{$2 \quad$ Kinderpornografie}

\section{I Wettelijke regeling en te beschermen rechtsbelangen van art. $240 \mathrm{~b} \mathrm{Sr}$}

De strafbaarstelling van kinderpornografie (art. 24ob lid I Sr) luidt als volgt:

58 Ten behoeve van dit onderzoek is op rechtspraak.nl slechts gezocht naar feitenrechtspraak gewezen na 2010 vanwege de grote hoeveelheid rechtspraak die over de in dit preadvies behandelde onderwerpen is gewezen en het beperkte belang dat in dit preadvies aan feitenrechtspraak is gegeven. In het onderzoek ten behoeve van dit preadvies is vooral (inter)nationale wetgeving, rechtspraak van de Hoge Raad en literatuur bestudeerd. De feitenrechtspraak werd gevonden door te zoeken naar de in dit preadvies behandelde strafbepalingen. De zoekopdracht is gespecificeerd met behulp van termen als 'internet' en 'webcam'. 
'Met gevangenisstraf van ten hoogste vier jaren of geldboete van de vijfde categorie wordt gestraft degene die een afbeelding - of een gegevensdrager, bevattende een afbeelding - van een seksuele gedraging, waarbij iemand die kennelijk de leeftijd van achttien jaar nog niet heeft bereikt, is betrokken of schijnbaar is betrokken, verspreidt, aanbiedt, openlijk tentoonstelt, vervaardigt, invoert, doorvoert, uitvoert, verwerft, in bezit heeft of zich door middel van een geautomatiseerd werk of met gebruikmaking van een communicatiedienst de toegang daartoe verschaft.'

Art. 240b Sr werd in 1986 ingevoerd. ${ }^{59}$ Achtereenvolgende ministers van Justitie hebben zich (bij verschillende wetswijzigingen) uitgelaten over de rechtsgoederen en -belangen die met deze bepaling worden beschermd. Vooropstaat de bescherming van minderjarigen tegen seksueel misbruik..$^{60}$ Meer in het algemeen moeten zij worden beschermd tegen gedrag dat 'schadelijk is voor de jeugdige, òf omdat het tot die gedraging brengen al schadelijk is, òf vanwege de publikatie daarvan'. ${ }^{6}{ }^{6}$ Met de strafbaarstelling van virtuele kinderpornografie in 2002 werd art. $240 \mathrm{obr}$ ook gerechtvaardigd met het oog op 'het voorkomen van schade als gevolg van het in omloop brengen van beeldmateriaal dat seksueel misbruik suggereert' ${ }^{62}$ Niet de daadwerkelijke schadelijkheid ligt aan strafbaarstelling van virtuele kinderpornografie ten grondslag. Veeleer gaat het om de potentiële schade die aan echte kinderen kan worden toegebracht door personen die reeds door virtuele kinderpornografie seksueel worden geprikkeld. De idee is dat confrontatie met virtuele kinderpornografie de dader zal brengen tot het willen vervaardigen, bezitten, enzovoort van afbeeldingen van echte kinderen. Dat laatste gedrag is schadelijk voor kinderen. De wetgever wijst ook op het bestaan van een 'subcultuur' die niet kan worden geaccepteerd. ${ }^{6}$ Dit argument wordt soms in verband gebracht met schade: kinderpornografie is schadelijk omdat het een subcultuur in stand houdt met een markt voor kinderpornografie. In andere gevallen staat het argument op zichzelf. Dan lijkt het een meer ethisch argument tegen kinderpornografie.

Kinderpornografie wordt ook in internationale overeenkomsten afgekeurd en daarin soms beschouwd als schadelijk voor kinderen. ${ }^{64}$ De opkomst van informatie- en communicatietechnologie wordt nogal eens genoemd als rechtvaardiging voor een ruime omschrijving van de strafbaarstelling van kinderpornografie. Zij brengt specifieke vragen met zich mee ten aanzien van de interpretatie van bestanddelen van art. 240b Sr. Drie bestanddelen worden hierna besproken: 'afbeel-

59 Wet van 3 juli 1985 , Stb. 385 .

6o Kamerstukken I I984/85, I5 836, nr. 6rb, p. 2; Handelingen II 25 oktober I984, p. 924.

6 I Kamerstukken II I994/95, 23 862, nr. 5, p. 9; Kamerstukken II 200I/02, 27 745, nr. 6, p. 8, II, I6; Kamerstukken I 200I/02, 27 745, nr. 299b, p. 3; Kamerstukken II 1994/95, 23 862, nr. 5, p. 9-Io.

62 Kamerstukken II 2000/or, 27745 , nr. 3, p. 4.

63 Kamerstukken II 200I/02, 27 745, nr. 6, p. 9; Kamerstukken I 2001/02, 27 745, nr. 299b, p. 2; Kamerstukken I 2009/Io, 3I 808 (RI872), nr. C, p. 8.

64 Verdrag inzake de rechten van het kind met bijbehorend Facultatief Protocol inzake de verkoop van kinderen, kinderprostitutie en kinderpornografie van 20 november I989, Trb. I990, 46; Facultatief Protocol van 25 mei 2000, Trb. 200I, 63; Verdrag van de Raad van Europa inzake de bescherming van kinderen tegen seksuele uitbuiting en seksueel misbruik van 25 oktober 2007 , Trb. 2008, 58; Kaderbesluit 2004/68/JBZ van de Raad van de Europese Unie ter bestrijding van seksuele uitbuiting van kinderen en kinderpornografie, PbEU 2004, L 13/44; Richtlijn 2011/93/ EU van het Europees Parlement en de Raad van 13 december 201 I ter bestrijding van seksueel misbruik en seksuele uitbuiting van kinderen en kinderpornografie, en ter vervanging van Kaderbesluit 2004/68/JBZ van de Raad, PbEU 20II, L 335/I. 
ding', 'schijnbaar betrokken' en 'zich door middel van een geautomatiseerd werk of met gebruikmaking van een communicatiedienst de toegang daartoe verschaffen'. Andere bestanddelen, zoals opzet, zijn voor een goed begrip van art. 240b Sr weliswaar relevant, maar eigen onderzoek naar recente rechtspraak leverde weinig nieuws op ten opzichte van de bevindingen van eerder onderzoek. ${ }^{65} \mathrm{Om}$ die reden worden niet alle bestanddelen van art. 240b Sr besproken.

\subsection{Afbeelding}

Al enige tijd wordt de vraag gesteld of beelden die via een webcam te volgen zijn als afbeeldingen in de zin van onder meer art. 24ob Sr kunnen worden beschouwd. ${ }^{66}$ Het met behulp van een webcam beelden volgen wordt 'live streaming' genoemd ${ }^{67}$ Wanneer deze beelden niet door de kijker worden bewaard of het programma er niet op is gericht deze beelden te bewaren (zoals snapchat), is het de vraag of van een afbeelding kan worden gesproken. De rechtspraak hieromtrent heeft vooral betrekking op art. $240 \mathrm{a} \mathrm{Sr} ;{ }^{68} \mathrm{zij}$ is ook voor art. $240 \mathrm{ob}$ (en art. 240) Sr relevant.

Een afbeelding wordt door de wetgever onderscheiden van een voorwerp en een geschrift. ${ }^{69}$ Voorbeelden van afbeeldingen zijn: foto's, films, videoclips, tekeningen of hologrammen. De term is techniek-neutraal: hieronder worden begrepen 'allerlei visuele middelen waarin de moderne techniek voorziet'. $7^{\circ}$ Een afbeelding moet volgens Noyon-Langemeijer-Remmelink direct 'een realiteit oproepen' bij degene die de afbeelding aanschouwt. Deze omschrijving wordt overigens gebruikt om foto's en films van een tekening en beschrijving te onderscheiden, niet om daarmee aan te geven dat live beelden op een webcam ook een afbeelding zijn. ${ }^{71}$ De minister van Veiligheid en Justitie spreekt van afbeeldingen wanneer 'die als zodanig kunnen worden ervaren'.$^{2}$ De vraag of van een afbeelding slechts sprake is, wanneer deze een zekere duurzaamheid heeft, lijkt op grond van deze omschrijving negatief te moeten worden beantwoord. ${ }^{73}$ Het oproepen van een realiteit

65 L. Stevens en E.J. Koops, 'Opzet op de harde schijf: criteria voor opzettelijk bezit van digitale kinderporno', DD 2009/5I.

66 Lindenberg en Van Dijk 20r6, p. I73-I79.

67 Het gaat in het kader van kinderpornografie bijvoorbeeld om echte kinderen die seksuele gedragingen verrichten voor een webcam waarnaar door andere personen wordt gekeken, al dan niet in hetzelfde land. Zie M. van der Bruggen, 'Een beschouwing van de ontwikkeling van het internet en cybercriminaliteit en de gevolgen hiervan voor de internationale bestrijding van kinderporno', Tijdschrift voor Criminologie 2015, p. 252. Enkele jaren geleden ontstond discussie over de straf baarstelling van virtuele kinderporno in virtuele werelden. In dat geval gaat het om avatars met het uiterlijk van een minderjarige die seksuele gedragingen verricht met een avatar met een volwassen uiterlijk. Zie over de strafbaarheid van dergelijk gedrag J. Kokswijk en A.R. Lodder, Virtuele werelden en regulering, Den Haag: Rathenau Instituut 2008, p. 36; J. Brasem en B.W. Schermer, 'Virtuele kinderpornografie in virtuele werelden: strafrechtelijk sanctioneren?', Tijdschrift voor Internetrecht 2008, p. I46-I5I.

68 Lindenberg en Van Dijk 20I6, p. I6I-I66.

69 Vgl. Kamerstukken II I979/80, I5 836, nr. 3, p. 7.

70 Tweede interimrapport van de adviescommissie zedelijkheidswetgeving, 's-Gravenhage: Staatsuitgeverij I973, p. 23; Th.A. de Roos en L.W. Wissink, 'Uitingsdelikten op het internet en strafrechtelijke repressie', NJB I996, p. I729.

7I Noyon-Langemeijer-Remmelink, Het Wetboek van Strafrecht, Deventer: Kluwer (losbl.), aant. 2 bij art. 240.

72 Kamerstukken II 2015/I6, 29 279, nr. 287, p. 26.

73 De minister van Veiligheid en Justitie is over dit punt overigens niet zonder meer duidelijk. Elders stelde hij dat een kinderpornografische afbeelding (op het internet) 'immers in feite niets 
kan eenmalig zijn en hoeft niet vatbaar te zijn voor herhaling. Zo lijken verschillende rechtbanken het bestanddeel afbeelding in ieder geval te interpreteren. Dit zou betekenen dat webcambeelden als afbeeldingen kunnen worden beschouwd. Daarbij wordt in die rechtspraak gewezen op de bedoeling van de wetgever: bescherming van 'personen beneden de leeftijd van zestien jaar tegen ongewenste beïnvloeding die het gevolg kan zijn van de confrontatie met dergelijke beelden'. Dat zou aan een ruime interpretatie van het bestanddeel afbeelding niet in de weg staan. ${ }^{74}$ Het Hof Leeuwarden oordeelde echter in een arrest uit 2012 dat een zekere duurzaamheid nodig is om van een afbeelding te kunnen spreken. Beelden die niet worden opgeslagen, zijn volgens dit hof geen afbeeldingen. ${ }^{75}$ Deze uitleg is met betrekking tot art. $240 \mathrm{O} \mathrm{Sr}$ (en art. 240 en $24 \mathrm{ob} \mathrm{Sr}$ ), hoewel verklaarbaar gelet op de door de wetgever gegeven voorbeelden, aanvechtbaar. Nergens in de wetsgeschiedenis staat namelijk vermeld dat de wetgever duurzaamheid verlangt. Hij gebruikte duurzame afbeeldingen telkens als voorbeeld (en de praktijk gaat veelal over duurzame afbeeldingen). Als we er echter van uitgaan dat de wetgever de term afbeelding techniek-neutraal hanteerde (en hierin het advies van de adviescommissie zedelijkheidswetgeving volgde), dan staat dat aan een ruime interpretatie van het bestanddeel niet in de weg. Daarbij werd vooral gedacht in termen van onmiddellijkheid. Zo bezien kunnen 'live stream' beelden vallen onder het bestanddeel afbeelding.

Vanuit wetsystematisch oogpunt ligt een ruime uitleg van het bestanddeel afbeelding echter niet zonder meer voor de hand. ${ }^{6}$ In het geval een minderjarige zich voor een webcam toont en daarbij seksuele gedragingen verricht, van expliciet seksuele aard of die strekken tot het opwekken van seksuele prikkeling, kunnen deze gedragingen onder het bereik van andere seksuele delicten vallen. Daarbij kan worden gedacht aan art. $246 \mathrm{Sr}$, dat volgens de regering ook strafbaar stelt 'het dwingen van een persoon om ontuchtige handelingen met zichzelf te verrichten' en art. $248 \mathrm{a}$, dat ook strafbaar stelt het bewegen van een minderjarige 'tot het plegen van seksuele handelingen zonder lijfelijke betrokkenheid van een ander'. ${ }^{7}$ Volgens Lindenberg en Van Dijk is de uitleg van art. $246 \mathrm{Sr}$ restrictiever dan de uitleg van de Hoge Raad, ${ }^{78}$ wat een argument vormt om de betekenis van afbeeldingen in art. 24ob Sr niet verder te verruimen. Verwijzing naar de door art. 24ob

anders [is] dan een digitale vastlegging van seksueel misbruik van een minderjarige' (Kamerstukken II 20I4/I5, 3I OI5, nr. II2, p. 4). De term vastlegging suggereert een zekere duurzaamheid.

74 Rb. 's-Gravenhage 27 september 20I2, ECLI:NL:RBSGR:20I2:BX8650; Rb. Assen 20 december 20II, ECLI:NL:RBASS:20II:BU9972; Rb. Leeuwarden Io mei 20II, ECLI:NL:RBLEE:20II:BQ4I76.

75 Hof Leeuwarden 27 maart 20I2, NJFS 20I2/II9. Zie ook Rb. Midden-Nederland II juni 20I3, ECLI:NL:RBMNE:2013:2777.

76 In de art. I39f en 44Ib Sr komt afbeelding voor in het bestanddeel 'een afbeelding vervaardigt'. Daaronder moet 'mede moet worden verstaan het waarnemen van een persoon met een technisch hulpmiddel, waarbij een afbeelding op bijvoorbeeld een monitor tot stand komt, doch zonder dat de afbeelding wordt vastgelegd' (Kamerstukken II 200I/oI, 27732 , nr. 3, p. 8). Op grond hiervan zou kunnen worden gesteld dat afbeelding wel omvat 'live stream' beelden. Omdat de wetgever deze ruime uitleg slechts hanteert bij het bestanddeel 'een afbeelding vervaardigt' en deze ruime omschrijving elders ontbreekt, althans niet consistent wordt volgehouden, is echter maar de vraag of deze uitleg ook kan worden gehanteerd bij het bestanddeel 'afbeelding'.

77 Kamerstukken II 200I/or, 27 745, nr. 3, p. 7.

78 Lindenberg en Van Dijk 20I6, p. 80-8I, onder verwijzing naar het door de Hoge Raad ontwikkelde interactiecriterium waarbij lijfelijk contact niet wordt vereist. Zie Lindenberg en Van Dijk 20r6, p. 62-77. 
Sr beschermde rechtsgoederen is op zichzelf echter niet bijzonder sterk, nu die bescherming ook door art. 246 en 248 a Sr wordt geboden (terwijl de strafmaxima van deze delicten gelijk of zelfs hoger liggen dan het strafmaximum van art. 240b lid I Sr). Het argument wint echter aan kracht wanneer daaraan wordt toegevoegd dat in art. 240b Sr gedragingen van minderjarigen voor een webcam als seksuele gedragingen kunnen worden gekwalificeerd, zonder dat sprake is van de gedragingen die in art. 246 en 248a Sr worden vereist (namelijk dwingen, respectievelijk opzettelijk bewegen). Art. 24ob Sr kan met andere woorden een aanvulling op beide bepalingen vormen in het geval er wel sprake is van seksuele gedragingen, maar niet blijkt van dwang met bedreiging met geweld of enige feitelijkheid (vereist voor art. $246 \mathrm{Sr}$ ) of het opzettelijk bewegen door middel van verleidingsmiddelen (vereist voor art. 248a Sr). ${ }^{79}$ Wanneer het bestanddeel afbeelding te restrictief wordt uitgelegd, lijkt een leemte in de wet te ontstaan, die gelet op de in het geding zijnde rechtsbelangen (in het bijzonder de bescherming van kinderen), niet zonder meer kan worden aanvaard. ${ }^{80}$

Biedt internationale regelgeving steun voor een ruime uitleg van het bestanddeel afbeelding? Richtlijn 20II/93/EU maakt in de Nederlandse vertaling (en enkele andere vertalingen) onderscheid tussen materiaal, afbeeldingen en weergave (art. 2(c)). Of daartussen daadwerkelijk verschil bestaat, is niet duidelijk. Weergave kan synoniem zijn voor afbeelding (de Duitse vertaling van de Richtlijn maakt tussen afbeelding en weergave geen onderscheid) en daarmee kan zijn bedoeld iets dat in beeld is gebracht. Kan met weergave ook weergeven zijn bedoeld en dus niet alleen betrekking hebben op iets dat in beeld is gebracht, maar ook iets dat in beeld is? Hoewel overweging 9 dat niet lijkt uit te sluiten, schijnt dat toch niet het geval te zijn. In de eerste plaats wordt in overweging I2 van de preambule van de Richtlijn onderscheid gemaakt tussen seksueel misbruik en seksuele uitbuiting van kinderen op internet en kinderpornografie. Gelet hierop lijkt van kinderpornografie

79 Ik heb mij afgevraagd of hiervoor in de rechtspraak van het EHRM argumenten kunnen worden gevonden. Dit Hof vereist strafbaarstelling van 'ernstige feiten' waarbij expliciet wordt gewezen op verkrachting (van minderjarigen) en feitelijke aanranding van de eerbaarheid of ontucht met minderjarigen. Van ernstige feiten worden onderscheiden feiten die een potentiële bedreiging voor het fysieke en morele welzijn van een minderjarige vormen en lichte feiten die mogelijk inbreuk maken op de psychologische integriteit van de ander. Ook deze feiten vereisen een effectieve remedie, maar strafbaarstelling wordt door het Hof bij de laatste categorie niet vereist. Onder de laatste categorie valt het heimelijk filmen van naakte personen. Zie EHRM I2 november 2013, appl.nr. 5786/08 (Söderman/Zweden), EHRC 2014/36, m.nt. Lindenberg. Niet duidelijk is of seksuele gedragingen door een minderjarige voor een webcam een licht feit behelzen, of een potentiële bedreiging vormen voor het fysieke en morele welzijn van een minderjarige. Dat laatste lijkt het geval te zijn als de minderjarige een doelwit wordt voor toenaderingen door pedofielen. Als daarmee wordt bedoeld daadwerkelijke fysieke toenadering, dan lijkt het erop dat enkel via de webcam kijken naar minderjarigen die seksuele gedragingen verrichten zonder die minderjarige te willen toenaderen niet strafrechtelijk hoeft te worden aangepakt. Het Hof lijkt op dit punt nog zoekende, zie EHRM 3I maart 20I6, nr. 30808/II (A, B en C/Letland), EHRC 2016/I63, zodat op basis van 's Hofs rechtspraak geen eenduidig antwoord kan worden geformuleerd.

80 Ook art. 248c Sr biedt geen oplossing. Uit de wetsgeschiedenis blijkt dat het aanwezig zijn bij het door een achttienminner plegen van ontuchtige handelingen moet worden beperkt tot fysieke aanwezigheid bij een seksshow. Lindenberg en Van Dijk (20I6, p. I66-r7I) merken op dat de bepaling hierdoor wellicht te beperkt wordt uitgelegd in het licht van Europese verplichtingen. Het ziet er dan ook naar uit dat de wetgever zijn inzicht omtrent art. 248c Sr moet wijzigen. Een wijziging van de delictsomschrijving lijkt echter niet nodig (vgl. over gewijzigd inzicht M.J. Borgers, Bij nader inzien (afscheidsrede VU Amsterdam), Deventer: Kluwer 20I6). 
geen sprake te kunnen zijn als seksuele gedragingen van kinderen via 'live stream' worden weergegeven. Het tonen van minderjarigen via live streambeelden moet namelijk strafbaar zijn gesteld als seksueel misbruik of uitbuiting. In de tweede plaats staat in overweging I 8 van de preambule dat door middel van informatie- en communicatietechnologie welbewust toegang verschaffen tot kinderpornografie strafbaar moet worden gesteld. Daarbij wordt het volgende gesteld: 'De betrokkene is pas aansprakelijk wanneer hij van plan is een website te bezoeken waarop kinderpornografie beschikbaar is en tevens weet dat dergelijke afbeeldingen daar te vinden zijn. Er moeten geen straffen worden opgelegd wanneer iemand onopzettelijk op een website met kinderpornografie terechtkomt.' Deze overweging laat in het midden wat onder afbeeldingen moeten worden verstaan. Op basis van de Richtlijn valt dus niet met zekerheid te zeggen of live stream beeld onder het begrip afbeeldingen valt. ${ }^{8 \mathrm{r}}$

Lindenberg en Van Dijk wijzen erop dat met de toevoeging van het hierna nog te bespreken bestanddeel 'zich door middel van een geautomatiseerd werk of met gebruikmaking van een communicatiedienst de toegang daartoe verschaft' in de literatuur vrij stellig is aangenomen dat ook 'live stream' kijken naar kinderpornografie strafbaar is op grond van art. $240 \mathrm{o} \mathrm{Sr}{ }^{82} \mathrm{Zij}$ vonden één vonnis dat de vraag oproept of het bestanddeel afbeelding wel ruim kan worden uitgelegd bij het zich toegang verschaffen door middel van een geautomatiseerd werk of communicatiedienst, maar niet bij de andere gedragingen in art. $240 \mathrm{~b} \mathrm{Sr} .{ }^{83}$ Dat zou betekenen dat hetzelfde bestanddeel in één delictsomschrijving twee betekenissen heeft. Uit de wetsgeschiedenis kan echter niet worden opgemaakt dat de wetgever met de invoering van het bestanddeel 'zich door middel van een geautomatiseerd werk of met gebruikmaking van een communicatiedienst de toegang daartoe verschaft' het bestanddeel afbeelding een dubbele betekenis heeft willen geven. Iets anders lijkt ook niet eenvoudig te verenigen met het legaliteitsbeginsel, in het bijzonder het lex-certagebod.

In rechtspraak van de Hoge Raad over de betekenis van 'afbeelding van een seksuele gedraging' wijst hij erop dat daaronder ook moet worden verstaan 'een afbeelding die weliswaar niet een gedraging van expliciet seksuele aard in de hiervoor aangegeven zin toont, maar die, gelet op de wijze waarop zij is totstandgekomen

8I Het Cybercrimeverdrag van de Raad van Europa van 23 november 200I, Trb. 2002, I8 stelt met betrekking tot afbeeldingen dat het moet gaan om 'materiaal' ('materials') dat bepaalde nader genoemde handelingen 'uitbeeldt' ('depicts') (art. 9 lid 2). Uitbeelden zou ook 'live stream' kunnen, maar de term materiaal wijst op iets dat een duurzamer karakter heeft. Het Cybercrimeverdrag lijkt dus niet zonder meer steun te bieden voor een ruime uitleg van de term afbeeldingen, maar verbiedt hem evenmin.

82 Lindenberg en Van Dijk 20I6, p. I76. De Nationaal Rapporteur Mensenhandel (Kinderpornografie. Eerste rapportage van de Nationaal rapporteur, Den Haag: BNRM 20II, p. 5I) wees erop dat vroeger het kijken naar kinderpornografie strafbaar was door aan te nemen dat door het kijken tijdelijke internetbestanden waren aangemaakt die op die manier wel als afbeeldingen konden worden gekwalificeerd. Deze constructie wijst er wel op dat een afbeelding een zeker duurzaam karakter moet hebben. Uit de wetsgeschiedenis valt echter niet zonder meer af te leiden of de wetgever het bestanddeel afbeelding na verloop van tijd een andere betekenis heeft gegeven, zodat deze opmerking ook als een bevestiging kan worden gezien dat voor een afbeelding enige duurzaamheid moet worden verlangd.

83 Lindenberg en Van Dijk 20I6, p. I77. 
eveneens strekt tot het opwekken van seksuele prikkeling, ${ }^{84}$ Deze omschrijving zegt primair iets over de inhoud van het bestanddeel 'seksuele gedraging'. ${ }^{85}$ De gebruikte bewoordingen, in het bijzonder 'de wijze van totstandkoming', wekken de indruk dat volgens de Hoge Raad van een afbeelding slechts sprake is wanneer die tot stand gekomen is, dat wil zeggen wanneer er een resultaat ligt. Dat resultaat hoeft wellicht niet tastbaar te zijn, maar moet wel een zekere duurzaamheid hebben, doordat het als bestand is opgeslagen op een of ander medium, en tastbaar kan worden gemaakt. Omdat de uitspraak van de Hoge Raad echter op iets anders betrekking had (zie par. 2.6), moet aan deze overweging wellicht niet al te veel waarde worden gehecht bij de beoordeling van de vraag of live stream beeld ook als een afbeelding kan worden gekwalificeerd. Het voorgaande laat echter zien dat eraan kan worden getwijfeld of live stream beeld zonder meer als afbeelding kan worden gekwalificeerd, de soms stellige overtuiging van het tegendeel in de literatuur ten spijt.

\subsection{Schijnbaar betrokken}

Het bestanddeel 'schijnbaar betrokken' is in 2002 aan art. 24ob Sr toegevoegd. Met dit bestanddeel werd ook virtuele kinderpornografie strafbaar. Niet elke virtuele kinderporno viel volgens de wetgever onder het bestanddeel 'schijnbaar betrokken'. Het moest gaan om een 'realistische afbeelding' die 'op het eerste gezicht' niet is 'te onderscheiden van afbeeldingen van een echt kind'. ${ }^{86}$ Naar de letter van de wet valt een niet-realistische afbeelding van een niet-bestaand kind echter wel onder art. 24ob Sr. Een realistische afbeelding vereist de wet namelijk niet. In de Aanwijzing kinderpornografie van het Openbaar Ministerie uit 2oro stond dat ook afbeeldingen die 'niet evident levensecht zijn' onder het bereik van art. 24ob Sr dienen te vallen. ${ }^{87}$ Alleen onmiskenbaar creatieve en kunstzinnige afbeeldingen moesten hiervan worden uitgezonderd. In feitenrechtspraak is deze uitleg soms gevolgd, soms niet. ${ }^{88}$

De Hoge Raad hield de opvatting van het hof dat een 'realistische afbeelding van een niet-bestaand kind' zo moet worden uitgelegd dat 'de afbeelding niet van echt is te onderscheiden' voor juist. ${ }^{89}$ Het hof was in de zaak die leidde tot deze uitspraak van de Hoge Raad tot de conclusie gekomen dat 'de afbeelding niet van echt is te onderscheiden' omdat de afgebeelde personen 'geen echte kinderen' waren en dat 'voor de gemiddelde kijker (...) aanstonds blijkt dat het gaat om gemanipuleerde afbeeldingen'. ${ }^{\circ}$ Deze overwegingen werden door de Hoge Raad in de kernoverweging weliswaar niet herhaald, de conclusie die daaruit werd ge-

84 HR 7 december 20IO, NJ 20II/8I, m.nt. Schalken.

85 Vgl. HR ro juni 20I4, NJ 20I4/3I6.

86 Kamerstukken II 200I/oI, 27 745, nr. 6, p. 9, I2, I4; Kamerstukken I 200I/02, 27 745, nr. 299 b, p. 2.

87 Aanwijzing kinderpornografie (art. 240 b Sr) van I november 20I0, Stcrt. 20I0, I9I2I.

88 L. van den Berge en W. de Zanger, 'Net echt. Of toch niet? Over virtuele kinderporno', Ars Aequi 2OII, p. 773 .

89 HR I2 maart 2013, NJ 2013/403, m.nt. Borgers. De opvatting die het Openbaar Ministerie in de (vorige) Aanwijzing kinderpornografie huldigde, bleek dus onjuist. In de Aanwijzing kinderpornografie van I8 april 20I6, Stcrt. 2016, I9415 komt de uit de vorige Aanwijzing geciteerde passage niet meer voor.

90 Hof 's-Hertogenbosch I4 april 20II, ECLI:NL:GHSHE:20II:BQII79 (i.c. ging het om tekeningen van minderjarigen die seksuele gedragingen verrichtten met meerderjarigen). 
trokken werd door de Hoge Raad wel als juist beoordeeld. Dit wekt de indruk dat voor het antwoord op de vraag of sprake is van een realistische afbeelding van een niet-bestaand kind, het kind zo echt mogelijk moet zijn afgebeeld. Dat wordt bepaald door wat aanstonds blijkt. Het arrest riep ten minste drie nieuwe vragen op: wanneer is een afbeelding niet van echt te onderscheiden, wanneer kan worden gesproken van 'aanstonds' en bij wie moet dat blijken?

In een zaak waarin het ging om schilderijen waarop minderjarige jongens naakt waren geschilderd, soms met engelenvleugels op de rug, beantwoordde de Hoge Raad een aantal van deze vragen. Of sprake is van een niet-realistische afbeelding van een niet-bestaand kind mag volgens de Hoge Raad niet worden bepaald door de wijze waarop het kind is weergegeven. Een 'geschilderde realistische weergave van een seksuele gedraging waarbij iemand die kennelijk de leeftijd van achttien jaar nog niet heeft bereikt', kan onder de delictsomschrijving van art. 240b Sr vallen. Niet-realistische elementen op een afbeelding (of: 'een niet-werkelijkheidsgetrouwe weergave van een kind') hebben 'niet zonder meer tot gevolg dat de afbeelding van het kind als geheel niet kan worden aangemerkt als een realistische afbeelding', die niet van echt is te onderscheiden..$^{91}$ Indien de seksuele gedraging realistisch is geschilderd, is een afbeelding kennelijk niet van echt te onderscheiden.

De Hoge Raad laat in het midden wie de kijker is bij wie 'aanstonds' moet blijken dat sprake is van een realistische afbeelding. Of hij een gemiddelde kijker, een ervaren kijker of een kind is, is niet duidelijk. Dat het hof op grond van eigen waarneming van de afbeeldingen tot een bepaalde conclusie kwam, doet vermoeden dat de kijker geen deskundige hoeft te zijn. Evenmin lijkt te kunnen worden aangenomen dat met de kijker een kind wordt bedoeld. De uitspraak lijkt te impliceren dat de kijker toch wat langer moet kijken voordat hij zijn oordeel velt. Immers, niet-realistische elementen leiden er 'niet zonder meer' toe dat de afbeelding niet van echt is te onderscheiden. Ook de omstandigheid dat deze niet-realistische elementen 'ondergeschikte onderdelen' van de afbeelding moeten zijn, vraagt enige bestudering van de afbeelding voordat een oordeel wordt geveld.

Een nog niet beantwoorde vraag is of de overwegingen uit het arrest van de Hoge Raad zich beperken tot geschilderde seksuele gedragingen of ook betrekking kunnen hebben op cartoons waarop een kind niet-werkelijkheidsgetrouw is afgebeeld maar de seksuele gedraging wel. Dat lijkt niet bij voorbaat uitgesloten, ook al werd in het arrest benadrukt dat het in casu om schilderijen ging. Vanuit het beschermde rechtsbelang valt er wel wat voor te zeggen dergelijke afbeeldingen (inclusief cartoons) te verbieden. Niet alleen lijkt dat uit het oogpunt van bescherming van minderjarigen en het voorkomen van schade te kunnen worden aanvaard, ook het belang van het bestrijden van een pedofiele subcultuur maakt het meer voor de hand liggend dat bezit (etc.) van afbeeldingen van niet-bestaande kinderen die realistisch afgebeelde seksuele gedragingen verrichten strafbaar is..$^{92}$

9I HR 8 december 20I5, NJ 20I6/95, m.nt. Keijzer.

92 Vgl. M.J. Borgers in zijn annotatie onder HR I2 maart 2013, NJ 2013/403. 


\subsection{Toegang verschaffen met behulp van een geautomatiseerd werk of communicatiedienst}

In de delictsomschrijving van art. 24ob Sr gaat het om een afbeelding van een seksuele gedraging van een persoon die kennelijk de leeftijd van achttien jaar nog niet heeft bereikt. Verschillende gedragingen met een afbeelding zijn strafbaar gesteld, waaronder het zich daartoe toegang verschaffen met behulp van een geautomatiseerd werk (bijvoorbeeld een smartphone) of een communicatiedienst (denk aan Google, maar ook via voor de meeste mensen verborgen communicatiediensten op het deep of dark web). ${ }^{93}$ Dit bestanddeel is toegevoegd omdat kinderpornografische afbeeldingen ook worden bekeken zonder dat iemand ze in bezit heeft. De wetgever wilde voorkomen dat 'personen die zich bijvoorbeeld met gebruik van versleutelingstechnieken of besloten computernetwerken toegang verschaffen tot kinderpornografie, bij afwezigheid van gedownload materiaal op de eigen computer, niet strafrechtelijk kunnen worden vervolgd'. ${ }^{94}$ Hiermee werd volgens de wetgever niet het enkele bekijken van kinderpornografie met behulp van een webcam strafbaar gesteld. Het gaat om het zich toegang verschaffen tot afbeeldingen. Dat vereist een actieve, opzettelijke handeling. Voor het bewijs van opzet volstaat voorwaardelijk opzet (het bewust aanvaarden van de aanmerkelijke kans dat met behulp van een communicatiedienst of geautomatiseerd werk toegang wordt verschaft tot kinderpornografische afbeeldingen), wat het bewijs vergemakkelijkt. Het lijkt er ook op dat de gedraging resultaat moet hebben gehad: de toegang tot afbeeldingen is verschaft, dat wil zeggen gerealiseerd. Daarmee is niet gezegd dat de afbeeldingen ook daadwerkelijk moeten zijn bekeken. De term verschaffen laat dat in het midden. ${ }^{95}$ In recente feitenrechtspraak werd aangenomen dat toegang verschaffen niet hoeft in te houden dat de afbeeldingen zijn bekeken of in bezit zijn genomen. ${ }^{6}{ }^{6}$ Iets anders zou de toegevoegde waarde van dit bestanddeel ten opzichte van bezit sterk verminderen.

Poging tot toegang verschaffen (art. $45 \mathrm{Sr}$ ) wordt door de wet niet uitgesloten. Wanneer reeds sprake is van toegang verschaffen zonder dat wordt geëist dat de afbeeldingen zijn bekeken of in bezit zijn genomen, is voor strafbare poging maar in zeer beperkte mate ruimte. Het ligt niet voor de hand het enkele surfen op internet strafbaar te stellen. Op een zoekmachine zoektermen invoeren waarmee toegang kan worden verschaft tot kinderporno, terwijl vervolgens geen toegang wordt verkregen tot de betreffende website, zou een strafbare poging kunnen opleveren, wanneer het voornemen is geweest om daadwerkelijk kinderpornografische afbeeldingen in bezit te nemen door deze (vanaf die website) te downloaden. Aangezien voorwaardelijk opzet in art. $24 \mathrm{ob} \mathrm{Sr}$ voldoende is voor het aannemen van opzet kan met behulp van de poging vrij snel strafrechtelijke aansprakelijkheid worden aangenomen. De mogelijkheid om vrijwillig terug te treden (art. 46b $\mathrm{Sr}$ ) is naar het zich laat aanzien door de aard van de strafbaar gestelde gedraging beperkt.

93 Daarover V. Ciancaglini e.a., Below the Surface. Exploring the Deep Web, TrendLabs Research Paper 2015.

94 Kamerstukken II 2008/o9, 3I 8Io, nr. 3, p. 3, 4.

95 Vgl. Kamerstukken II 2008/og, 3I 8Io, nr. 3, p. 4.

96 Rb. Noord-Nederland 23 oktober 2015, ECLI:NL:RBNNE:2015:6139; Hof Arnhem-Leeuwarden I8 maart 20I5, ECLI:NL:GHARL:2015:20I6. 


\subsection{Consensueel bezitten van kinderpornografie}

Het maken en verzenden van naaktfoto's zou meer dan geregeld plaatsvinden onder adolescenten. Deze vorm van sexting is volgens de minister van Veiligheid en Justitie niet strafbaar, omdat zij valt 'onder het experimenteergedrag dat in het huidige tijdgewricht past bij adolescenten'. ${ }^{97}$ De straffeloosheid van dit gedrag blijkt ook uit Richtlijn 20II/93/EU en parlementaire stukken over art. 240b Sr. $9^{8} \mathrm{De}$ tekst van art. 240b Sr laat echter geen ruimte open voor een dergelijke nuancering. De zeventienjarige vriend die met zijn smartphone een afbeelding van een seksuele gedraging van zijn zestienjarige vriendin maakt en vervolgens in bezit heeft, vervult de delictsomschrijving van art. $240 \mathrm{~b}$ Sr. De zestienjarige vriendin die een afbeelding van een seksuele gedraging van zichzelf makt en deze naar haar vriend stuurt, verspreidt kinderporno en is naar de letter van de wet eveneens strafbaar. De Hoge Raad heeft echter recentelijk overwogen dat de delictsomschrijving van art. $240 \mathrm{o} \mathrm{Sr}$, gelet op de parlementaire geschiedenis, 'te ruim is geredigeerd'. Niet helemaal duidelijk is of daarmee de gehele delictsomschrijving wordt bedoeld, of alleen de delictsomschrijving voor zover die ziet op het bezit door adolescenten en jong volwassenen van kinderpornografische afbeeldingen van adolescenten. Gelet op de aan het arrest ten grondslag liggende zaak, de daarin aangehaalde wetsgeschiedenis en een eerder arrest van de Hoge Raad, ${ }^{99}$ lijkt deze overweging te zijn beperkt tot bezit. ${ }^{100}$ De Hoge Raad oordeelde vervolgens dat in het licht van 'de concrete gedraging van de verdachte, de leeftijd van de betrokkenen, de instemming van de betrokkenen en het ontbreken van enige aanwijzing voor een risico van verspreiding van de afbeelding(en) onder anderen dan de betrokkenen', het aan de strafrechter is

'om - ook al is voldaan aan alle bestanddelen van art. $240 \mathrm{obr}$ - in het soort gevallen dat is genoemd in de wetsgeschiedenis, aan de hand van factoren als hiervoor genoemd de vraag onder ogen te zien of het gedrag van de verdachte, alle omstandigheden in aanmerking genomen, van dien aard is dat het moet worden gekwalificeerd als het in die bepaling als misdrijf tegen de zeden strafbaar gestelde feit, en ingeval die vraag

97 Kamerstukken II 20I5/I6, 29 279, nr. 300, p. 2, Io. Zie ook Kamerstukken 200o/or, 27 745, nr. 6, p. I5I7; Kamerstukken II 2001/02, 27 745, nr. I4, p. I7; Kamerstukken I 2001/02, 27 745, nr. 299b, p. 4-5.

98 Zie Richtlijn 20II/93/EU van het Europees Parlement en de Raad van I3 december 2oII ter bestrijding van seksueel misbruik en seksuele uitbuiting van kinderen en kinderpornografie, en ter vervanging van Kaderbesluit 2004/68/JBZ van de Raad, PbEU 29II, L 335/I (preambule, punt 20); Kamerstukken II 2000/oI, 27 745, nr. 3, p. 6; Kamerstukken II 2000/0I, 27 745, nr. 6, p. I5-I6.

99 HR I8 november 20I4, NJ 20I5/2II, m.nt. Rozemond, in welke zaak het ging om een meisje dat vrijwillig afbeeldingen van seksuele gedragingen van haarzelf aan verdachte ter beschikking stelde, die deze vervolgens verspreidde naar een derde, echter zonder toestemming van het meisje. Onder verwijzing naar de wetsgeschiedenis liet de Hoge Raad het arrest van het hof in stand. Dat had onder meer overwogen dat het in art. 24ob Sr opgenomen verbod ook tot doel heeft minderjarigen tegen zichzelf te beschermen.

Ioo Richtlijn 20II/93/EU sluit overigens onder omstandigheden uit dat het vervaardigen van bepaalde (in de Richtlijn omschreven) afbeeldingen strafbaar is (art. 5 lid 8). Omdat de Hoge Raad niet verwijst naar de Richtlijn en in de wetsgeschiedenis niet naar deze bepaling wordt verwezen, valt niet met zekerheid aan te nemen of de Hoge Raad ook het vervaardigen onder de hierna geformuleerde kwalificatie-uitsluitingsgrond laat vallen. 
ontkennend wordt beantwoord, de verdachte te ontslaan van alle rechtsvervolging op de grond dat het bewezenverklaarde niet een strafbaar feit oplevert'. ${ }^{\text {'or }}$

Het ligt voor de hand dat, zoals ook uit de door de Hoge Raad in zijn arrest aangehaalde wetsgeschiedenis blijkt, de vraag of een gedraging een strafbaar feit oplevert, reeds door het Openbaar Ministerie bij zijn vervolgingsbeslissing zal moeten worden gesteld en beantwoord.

Uit het zojuist weergegeven citaat kan worden afgeleid dat niet alle factoren bepalend zijn voor het oordeel of de gedragingen een strafbaar feit opleveren. Er wordt namelijk niet gesproken over 'de' factoren. Wel moeten volgens de Hoge Raad alle omstandigheden in aanmerking worden genomen. Wat die omstandigheden zijn, blijft in het ongewisse. Gedacht kan worden aan de plaats waar de afbeeldingen werden gemaakt, hoeveel afbeeldingen werden gemaakt, of bij het maken ervan meer dan twee personen aanwezig waren, of het maken onder invloed van drank of drugs plaatsvond, of ten tijde van de gedraging sprake was van een affectieve relatie tussen de bezitter van de afbeelding en de persoon die is afgebeeld en dergelijke. Met alle omstandigheden wordt duidelijk gemaakt dat het geheel van uit de wettige bewijsmiddelen blijkende omstandigheden moet worden betrokken bij het oordeel of er sprake is van een strafbaar feit. De verhouding tussen factoren en omstandigheden is niet helemaal duidelijk, terwijl het ook de vraag is of bepaalde factoren zwaarder wegen dan andere of ten opzichte van elkaar gelijkwaardig zijn. Het ligt echter voor de hand dat de leeftijd van de betrokkenen en met name het geringe leeftijdsverschil en het ontbreken van enige aanwijzing voor het risico van verspreiding van de afbeelding(en) belangrijke factoren zijn. Hoe groter het leeftijdsverschil, hoe eerder van een ongelijkwaardige verhouding sprake is, hoe minder snel een beroep op de kwalificatie-uitsluitingsgrond succesvol zal zijn. Of de relatie ten tijde van het maken van de afbeeldingen effectiefwas, zal in dat geval minder relevant zijn. Hetzelfde geldt wanneer het risico van verspreiding aanwezig is. Overigens is het de vraag wanneer daarvan sprake is. Levert het hebben van dergelijk materiaal op een smartphone of computer die is aangesloten op internet niet al een risico van verspreiding op? Op welk moment is van een dergelijk risico sprake en wie bepaalt dat? Het bestaan van instemming door de afgebeelde persoon lijkt een niet al te relevante factor. Wanneer de instemming onder invloed van drugs of drank tot stand is gekomen, zou bijvoorbeeld niet van instemming mogen worden gesproken. In meer algemene zin wordt er in rechtspraak op gewezen dat jeugdigen tegen zichzelf in bescherming moeten worden genomen. Instemming hoeft dan ook aan strafbaarheid niet in de weg te staan. ${ }^{102}$ Instemming kan naar het zich laat aanzien slechts een rol spelen wanneer ook andere factoren (met een groter gewicht) aanwezig zijn. Uit de overwegingen van de Hoge Raad kan overigens worden afgeleid dat één factor niet voldoende is; het moet gaan om een samenspel van factoren en alle omstandigheden teneinde te bepalen of sprake is van een strafbaar feit.

IOI HR 9 februari 2016, NJ 20r6/257, m.nt. Rozemond. In hoeverre de geformuleerde oplossing van de Hoge Raad voor dit probleem gelukkig is gekozen, gaat het bestek van dit preadvies te buiten, ook omdat voor het antwoord op deze vraag de doorwerking van Europees recht moet worden betrokken.

IO2 Vgl. HR 30 maart 20I0, NJ 20I0/376, m.nt. Keijzer; EHRM 30 augustus 20II, nr. 37334/08 (G./Verenigd Koninkrijk), EHRC 20II/167, m.nt. Ten Voorde. 
Op basis van voorgaande valt niet te verwachten dat het niet kunnen kwalificeren van de bewezenverklaarde gedragingen als het in art. 240b Sr opgenomen strafbare feit snel zal worden aangenomen. De in het geding zijnde rechtsbelangen lijken ook niet te rijmen met een ruime toepassing van de kwalificatie-uitsluitingsgrond.

\title{
2.6 Andere relevante pornografiebepalingen
}

Naast art. 24ob Sr zijn enkele andere strafbaarstellingen in het Wetboek van Strafrecht relevant voor de bestrijding van pornografie op het internet, waarbij minderjarigen zijn betrokken, in het bijzonder art. 240 en $240 \mathrm{a}$ Sr. Beide bepalingen worden in deze subparagraaf besproken.

Art. 240 Sr: ongevraagde en ongewilde confrontatie met pornografie

Art. 240 Sr luidt:

\begin{abstract}
'Met gevangenisstraf van ten hoogste twee maanden of geldboete van de derde categorie wordt gestraft hij die weet of ernstige reden heeft om te vermoeden dat een afbeelding of voorwerp aanstotelijk voor de eerbaarheid is en die afbeelding of dat voorwerp: $\mathrm{I}^{\circ}$. op of aan een plaats, voor het openbaar verkeer bestemd, openlijk tentoonstelt of aanbiedt;

$2^{\circ}$. aan iemand, anders dan op diens verzoek, toezendt.'
\end{abstract}

Met de strafbaarstelling van art. $240 \mathrm{Sr}$ wordt beoogd mensen te beschermen tegen ongevraagde en ongewilde confrontatie met pornografie. Ongevraagde en ongewilde (de wetgever spreekt in samenvattende zin van onverhoedse) confrontatie met dergelijk materiaal vormt 'een zodanige inbreuk (...) op de vrijheid van de persoon, dat er aanleiding bestaat die inbreuk met behulp van de strafwet tegen te gaan'. ${ }^{103}$ Voor strafbaarheid is nodig dat deze confrontatie plaatsvindt 'op of aan een plaats, voor het openbaar verkeer bestemd'. Dat zijn 'die openbare plaatsen, welke men in het normale verkeer betreedt'. Plaatsen 'waarvan men niet kan zeggen dat de bezoeker er geheel argeloos met de vertoning wordt geconfronteerd', zijn geen openbare plaatsen. ${ }^{104}$ Kan internet als openbare plaats worden beschouwd? De minister van Justitie heeft dat met betrekking tot art. 240 Sr nooit met zoveel woorden gesteld. Lodder stelt dat het 'beschikbaar stellen van informatie op het internet (...) het voor een ieder waar ook ter wereld met een internetaansluiting mogelijk [maakt] om van die informatie kennis te nemen. Dit geeft in de kern de toegankelijkheid van informatie op internet weer: de hele wereld kan erbij.' ${ }^{105}$ Op grond hiervan kan internet (en dus een internetpagina), voor zover deze voor eenieder toegankelijk is, als een openbare plaats worden beschouwd. ${ }^{106}$ Wat voor informatie geldt, geldt gelet op het voorgaande ook voor afbeeldingen die

I03 Kamerstukken II I979/80, I5 836, nrs. I-3, p. 9.

I04 Kamerstukken II I979/80, I5 836, nrs. I-3, p. Io.

I05 A.R. Lodder in zijn annotatie onder HvJ EU I3 februari 20I4, C-466/I2 (Svensson e.a.), Computerrecht $2014 / 75$.

Io6 Hof's-Gravenhage 8 juni 2004, ECLI:NL:GHSGR:20I4:AP7974. 
daarop beschikbaar zijn gesteld. Het op internet openlijk tentoonstellen of aanbieden van afbeeldingen die aanstotelijk voor de eerbaarheid zijn, lijkt strafbaar. Het via internet toezenden van dergelijke afbeeldingen aan iemand, anders dan op diens verzoek, is volgens de minister van Justitie op grond van art. $240 \mathrm{Sr}$ in ieder geval strafbaar. ${ }^{107}$

Deze gedragingen zijn slechts strafbaar wanneer de afbeeldingen aanstotelijk voor de eerbaarheid zijn. Met aanstotelijk wordt tot uitdrukking gebracht dat de seksuele handeling strijdig is met 'de hier te lande heersende zeden'. ${ }^{\text {108 }}$ Andere omschrijvingen kunnen als een verduidelijking hiervan worden beschouwd en typeren de seksuele handeling als 'op onbehoorlijke wijze kwetsend voor het geslachtelijk schaamtegevoel', ${ }^{\text {109 }}$ tegen het 'normaal ontwikkeld schaamtegevoel'rio of 'aantasting van het sexuele schaamtegevoel, het kuisheidsgevoel van anderen'. ${ }^{\text {III }}$ Of sprake is van gedragingen in strijd met de heersende zeden moet volgens de Hoge Raad worden bepaald 'door de bij een belangrijke meerderheid van het Nederlandse volk levende opvattingen'. ${ }^{112}$ Het schaamtegevoel van de betrokken persoon (het slachtoffer dat onverhoeds met de afbeelding wordt geconfronteerd) is niet doorslaggevend. De wetgever heeft de omschrijving van de Hoge Raad overgenomen, ${ }^{\mathrm{II}}$ en gaf de rechter de vrijheid de invulling ervan aan te passen als de opvattingen van het Nederlandse volk wijzigen.

Is een afbeelding met een handeling die aanstotelijk is voor de eerbaarheid iets anders dan een afbeelding van een seksuele gedraging? Deze vraag is van belang nu de gedragingen van art. 240 en $240 \mathrm{~b}$ Sr elkaar tot op zekere hoogte overlappen. Ook in art. 24ob Sr zijn openlijk tentoonstellen, aanbieden en aan een ander toezenden (dat als een vorm van verspreiden kan worden beschouwd) strafbaar gesteld. Hiervoor bleek dat aanstotelijkheid voor de eerbaarheid duidt op een bepaalde handeling. Om te bepalen of er ten aanzien van het bestanddeel afbeelding verschillen bestaan tussen art. 240 en $240 \mathrm{~b}$ Sr is het van belang te kijken naar de inhoud van de seksuele gedraging. De Hoge Raad verstaat onder een afbeelding van een seksuele gedraging in de zin van art. 240b Sr:

'een afbeelding van een gedraging van expliciet seksuele aard, zoals die aan de hand van de afbeelding zelf kan worden vastgesteld, waaronder begrepen het op zinnenprikkelende wijze tonen van de geslachtsdelen of de schaamstreek. Het gaat hierbij om een gedraging die reeds door haar karakter strekt tot het opwekken van seksuele prikkeling. Voorts ziet art. 240b Sr op een afbeelding die weliswaar niet een gedraging van expliciet seksuele aard de hiervoor aangegeven zin toont, maar die, gelet op de wijze waarop zij is totstandgekomen eveneens strekt tot het opwekken van seksuele

I07 Kamerstukken II 2009/Io, 32 I23 VI, nr. 79, p. 8. Zie ook A.L.J. Janssens en A.J. Nieuwenhuis, Uitings-delicten, Deventer: Kluwer 20II, p. 353.

Io8 HR ig november $1974, \mathrm{NJ}$ 1975/I33.

Io9 A-G Jörg in zijn conclusie voor HR 5 december 2000, ECLI:NL:HR:2000:AA825; HR I juni I976, NJ I976/506; NLR aant. I bij art. 239.

IIo HR I december I97I, NJ I97I/374, m.nt. Bronkhorst.

III J.M. van Bemmelen en W.F.C. van Hattum, Hand- en leerboek van het Nederlandse strafrecht. Deel II Bijzondere delicten (door J.M. van Bemmelen), 's-Gravenhage/Arnhem: Martinus Nijhoff/Gouda Quint I954, p. 443-444.

II2 HR ig november I974, NJ I975/I33.

II3 Kamerstukken II I979/80, I5 836, nrs. I-3, p. 9. 
prikkeling. Hierbij kan het gaan om een afbeelding van iemand in een houding of omgeving die weliswaar op zichzelf en in andere omstandigheden "onschuldig" zouden [sic] kunnen zijn, maar die in het concrete geval een onmiskenbaar seksuele strekking heeft. ${ }^{\text {II }}$

De strekking is in beide gevallen van belang om te bepalen of er sprake is van een seksuele gedraging. Soms valt uit de gedragingen zelf evident die strekking af te leiden, soms valt uit het concrete geval af te leiden of de gedraging een onmiskenbaar seksuele strekking heeft. Dat lijkt een vrij objectieve beoordeling (wat zijn de feiten?), in tegenstelling tot aanstotelijk voor de eerbaarheid, dat een normatief oordeel behelst (wat vindt de meerderheid van het Nederlandse volk ervan?). Levert dit verschillen in beoordeling op? Als we de relevante rechtspraak over art. 24ob Sr bekijken, valt dat te bezien. In een zaak waar op platen collages waren gemaakt van foto's waarbij telkens (enkel) de naakte gestalte van jonge meisjes waren weergegeven, oordeelde het hof dat - gelet op de wijze waarop de collages tot stand waren gekomen - deze strekken tot het opwekken van seksuele prikkeling en een onmiskenbaar seksuele strekking hebben. De Hoge Raad deed de zaak met art. 8I Wet RO af. ${ }^{15}$ Het lijkt geen stap te ver aan te nemen dat dergelijke afbeeldingen ook aanstotelijk voor de eerbaarheid zijn.

In de gevallen waarin de feitenrechter tot vrijspraak oordeelde, omdat er geen sprake was van een afbeelding van een seksuele gedraging blijkt het volgende. In een aantal gevallen was voor het oordeel of sprake was van een seksuele gedraging de context waarbinnen de foto was genomen van belang. Niet alle foto's van blote billen van kinderen of van kinderen die tijdens een spelletje bepaalde poses aannemen hebben een onmiskenbaar seksuele strekking, zelfs al werden op de foto's soms uitdagende houdingen door de gefotografeerde naakte minderjarige aangenomen. Uit rechtspraak blijkt dat de context deels wordt bepaald door wat op de afbeeldingen zelf zichtbaar was. Relevant blijken ook de omstandigheden waaronder de afbeeldingen werden vervaardigd. ${ }^{\mathrm{I1}}$ Het is maar de vraag of de rechter tot een ander oordeel was gekomen indien hij het criterium dat de afbeelding aanstotelijk voor de eerbaarheid is, had moeten gebruiken. Dat houdt ermee verband dat voor de beoordeling van de strekking van een gedraging op de achtergrond kan meespelen op basis van welke normen dat gedrag moet worden beoordeeld. Of een afbeelding een seksuele strekking heeft die onmiskenbaar is, kan niet uitsluitend op basis van de bewezenverklaarde feiten worden beoordeeld. Die feiten moeten worden gewogen en gewaardeerd tegen de achtergrond van in de samenleving geldende normen om te kunnen spreken van afbeeldingen met een onmiskenbaar seksuele strekking. Dat zou betekenen dat het verschil met aanstotelijk voor de eerbaarheid niet bijzonder groot is. Bij het ontbreken van een seksuele gedraging vormt art. $240 \mathrm{Sr}$ daarom geen alternatief voor art. $240 \mathrm{~b} \mathrm{Sr}$. Dat is anders wanneer

II4 HR 7 december 20I0, NJ 20II/8I, m.nt. Schalken.

II5 HR I8 november 2014, ECLI:NL:HR:2014:3304. Zie voor andere gevallen o.a. HR 3I november 2012, ECLI:NL:HR:2012:BX9599 (HR: art. 8I Wet RO); Hof Den Haag 17 november 2015, ECLI:NL: GHDHA:2015:3257; Rb. Noord-Nederland 22 september 2015, ECLI:NL:RBNNE:2015:4446; Rb. Midden-Nederland I3 september 2013, ECLI:NL:RBMNE:2013:4678; Rb. Utrecht 3I maart 20II, ECLI:NL:RBUTR:20II:BQ0756.

II6 Rb. Rotterdam 7 oktober 2015, ECLI:NL:RBROT:2015:7175; Hof Arnhem-Leeuwarden 30 maart 2015, ECLI:NL:GHARL:2015:2434. 
de leeftijd van de afgebeelde persoon niet duidelijk (en een beroep op afwezigheid van alle schuld denkbaar) is, maar de aanstotelijkheid van de afbeelding wel kan worden vastgesteld.

Art. 240a Sr: voor minderjarigen schadelijk te achten afbeelding verstrekken, aanbieden of vertonen

Art. 240a Sr luidt:

'Met gevangenisstraf van ten hoogste een jaar of geldboete van de vierde categorie wordt gestraft hij die een afbeelding, een voorwerp of een gegevensdrager bevattende een afbeelding waarvan de vertoning schadelijk is te achten voor personen beneden de leeftijd van zestien jaar, verstrekt, aanbiedt of vertoont aan een minderjarige waarvan hij weet of redelijkerwijs moet vermoeden dat deze jonger is dan zestien jaar.'

Art. 240a Sr werd ingevoerd ter vervanging van art. 240bis (oud) Sr dat onder meer strafbaar stelde het aan een minderjarige aanbieden of blijvend of tijdelijk afstaan van een afbeelding die aanstotelijk voor de eerbaarheid is. De memorie van toelichting behandelde de invoering van art. 240a Sr onder het kopje 'De bescherming van de jeugd', waarmee de bedoeling van de bepaling duidelijk lijkt. In de toelichting wordt aangegeven waartegen de jeugd moet worden beschermd. Dat is niet tegen de schade die door afbeeldingen of voorwerpen (en later ook: gegevensdragers bevattende een afbeelding) wordt veroorzaakt, maar tegen het 'risico van schade'. ${ }^{17}$ De wetgever baseerde zich op de adviescommissie zedelijkheidswetgeving die tot het oordeel kwam dat niet kon worden vastgesteld dat (pornografische) afbeeldingen de jeugd schaden. ${ }^{\mathrm{II} 8}$ Wel meende zij dat een risico van schade kon worden aangenomen. Dat risico van schade wordt in art. 240a Sr tot uitdrukking gebracht in het bestanddeel 'schadelijk is te achten' op te nemen. Met schadelijk is te achten wordt niet verlangd dat de rechter vaststelt dat de afbeelding schadelijk was voor de minderjarige; voldoende is dat deze 'mogelijke schade' 'door kennisneming van pornografie in de vorm van afbeeldingen of voorwerpen' vaststelt. Tegen mogelijke schade moeten minderjarigen worden beschermd, om te voorkomen dat misbruik wordt gemaakt van 'de zwakkere positie' van 'de opgroeiende mens'. In de parlementaire stukken wordt ook gesproken over het voorkomen van 'nadelige beïnvloeding van de ontwikkeling van de jeugdige'. ${ }^{\text {I9 }}$ Beoogd wordt dus een ongestoorde (seksuele) ontwikkeling van het kind naar volwassenheid te verzekeren. Er wordt van uitgegaan dat het risico bestaat dat die ontwikkeling wordt belemmerd wanneer het kind wordt geconfronteerd met pornografisch materiaal. Het voorgaande wijst er niet alleen op dat bewijs van schade in een strafzaak niet hoeft te worden geleverd. Tevens wijst het ten aanzien van het 'risico van schade' op een zekere objectiviteit. Of de minderjarige zich beschadigd voelt (of dat derden vinden dat het tonen van pornografische afbeeldingen schadelijk is), is irrelevant voor het bewijs van 'schadelijk is te achten'. ${ }^{20}$ Dat kan voor jongeren die met weinig

II7 Kamerstukken II I979/80, I5 836, nrs. I-3, p. 7-8.

II8 Adviescommissie zedelijkheidswetgeving I977, p. I2.

II9 Kamerstukken II I980/8I, I5 836, nr. 6, p. 4; Adviescommissie zedelijkheidswetgeving I977, p. I2.

I20 Lindenberg en Van Dijk 2016, p. I62. 
gêne het eigen naakte lichaam tonen (en daarbij vrij ver durven te gaan om zo veel mogelijk viewers te krijgen) tot onbegrip leiden. Het kan ook voor de rechter lastig zijn, die zich met een uitspraak omwille van het kind onbedoeld verwijdert van het kind. Dat geldt overigens ook voor andere hiervoor besproken gevallen.

Art. 240a Sr stelt strafbaar 'de onmiddellijke confrontatie van een geïndividualiseerde jeugdige met het beeldmateriaal' maar ook de middellijke confrontatie door 'het in handen van een jongere stellen van gegevensdragers waarop schadelijk beeldmateriaal is vastgelegd'. ${ }^{21}$ Het gaat in beide gevallen om een directe interactie van de dader met een minderjarige. De dader, die overigens zelf ook nog geen zestien jaar oud hoeft te zijn, toont een (andere) zestienminner een foto of film die schadelijk is te achten voor de laatstgenoemde (en dus mogelijk ook voor zichzelf), of geeft aan hem een dvd, smartphone of tablet met daarop afbeeldingen die voor hem schadelijk zijn te achten. Uit de eis van directe interactie volgt dat internetpagina's met schadelijk te achten afbeeldingen buiten het bereik van art. $240 a$ Sr vallen. ${ }^{122}$ Via internet is, hoewel daarvoor een gegevensdrager nodig is, onmiddellijke confrontatie natuurlijk wel mogelijk. Met behulp van sociale media worden afbeeldingen aan minderjarigen verstrekt, aangeboden of vertoond. In dat geval gaat het om een onmiddellijke confrontatie met behulp van een gegevensdrager. Het onderscheid dat de wet maakt tussen middellijke en onmiddellijke confrontatie komt hier te vervallen. Dat de confrontatie via een gegevensdrager plaatsvindt, doet er niet aan af dat de afbeelding onmiddellijk wordt getoond. De rechtspraak heeft er in ieder geval geen moeite mee dergelijke gedragingen onder art. 240a Sr te scharen en neemt, in het geval de (directe) interactie via sociale media (Facebook, WhatsApp, Instagram en dergelijke) plaatsvond, alle bestanddelen van art. 240a Sr op in de bewezenverklaring. ${ }^{\mathrm{I23}}$ De afbeeldingen kunnen van de dader zelf zijn, of van derden die zelfs minderjarig kunnen zijn. In dat geval lijkt er sprake van een zekere overlap met art. $240 \mathrm{~b} \mathrm{Sr}$, indien de handelingen seksuele gedragingen opleveren. Het voordeel van het gebruik van art. $240 \mathrm{a}$ Sr ten opzichte van art. $240 \mathrm{~b}$ Sr is dat bij art. $240 \mathrm{O}$ Sr geen bewijs hoeft te worden geleverd van een seksuele gedraging waarbij een minderjarige (schijnbaar) is betrokken.

\section{Seksuele afpersing}

\section{I Vormen van seksuele afpersing in het strafrecht}

Afbeeldingen van seksuele gedragingen van een (minderjarige of meerderjarige) persoon kunnen (door een bekende van die persoon) op internet worden geplaatst of verspreid met als doel om de afgebeelde persoon af te persen. Het motief om af te persen kan 'gelegen zijn in het verkrijgen van meer seksueel materiaal dan wel het verkrijgen van (meer) seksuele gunsten. (...).' Ook is denkbaar dat de afperser

I2I Kamerstukken II I999/2000, 2684 I, nr. 3, p. Io.

I22 Lindenberg en Van Dijk 20I6, p. I6I, I64.

I23 Naast de door Lindenberg en Van Dijk (20I6, p. I63-I64) genoemde rechtspraak, kan worden gewezen op o.a. Rb. Noord-Nederland ro mei 20I6, ECLI:NL:RBNNE:20I6:2258; Rb. MiddenNederland 23 maart 20I6, ECLI:NL:RBMNE:20I6:I485; Rb. Noord-Nederland I december 2015, ECLI:NL:RBNNE:20I5:55I3. 
geld of andere (virtuele) goederen wil, zoals afbeeldingen met seksuele handelingen van de persoon die wordt afgeperst. ${ }^{124}$ De minister van Veiligheid en Justitie is van mening dat gedwongen worden tot (meer) seksuele gunsten 'een schending van de lichamelijke en seksuele integriteit en het seksuele zelfbeschikkingsrecht' is. Hij laat onderzoeken of dergelijk gedrag apart strafbaar moet worden gesteld als seksueel delict (in Titel XIV dus). ${ }^{125}$ De minister liet na te vermelden of seksuele afpersing door een ander te dwingen tot (meer) seksuele gunsten reeds strafbaar is op basis van bestaande seksuele delicten. Indien hij daarmee wilde aangeven dat dit niet het geval is, dan lijkt die opvatting op het eerste gezicht juist. De afpersingshandelingen leveren naar het zich laat aanzien bijvoorbeeld geen voorbereidingshandelingen voor deze misdrijven op. Bepaalde middelen om af te persen (zoals afbeeldingen van seksuele gedragingen) kunnen wellicht (ook) worden beschouwd als voorwerpen als bedoeld in art. $46 \mathrm{Sr}$, toch ligt het minder voor de hand dat zij, in de termen van de Hoge Raad, zelfs met het gebruik ervan 'naar hun uiterlijke verschijningsvorm' zijn 'bestemd tot' het begaan van verkrachting of feitelijke aanranding van de eerbaarheid, ook omdat de aan een ander via internet getoonde voorwerpen er niet op gericht zijn om daarmee die ander te verkrachten of aan te randen. ${ }^{126}$

Seksuele afpersing met een ander doel dan het verkrijgen van (meer) seksuele gunsten is naar Nederlands recht strafbaar. Van strafbare afpersing is naar Nederlands recht sprake, wanneer een ander door bedreiging met geweld wordt gedwongen goederen af te staan of gegevens ter beschikking te stellen (art. 317 Sr). Een gedraging waardoor een ander door bedreiging met smaad(schrift) of openbaring van een geheim wordt gedwongen goederen af te staan of gegevens ter beschikking te stellen, levert het strafbare feit afdreiging op (art. $3{ }^{18} \mathrm{Sr}$ ). ${ }^{127}$ Voor beide strafbaarstellingen geldt dat de gedraging moet zijn gepleegd met het oogmerk om zichzelf of een ander wederrechtelijk te bevoordelen. ${ }^{\mathrm{I} 28}$ Bevoordelen heeft in beide bepalingen dezelfde ruime betekenis. Niet nodig is dat het voorwerp of de gegevens voor een ieder enige economische waarde heeft. ${ }^{129}$ De Hoge Raad heeft geoordeeld dat het gebruik van middelen waarmee 'de grenzen van het maatschappelijk betamelijke' verre overschreden wordt, voldoende is om het oogmerk van

I24 Bijv. Hof Amsterdam I7 september 20I5, ECLI:NL:GHAMS:20I5:4348; Rb. Midden-Nederland 3I januari 20I4, ECLI:NL:RBMNE:20I4:409; Rb. Noord-Holland II juli 20I3, ECLI:NL:RBNHO: 20I3:9066; Rb. Breda 8 maart 20II, ECLI:NL:RBBRE:20II:BP7or4; Rb. 's-Gravenhage Io november 20I0, ECLI:NL:RBSGR:20I0:BO3596.

I25 Kamerstukken II 2015/16, 29 279, nr. 300, p. 9.

I26 Weliswaar hoeven de voorwerpen die zijn aangetroffen niet te worden gebruikt om het grondfeit te begaan, het lijkt mij te ver gaan om van strafbare voorbereidingshandelingen te spreken in het geval iemand voorwerpen voorhanden heeft waarmee hij het begaan van het grondfeit wellicht heeft bevorderd, maar niet de bedoeling had om met die voorwerpen het grondfeit te begaan. Vgl. HR 27 mei 20I4, NJ 20I4/338, m.nt. Rozemond.

I27 Bijv. Rb. Den Haag 27 september 20I5, ECLI:NL:RBDHA:20I5:III44; Rb. Noord-Nederland 2 december 20I4, ECLI:NL:RBNNE:20I4:6093; Rb. Utrecht 26 september 20I2, ECLI:NL:RBUTR: 20I2:BX8548; Rb. Utrecht I3 april 20I2, ECLI:NL:RBUTR:20I2:BW43II.

I28 Uit feitenrechtspraak blijkt dat soms ook wordt gekozen voor dwang (art. $284 \mathrm{Sr}$ ). Dat heeft als voordeel dat het oogmerk van wederrechtelijke bevoordeling niet hoeft te worden bewezen, terwijl voor dwang ook voldoende is bedreiging met een feitelijkheid. Zo kan bijvoorbeeld worden gedreigd met het onthullen van wat later onwaarheden blijken te zijn. Zie Rb. Noord-Nederland 2 december 20I4, ECLI:NL:RBNNE:20I4:6093.

I29 NLR, aant. 4 bij art. 3I7; T\&C Sr, aant. I3c bij art. 3 I7. 
wederrechtelijke bevoordeling vast te stellen. ${ }^{130}$ Poging tot afpersing of afdreiging is strafbaar. Voorbereiding van afpersing is eveneens strafbaar. Het voorhanden hebben van een naaktfoto van een derde die bestemd is om een ander te dwingen bijvoorbeeld geld af te staan, kan strafbare voorbereiding van afpersing opleveren.

Met betrekking tot het in art. 3I7 en 3I8 Sr opgenomen bestanddeel 'ter beschikking stellen van gegevens' is de vraag of onder gegevens ook kunnen worden verstaan het (opnieuw) voor een webcam verrichten van seksuele handelingen. In dat geval is ook het verkrijgen van bepaalde seksuele gunsten reeds strafbaar als een vorm van afpersing of afdreiging. Het Hof Arnhem heeft een aantal jaren geleden gesuggereerd dat dergelijke gedragingen gegevens zijn als bedoeld in de wet. Het verklaarde namelijk het volgende bewezen:

'dat de verdachte met het oogmerk om zich of een ander wederrechtelijk te bevoordelen, door bedreiging met smaad, smaadschrift of openbaring van (een) geheim(en), een persoon genaamd [naam aangeefster] te dwingen om seksuele handelingen te verrichten voor een webcam of camera, althans opnames van zichzelf te sturen naar verdachte, opzettelijk met voormeld oogmerk aan die [naam aangeefster] in 2007 opgenomen beelden van haar, waarbij zij bij zichzelf seksuele handelingen verrichte, heeft toegezonden en/of waarbij hij heeft geëist dat die [naam aangeefster] opnieuw voor een webcam of camera seksuele handelingen moest verrichten, omdat verdachte anders de in 2007 opgenomen beelden zou sturen naar vrienden van die [naam aangeefster] ${ }^{13 \mathrm{I}}$

Art. 8oquinquies verstaat onder gegevens 'iedere weergave van feiten, begrippen of instructies, op een overeengekomen wijze, geschikt voor overdracht, interpretatie of verwerking door personen of geautomatiseerde werken'. Het lijkt erop dat volgens het Hof Arnhem beelden op een webcam kunnen worden beschouwd als een weergave van feiten (op een gegevensdrager, zoals een personal computer, smartphone of tablet) die geschikt zijn voor overdracht (en interpretatie) door personen.

Wanneer iemand wordt gedwongen tot het plegen van (meer) offline 'hands-on' seksuele handelingen met een ander, ${ }^{132}$ is van (poging tot) afpersing of bedreiging geen sprake. Er kan in dat geval niet worden gesproken van afgifte van enig goed, het aangaan van een schuld, het tenietdoen van een inschuld of van het ter beschikking stellen van gegevens. Dat betekent niet dat deze vorm van seksuele afpersing op dit moment straffeloos is. Zij wordt in feitenrechtspraak namelijk beschouwd als een vorm van dwang (art. $284 \mathrm{Sr}$ ). Daaronder valt het bedreigen met enige feitelijkheid (die er bijvoorbeeld in bestaat naaktfoto's openbaar te maken via sociale media) teneinde een ander ertoe te dwingen met die ander seks te hebben. ${ }^{\mathrm{I} 33} \mathrm{Bij}$ dwang wordt enig resultaat verlangd. Het uitblijven van enig effect kan betekenen dat er sprake is van een poging tot dwang, bijvoorbeeld wanneer de bedreiging wel is geuit en door het slachtoffer is ontvangen, maar het slachtoffer vervolgens niet

I30 HR 9 februari I97I, NJ I972/I, m.nt. Bronkhorst. Vgl. HR I4 februari I995, NJ I995/426.

I3I Hof Arnhem 8 februari 20I2, ECLI:NL:GHARN:20I2:BV8I28. Het bewezenverklaarde kon volgens het hof overigens niet worden gekwalificeerd, omdat de tenlastelegging was gebaseerd op de delictsomschrijving van art. 3I8 Sr die pas na de feiten in werking was getreden.

I32 Zie voor deze term Nationaal Rapporteur Mensenhandel 20II, p. 4I-44.

I33 Rb. Arnhem I5 februari 20II, ECLI:NL:RBARN:20II:BP44II. Vgl. Rb. Arnhem 28 december 20I2, ECLI:NL:RBARN:20I2:BY76II; Rb. Maastricht I4 april 20I0, ECLI:NL:RBMAA:20Io:BMIII7. 
heeft gedaan wat van hem werd verlangd. ${ }^{134}$ Uit het voorgaande kan, mede gelet op de nodige feitenrechtspraak, al met al worden geconcludeerd dat verschillende vormen van seksuele afpersing onder het bereik van bestaande strafbaarstellingen kunnen worden gebracht.

\subsection{Verleiding als voorfase van seksuele afpersing}

Seksuele afpersing werd in de vorige subparagraaf in verband gebracht met door bedreiging iemand dwingen iets te doen. Een ander ergens toe te bewegen kan ook op subtielere wijze plaatsvinden. In een dergelijk geval kan van seksuele afpersing niet worden gesproken, omdat deze terminologie omwille van conceptuele helderheid, beperkt moet worden tot verschillende vormen van dwang, zoals die in het Wetboek van Strafrecht op nogal wat plaatsen terug te vinden zijn en, afhankelijk van de omstandigheden waaronder dwang plaatsvond of het doel van dwang, uiteenlopende rechtsbelangen beogen te beschermen. Andere manieren om een ander te brengen tot seksuele handelingen zijn te vinden in de Zedentitel, bijvoorbeeld in art. 248a Sr. Dat luidt:

'Hij die door giften of beloften van geld of goed, misbruik van uit feitelijke verhoudingen voortvloeiend overwicht of misleiding van een persoon waarvan hij weet of redelijkerwijs moet vermoeden dat deze de leeftijd van achttien jaren nog niet heeft bereikt, opzettelijk beweegt ontuchtige handelingen te plegen of zodanige handelingen van hem te dulden, wordt gestraft met gevangenisstraf van ten hoogste vier jaren of geldboete van de vierde categorie.'

In het licht van de thematiek van deze paragraaf en omdat art. 248a Sr enkele keren terugkeert in dit preadvies, behoeven de bestanddelen bewegen, misbruik van uit feitelijke verhoudingen voortvloeiend overwicht en misleiding toelichting. Het bestanddeel bewegen vereist dat het slachtoffer zich heeft laten overhalen ontuchtige handelingen te plegen of van de dader te dulden. Er moet aldus sprake zijn van een causaal verband: de middelen hebben de ander tot het plegen of dulden van ontuchtige handelingen overgehaald. Wanneer de minderjarige uit zichzelf ontuchtige handelingen pleegt, is van bewegen geen sprake. Overhalen roept de vraag op of er sprake moet zijn van een psychische omslag. In art. $326 \mathrm{Sr}$, dat oplichting strafbaar stelt, wordt bewegen vrij objectief uitgelegd en omschreven als veroorzaken, waarbij enig 'psychisch omturnen' niet hoeft te worden vastgesteld. Ook ten aanzien van art. $248 \mathrm{~d}$ Sr wordt een objectieve uitleg voorgestaan, zij het dat daarbij meer rekening wordt gehouden met de omstandigheid dat sprake is van een minderjarige. Van een minderjarige wordt aangenomen dat deze kwetsbaar is en dus snel wordt overgehaald. Voor het omturnen van minderjarigen is met andere woorden niet veel nodig. Daarmee zou rekening moeten worden gehouden. ${ }^{135}$ Hoe jonger het kind, hoe groter die kwetsbaarheid, hoe sneller van bewegen kan

134 Rb. Rotterdam 5 april 2016, ECLI:NL:RBROT:2016:2538; Rb. Limburg 4 februari 2015, ECLI:NL: RBLIM:20I5:889.

I35 NLR aant. 2 bij art. 326; NLR aant. 3 bij art. 248d. Zie over het belang rekening te houden met de kwetsbaarheid van het slachtoffer bij de uitleg van bewegen ook Sackers in: Handboek Strafzaken, aant. IOI.7.3. 
worden gesproken. Een psychische omslag bij het (minderjarige) slachtoffer vormt al met al geen vereiste, maar draagt wel bij aan het bewijs van bewegen.

Misbruik van uit feitelijke verhoudingen voortvloeiend overwicht houdt verband met de positie van de dader ten opzichte van het slachtoffer. De dader moet overwicht hebben over het slachtoffer, wat betekent dat het slachtoffer zich in een ondergeschikte positie bevindt ten opzichte van de dader. Dat overwicht moet uit feitelijke verhoudingen voortvloeien; enkel juridisch overwicht is niet voldoende, maar kan wel een bijdrage leveren aan het bewijs ervan. Onder andere leeftijdsverschil en verschil in (maatschappelijke) positie worden in de rechtspraak als uit feitelijke verhoudingen voortvloeiend overwicht beschouwd. ${ }^{1{ }^{6} 6}$ Onder verschil in positie zou verschil in informatiepositie kunnen worden verstaan. Iemand kan over meer informatie beschikken dan een ander en daarmee een positie innemen die beter is dan die van de ander die deze informatie ontbeert, of weliswaar over die informatie beschikt maar liever niet heeft dat deze openbaar wordt gemaakt. Onder informatie zal in de regel schriftelijke informatie worden verstaan, maar het is denkbaar dat ook beeldmateriaal informatie vormt. In dat geval kan het bezit van naakt- of andere seksueel getinte foto's of films van een ander als informatie worden beschouwd die de bezitter een betere positie geeft ten opzichte van de ander en waarbij zou kunnen worden gesproken van overwicht, die voortvloeit uit een bepaalde verhouding tussen twee personen. Niet elk overwicht is strafrechtelijk relevant. Er moet misbruik van worden gemaakt. Dat wil zeggen dat op een andere wijze van het overwicht gebruik wordt gemaakt (of daarmee een situatie in het leven wordt geroepen) dan hetgeen met betrekking tot overwicht in de regel maatschappelijk betamelijk wordt geacht. Het gaat erom dat de keuzevrijheid van het slachtoffer door het uit feitelijke verhoudingen voortvloeiende overwicht tegen diens wil is verminderd. ${ }^{137}$

Misleiding betekent het 'door woord of gedrag voorspiegelen van een onware stand van zaken, waardoor de ander over de streep wordt getrokken'. ${ }^{13^{8}}$ Misleiding kan zich bijvoorbeeld voordoen wanneer iemand zich tijdens een chatgesprek voordoet als een leeftijdgenoot en tijdens dat gesprek (of meerdere gesprekken) de ander (telkens) overhaalt tot het plegen van ontuchtige handelingen met zichzelf. ${ }^{139}$ Uit feitenrechtspraak komt ook naar voren dat wat als misleiding begon kan uitmonden in seksuele afpersing. ${ }^{140}$ Een minderjarige kan door een ander worden

I36 T\&C Sr, aant. 6a bij art. 248a.

I37 T.a.v. art. 250 (oud) Sr, zie Kamerstukken II I988/89, 2I 207, nr. 3, p. 3 e.v. Zie ook A-G Vellinga vóór HR 8 september 2009, ECLI:NL:HR:2009:BJ3458. De enkele omstandigheid dat er sprake is van overwicht (zoals een groot leeftijdsverschil), levert dus niet zonder meer misbruik op. Opvallend is hier de vermenging van verschillende rechtsbelangen: de seksuele vrijheid en de bescherming van minderjarigen. Het is denkbaar dat Vellinga in zijn conclusie vooral adolescenten op het oog had. Bij kinderen die nog niet de fase van adolescentie hebben bereikt zal de keuzevrijheid een minder prominente rol spelen, maar de bescherming vooropstaan (vgl. art. 34 van het Internationaal verdrag inzake de rechten van het kind).

I3 8 NLR aant. 3 bij art. 248a; T\&C Sr aant. 6b bij art. 248 a Sr.

I39 Bijv. Rb. Rotterdam 4 juni 20I5, ECLI:NL:RBROT:20I5:3947; Rb. Alkmaar I4 februari 20I2, ECLI:NL:RBALK:20I2:BV5545; Rb. Haarlem 29 november 20II, ECLI:NL:RBHAA:20II:BVoo20. Vgl. Rb. Maastricht I4 april 20I0, ECLI:NL:RBMAA:20I0:BMIII7.

I40 Rb. Rotterdam 4 juni 20I5, ECLI:NL:RBROT:20I5:3947; Rb. Midden-Nederland I8 maart 20I5, ECLI:NL:RBMNE:2015:5617; Rb. Amsterdam I2 februari 2015, ECLI:NL:RBAMS:2015:673; Hof 's-Hertogenbosch 2I december 20I2, NJFS 20I3/5I; Rb. Breda I7 juli 20I2, ECLI:NL:RBBRE:20I2: BXI668. 
bewogen om zich voor de webcam te ontkleden. Deze sessies kunnen steeds indringender worden, waarbij het bewegen langzamerhand omslaat in dwang door bedreiging. Het omslagpunt zal niet altijd eenvoudig zijn vast te stellen, waardoor - in het belang van de bescherming van minderjarigen - het gewenst lijkt de lijn tussen verleiding en dwang (ook wanneer die is opgenomen in Titel XIV (zoals art. $246 \mathrm{Sr})$ ) niet al te strak te trekken.

Het voorgaande geeft aanleiding te denken dat verschillende vormen van seksuele afpersing strafbaar zijn, terwijl ook de voorfase niet zonder meer buiten het bereik van de strafwet valt. De strafbaarheid van dergelijke gedragingen ligt wel deels buiten Titel XIV van het Tweede Boek. Zij wordt daarmee niet zozeer gerechtvaardigd door de rechtsbelangen die Titel XIV beoogt te beschermen, 'de lichamelijke en seksuele integriteit en het seksuele zelfbeschikkingsrecht' en de bescherming van (de seksuele ontwikkeling van) minderjarigen. De strafbaarstellingen van afpersing, afdreiging en dwang beogen alle de persoonlijke vrijheid te beschermen. Het verschil tussen de persoonlijke vrijheid en de lichamelijke en seksuele integriteit en het seksuele zelfbeschikkingsrecht lijkt niet bijzonder groot. Persoonlijke vrijheid zou kunnen worden beschouwd als het overkoepelende rechtsbelang, terwijl de lichamelijke en seksuele integriteit en het seksuele zelfbeschikkingsrecht als een nadere invulling daarvan zouden kunnen worden beschouwd. Het verwijt dat in de bestaande strafbepalingen tot uitdrukking wordt gebracht, de onrechtmatige schending van de lichamelijke en seksuele integriteit, lijkt het seksuele zelfbeschikkingsrecht met andere woorden te verdisconteren. Dat roept de vraag op of aparte strafbaarstelling van seksuele afpersing een meerwaarde heeft, temeer daar is gebleken dat seksuele afpersing een veelheid aan gedragingen betreft waardoor men zich kan afvragen of deze gedragingen in één nog enigszins begrijpelijke strafbaarstelling kunnen worden ondergebracht.

\section{$4 \quad$ Wraakporno}

\section{I Wraakporno en in het geding zijnde rechtsbelangen}

Wraakporno kan worden omschreven als het online publiekelijk delen van 'sexually explicit images (...) without the consent of the pictured individual'. ${ }^{\text {III }}$ Soms wordt ook het dreigen deze afbeeldingen openbaar te maken beschouwd als een vorm van wraakporno. ${ }^{142}$ Het openbaar maken of het dreigen openbaar te maken van dergelijke afbeeldingen heeft tot doel wraak te nemen op de afgebeelde persoon of de persoon wiens naam bij de afbeelding is vermeld (hetgeen niet de persoon hoeft te zijn die is afgebeeld). Wraakporno wordt als een ernstig feit beschouwd, waarvan vooral vrouwen slachtoffer zijn. Ter onderbouwing hiervan wordt gewezen op de angst die wraakporno bij slachtoffers teweegbrengt. Niet alleen de angst nadat de afbeeldingen op het internet openbaar zijn gemaakt, maar ook de angst van de dreiging dat zij openbaar worden gemaakt. Die angst zorgt ervoor dat daders controle op slachtoffers kunnen (blijven) uitoefenen. Openbaar

I4I Levendowski 20I4, p. 425. Zie ook Franklin 2014, p. I306; Scheller 2015, p. 558.

I42 Citron en Franks 20I4, p. 35I. 
gemaakte afbeeldingen kunnen tot problemen leiden op de arbeidsmarkt en in het leven van alledag. De afbeeldingen kunnen openbaar zijn gemaakt op zogeheten 'slut-shaming sites' waar de geplaatste afbeeldingen gepaard gaan met vernederende beschrijvingen van het slachtoffer. Wanneer de openbaar gemaakte afbeeldingen gepaard gaan met opmerkingen dat het slachtoffer zich aanbiedt voor seks en daarbij naam, telefoonnummer en/of e-mailadres worden vermeld, kan het slachtoffer niet alleen door de persoon die de afbeelding heeft geplaatst, maar ook door derden worden lastiggevallen, zo vaak zelfs dat gesproken wordt van (cyber-) stalking. Slachtoffers van wraakporno rapporteren ook verlies van persoonlijke waardigheid en respect van anderen (familie, vrienden, werkgever en dergelijke). ${ }^{143}$

Alles bij elkaar genomen zijn bij wraakporno verschillende rechtsbelangen in het geding. In de eerste plaats wordt wraakporno beschouwd als een delict tegen de seksuele vrijheid. Wraakporno brengt schade toe aan de seksuele integriteit van het slachtoffer als gevolg van dwang of bedreiging. Hiermee samenhangend wordt, in de tweede plaats, wraakporno omschreven als een delict tegen de persoonlijke vrijheid, of privacy. De van het slachtoffer gemaakte foto's of films zijn vaak in de beslotenheid van een woning of (hotel)kamer genomen met toestemming van het slachtoffer, dat in de veronderstelling verkeerde dat zij niet zouden worden geopenbaard. De openbaring ervan, zonder toestemming van het slachtoffer, raakt aan de privacy waarvan het slachtoffer dacht dat die zou worden gerespecteerd. ${ }^{\mathrm{I} 44}$ In de derde plaats tast wraakporno de eer en goede naam van het slachtoffer aan. ${ }^{\mathrm{I} 5}$ Die aantasting wordt versterkt, doordat de afbeeldingen vaak niet volledig van het internet zijn te verwijderen. Uit de rechtspraktijk blijkt dat een provider van User Generated Content (bijvoorbeeld Facebook) niet snel bereid is (of in staat is) een verzoek tot verwijdering van wraakporno te honoreren. ${ }^{14^{6}}$ Uit de in het geding zijnde rechtsbelangen blijkt dat het aansprakelijk stellen voor wraakporno op verschillende manieren kan worden gerealiseerd.

\subsection{Huidige strafbaarstellingen tegen wraakporno}

Het plaatsen van wraakporno op internet kan door meerderjarigen en minderjarigen geschieden. Ook het slachtoffer kan meerderjarig of minderjarig zijn. In het laatste geval geldt dat het verspreiden van afbeeldingen van seksuele gedragingen strafbaar is op grond van art. 24ob Sr. Het plaatsen van naaktfoto's van minderjarigen op een voor iedereen toegankelijke website kan, ervan uitgaande dat deze foto's aanstotelijk voor de eerbaarheid zijn, ook strafbaar zijn op grond van art. 239 en $240 \mathrm{Sr}$. Tevens is het denkbaar dat deze gedragingen schadelijk zijn te achten. Dan komt art. $240 \mathrm{a}$ Sr in beeld.

I43 Citron en Franks 20I4, p. 350-354; Franklin 20I4, p. I309-I3I0; Scheller 20I5, p. 559-565.

I44 Citron en Franks 20I4, p. 36r-365; A.N. Kitchen, 'The Need to Criminalize Revenge Porn: How a Law Protecting Victims Can Avoid Running Afoul of the First Amendment', Chigago-Kent Law Review 2015, p. 247-250, 254-255; C. Martinez, 'An Argument for States to Outlaw "Revenge Porn" and for Congress to Amend 47 U.S.C. \$ 230: How Our Current Laws Do Little to Protect Victims', Journal of Technology, Law \& Policy 20I4, p. 238-239.

I45 Van der Hof 2016, p. 56; Kitchen 2015, p. 254.

I46 Rb. Amsterdam 25 juni 20I5, Computerrecht 20I5/I63, m.nt. Lodder. Zie ook Scheller 20I5, p. 559565. 
Het ligt minder voor de hand dat naaktfoto's of naaktfilms van meerderjarigen die op internet zijn geplaatst (zoals een website voor en met wraakporno), vallen onder art. 239 en 240 Sr. Dergelijke afbeeldingen zullen, hoe vervelend zij voor het slachtoffer ook zijn, minder snel strijdig zijn met de hier te lande heersende zeden. Naakt behoort, voor zover het meerderjarige personen betreft en behoudens uitzonderingen, tot het dagelijks leven. Andere strafbaarstellingen binnen Titel XIV lijken geen mogelijkheden te bieden het plaatsen van wraakporno op een website te bestraffen. Buiten deze titel komen wel verschillende strafbepalingen in aanmerking. Zo kan wraakporno een vorm van seksuele afpersing of afdreiging zijn. ${ }^{\mathrm{I} 7}$ Wraakporno hoeft echter niet met bijvoorbeeld bedreiging met geweld gepaard te gaan. Uit onderzoek blijkt bijvoorbeeld dat slachtoffers lastig worden gevallen nadat één of meer afbeeldingen met hun gegevens (naam, telefoonnummer, woon- en/of e-mailadres) op internet zijn geplaatst. Dit kan, zoals hiervoor al werd opgemerkt, onder omstandigheden belaging opleveren.

Slachtoffers voelen zich door wraakporno in hun eer en goede naam aangetast. Voor deze gevallen komen de in Titel XVI van het Tweede Boek (Belediging) opgenomen strafbaarstellingen in beeld. Zo kan smaad (het opzettelijk aanranden van iemands eer of goede naam door tenlastelegging van een bepaald feit) geschieden door middel van afbeeldingen (op het internet) (art. 26I lid 2 Sr). Dan spreken we van smaadschrift. Uit lagere rechtspraak blijkt dat een op het internet geplaatste foto of film waarop iemand naakt te zien is, soms wel, soms geen belediging oplevert. ${ }^{148}$ Het Hof Leeuwarden hechtte bijvoorbeeld veel belang aan de 'context' waarin het filmpje was geplaatst en/of het 'karakter' van de beelden, in het bijzonder de wijze waarop de persoon in het filmpje was te zien en oordeelde dat in casu geen sprake was van belediging, omdat het openbaar maken van naaktbeelden op zichzelf niet strafbaar is, terwijl de context waarin het filmpje was geplaatst niet duidelijk was geworden. ${ }^{149}$

De advocaat-generaal Spronken concludeerde in een zaak waarin ter discussie stond de betekenis van het in art. 26I lid I Sr voorkomende bestanddeel 'door te-

I47 Hof Amsterdam I7 september 20I5, ECLI:NL:GHAMS:20I5:4348; Rb. Den Haag 3 april 20I3, ECLI:NL:RBDHA:2013:3610; Rb. Arnhem 2 november 2010, ECLI:NL:RBARN:2010:BO2746.

I48 Rb. Limburg 2 februari 20I6, ECLI:NL:RBLIML20I6:843.

I49 Hof Leeuwarden 4 mei 20I0, ECLI:NL:GHLEE:20I0:BM3I69. De verdachte werd wel veroordeeld wegens overtreding van de Auteurswet. De door het hof gebruikte termen lijken te verwijzen naar art. Io EVRM. Helemaal vreemd is dat niet. In Amerikaanse literatuur wordt erop gewezen dat wraakporno vaak niet strafbaar zou zijn omdat de handelingen zouden worden beschermd door het eerste Amendement op de Amerikaanse grondwet (het 'free speech'-amendement). Zie Kitchen 2015; Scheller 2015. Het EHRM acht de vrijheid van meningsuiting van groot belang in een democratische samenleving. Dat recht strekt zich ook uit tot de publicatie van foto's. Tegelijkertijd erkent het Hof dat juist met betrekking tot afbeeldingen een balans moet worden gevonden met het recht op persoonlijke levenssfeer. Dat omvat ook het recht om controle uit te oefenen op afbeeldingen ('images') die van een persoon zijn gemaakt, omdat foto's zeer persoonlijke en intieme informatie bevatten van de persoon die daarop is afgebeeld. Voor het publiceren van foto's moet een 'pressing social need' bestaan, ter beoordeling daarvan moet worden gekeken naar de eventuele bijdrage aan een debat van algemeen belang, de bekendheid van de afgebeelde persoon, eerdere handelingen van die persoon, de methode van verkrijging van de foto's alsmede de omstandigheden waaronder de foto's zijn genomen en de inhoud, vorm en gevolgen van publicatie van de foto's (zie samengevat in o.a. EHRM 4 december 20I2, nr. 6490/o7, Rothe/ Oostenrijk, par. 5I). Het publiceren van naaktfoto's is dus niet in alle gevallen onaanvaardbaar. Het publiceren van naaktfoto's van een onbekend persoon met als motief het nemen van wraak lijkt, gelet op deze criteria, buiten het bereik van art. Io lid I EVRM te vallen. Wanneer wraakporno strafbaar is gesteld, levert dat in het kader van art. Io EVRM dus geen problemen op. 
lastlegging van een bepaald feit' dat het daarbij ook kan gaan 'om een duidelijk te onderkennen concrete historische gedraging waarbij de betrokkenheid van het slachtoffer bij dat feit tot uitdrukking komt'. Die concrete historische gedraging moet 'naar huidige morele maatstaven geschikt (...) [zijn] om de integriteit aan te tasten van de persoon - of degene die wordt aangemerkt als de persoon - die in het filmpje te zien was'. In casu ging het om een op internet geplaatst filmpje waarin een minderjarig meisje seksuele handelingen met zichzelf verrichtte, waarbij telkens de naam van een ander minderjarig meisje werd vermeld. Dat meisje beklaagde zich over het filmpje. Volgens Spronken was een dergelijk filmpje 'ook naar huidige morele maatstaven' 'evident geschikt' om de integriteit van het slachtoffer aan te tasten..$^{150}$ Daarbij werd meegewogen dat het slachtoffer ten tijde van de gedragingen minderjarig was. De Hoge Raad oordeelde dat met de in beeld gebrachte suggestie dat het slachtoffer de vrouw was die de seksuele handelingen in het filmpje verrichtte, de eer en goede naam van het slachtoffer was aangerand. ${ }^{15}$ Anders dan de advocaat-generaal wees de Hoge Raad niet expliciet op de leeftijd van het slachtoffer. Mogelijk doet het in een geval als het onderhavige niet terzake hoe oud het slachtoffer was wier naam in een filmpje wordt genoemd en die in verband wordt gebracht met de daarin vertoonde seksuele handelingen, mits, zoals we in paragraaf 5.I zullen zien, er wel een verband bestaat tussen de vertoonde seksuele handelingen en het slachtoffer. Op deze manier is niet elk gebruik van (de naam of afbeeldingen van) een persoon in een filmpje waarop seksuele handelingen zijn te zien strafbaar. Met deze beperking bieden de beledigingsbepalingen enige mogelijkheden tegen het gebruik of plaatsen van afbeeldingen, die uit wraak zijn geplaatst of gebruikt, strafrechtelijk op te treden.

\subsection{Wraakporno en het Wetsvoorstel Computercriminaliteit III}

De minister van Veiligheid en Justitie heeft onlangs aangekondigd strafrechtelijke maatregelen te willen nemen tegen wraakporno. Een maatregel om wraakporno te bestrijden is het strafbaar stellen van het wederrechtelijk kopiëren van vertrouwelijke gegevens, waaronder afbeeldingen van seksuele handelingen. ${ }^{152}$ Dit geschiedt in het nieuwe art. $138 \mathrm{c} \mathrm{Sr}$ dat in het huidige voorstel luidt:

'Met gevangenisstraf van ten hoogste een jaar of geldboete van de vierde categorie wordt gestraft degene die opzettelijk en wederrechtelijk niet-openbare gegevens die zijn opgeslagen door middel van een geautomatiseerd werk, voor zichzelf of voor een ander overneemt.'

Art. I38c Sr wordt opgenomen in Titel V van het Tweede Boek. Daarin staan de misdrijven tegen de openbare orde. Dat maakt duidelijk dat de strafbaarstelling niet alleen met het oog op de bestrijding van wraakporno is voorgesteld. De strafbaarstelling wordt ingevoegd, 'vooral met het oog op bescherming van de persoon-

I50 Conclusie A-G Spronken, ECLI:NL:PHR:20I3:I54I, punt I2 en I5.

I5I HR 3 december 20I3, NJ 20I4/46.

I52 Kamerstukken II 20I4/I5, Aanhangsel van de Handelingen, nr. 856; Kamerstukken II 20I4/I5, Aanhangsel van de Handelingen, nr. 2837. 
lijke levenssfeer van degene wiens gegevens het betreft'. ${ }^{53}$ Strafbaarstelling zou ook gewenst zijn omdat met de overgenomen gegevens andere misdrijven kunnen worden gepleegd, waardoor schade aan anderen kan worden toegebracht. Het laatste argument maakt duidelijk waarom de voorgestelde strafbaarstelling meer beschermt dan de persoonlijke levenssfeer; het overnemen van niet-openbare gegevens tast niet alleen de privacy van individuen aan. Omdat met het overnemen andere strafbare feiten kunnen worden begaan, is de openbare orde in het geding. Wanneer een ander maatschappelijk belang echter zwaarder weegt en het overnemen binnen de grenzen van proportionaliteit en subsidiariteit blijft, is er volgens de memorie van toelichting geen sprake van wederrechtelijk overnemen. ${ }^{154}$ De openbare orde is in dat geval niet verstoord. Daarmee is echter niet gezegd dat de privacy (of de eer of goede naam) van het slachtoffer evenmin is verstoord. Tegelijkertijd kan de vrijheid van meningsuiting onder omstandigheden openbaring van gegevens vorderen. ${ }^{155}$ Hier kunnen de verschillende rechtsbelangen die art. I38c Sr beoogt te beschermen met elkaar in conflict komen, hetgeen de rechter voor lastige interpretatievragen kan stellen. Wanneer de nadruk wordt gelegd op de openbare orde als het beschermde rechtsbelang, zou dat tot een interpretatie van art. $138 \mathrm{c}$ Sr kunnen leiden die slachtoffers van wraakporno minder gunstig is gezind. Een en ander hangt mede af van de interpretatie van het rechtsbelang openbare orde, iets waarover weinig overeenstemming bestaat. Nadere toelichting van de wetgever over openbare orde en beter inzicht in de verhouding tussen de betrokken rechtsbelangen lijkt al met al gewenst.

Verschillende onderdelen van de voorgestelde bepaling verdienen toelichting. Allereerst wordt, in lijn met andere cybercrimedelicten in het Wetboek van Strafrecht, gesproken van gegevens (art. 8oquinquies Sr). Hieronder vallen ook bestanden met foto's of films. Niet-openbaar zijn gegevens wanneer zij niet voor iedereen toegankelijk waren op het moment dat zij werden overgenomen. Met het bestanddeel overneemt wordt duidelijk gemaakt dat de gegevens niet buiten de beschikkingsmacht van de rechthebbende worden gebracht. ${ }^{15^{6}} \mathrm{Het}$ bestanddeel wederrechtelijk wijst, we zagen het al, op begrenzing van de door art. I38c Sr te beschermen rechtsgoederen. Uit de tekst van het voorstel moet worden afgeleid dat wederrechtelijkheid moet bestaan ten tijde van het overnemen. Wanneer die toestemming na het overnemen wordt ingetrokken, betekent dat niet dat het overnemen strafbaar wordt. Achteraf ingetrokken toestemming neemt de strafbaarheid niet weg. Het ligt niet zonder meer voor de hand dat niet expliciet gegeven toestemming voldoende is voor wederrechtelijkheid. Dat ligt eerder voor de hand wanneer het centrale rechtsbelang de privacy zou zijn. Nu het rechtsbelang niet zonder meer duidelijk is, bestaat over de betekenis van het bestanddeel wederrechtelijkheid onzekerheid.

Juist bij de problematiek van pas achteraf ingetrokken toestemming wringt bij wraakporno de schoen. Wat als een persoon (bijvoorbeeld een ex-partner) reeds in het bezit is van seksueel getinte foto's of films, omdat hij of zij die gegevens van

I53 Kamerstukken II 2015/16, 34 372, nr. 3, p. 62, 65.

I54 Kamerstukken II 20I5/I6, 34 372, nr. 3, p. 66.

I55 Vgl. EHRM 4 december 20I2, nr. 6490/07 (Rothe/Oostenrijk).

I56 Kamerstukken II 20I5/I6, 34 372, nr. 3, p. 64. 
het slachtoffer (zijn toenmalige partner) heeft gekregen of met diens toestemming naar zichzelf heeft gezonden, en eerst na beëindiging van de relatie op internet plaatst? ${ }^{57}$ Als vaststaat dat de gegevens zijn overgenomen met toestemming van de ander, en die trekt later zijn of haar toestemming in, dan maakt dat het overnemen niet met terugwerkende kracht wederrechtelijk. Zo bezien lijkt het voorgestelde art. $138 \mathrm{c}$ Sr niet zonder meer tegen alle vormen van wraakporno te beschermen en moet worden teruggevallen op de in de vorige subparagraaf genoemde strafbaarstellingen.

\section{$5 \quad$ Sexting en sexchatting}

\section{I Sexting: het verzenden van foto's of films}

Sexting werd in paragraaf I.3 omschreven als 'het sturen van seksueel getinte berichten of foto's of films, meestal via de smartphone'. ${ }^{158}$ Het sturen van foto's of films van (een) seksuele gedraging(en) door (een) minderjarige(n) kan onder omstandigheden strafbaar zijn als kinderpornografie, zoals de minister van Veiligheid en Justitie aangaf. Het versturen van seksueel getinte foto's of films van meerderjarigen aan minderjarigen kan eveneens strafbaar zijn (art. 240a Sr), terwijl ook art. $240 \mathrm{Sr}$ in het vizier zou kunnen komen.

We zagen dat het op internet plaatsen van afbeeldingen van seksuele handelingen de eer of goede naam van de persoon of personen die deze gedraging(en) verricht(en) kan aanranden. Afbeeldingen van personen zijn vanwege internet vaak goed beschikbaar en worden voor allerlei doeleinden gebruikt, ook door anderen dan de persoon die op de afbeelding staat. Op die manier kan zelfs een onschuldige foto worden gebruikt in heel wat minder onschuldige films of collages van foto's die aan anderen worden verspreid. Dat overkwam een vrouw van wie de profielfoto van haar Facebook-pagina was toegevoegd aan een filmpje waarop te zien was dat twee mensen geslachtsgemeenschap hadden, terwijl tussen de getoonde naaktscènes door onder andere de profielfoto van aangeefster was te zien. De maker had het filmpje via WhatsApp aan een vriend verzonden, waarschijnlijk met het verzoek het filmpje niet verder te verspreiden. Aangeefster heeft het filmpje zelf niet ontvangen, maar was daarop door een ander attent gemaakt. ${ }^{159}$ De maker van het filmpje werd door het hof veroordeeld voor eenvoudige belediging van de aangeefster (art. 266 lid I Sr). Het hof oordeelde dat hij het opzet op belediging had, mede omdat 'dit soort filmpjes nadat ze eenmaal via de sociale media zijn verstuurd, een eigen leven plegen te gaan leiden en dat deze daardoor op enig moment ter kennis kunnen komen van het slachtoffer'. Daarmee had hij bewust de aanmerkelijke kans aanvaard dat het filmpje aangeefster zou bereiken en zij door het filmpje in haar eer en goede naam zou worden aangerand.

I57 Zou hij na het beëindigen van de relatie zich zonder toestemming toegang verschaffen tot de gegevens, dan kan sprake zijn van computervredebreuk (art. I38ab Sr).

I58 Kamerstukken II 20I5/I6, 29 279, nr. 300, p. 2; Aanhangsel Handelingen II 2015/I6, nr. I678.

I59 De seksueel getinte foto's of films kunnen bij sexting van de betrokkenen zelf zijn, maar ook, zo blijkt uit deze casus, van derden, die daarvan soms niet en soms wel op de hoogte raken. 
In cassatie werd bestreden dat het tonen van de profielfoto van de vrouw de strekking had haar in een slecht daglicht te plaatsen en aan te randen in haar eer en goede naam. Tevens werd bestreden dat de verdachte het opzet op belediging had. Zowel de advocaat-generaal als de Hoge Raad kwam tot het oordeel dat het arrest van het hof niet in stand kon blijven. De advocaat-generaal, Bleichrodt, stelde dat de context waarin de afbeelding is geplaatst bepalend is voor het antwoord op de vraag of er sprake is van belediging van de aangeefster. ${ }^{160} \mathrm{Hij}$ kwam tot de conclusie dat, hoewel het begrijpelijk is dat de vrouw niet met het filmpje wenste te worden geassocieerd, de enkele omstandigheid dat een afbeelding van haar in het filmpje werd getoond niet beledigend is in de zin van art. 266 lid I Sr. Ook van opzet was volgens Bleichrodt geen sprake. De enkele toezending van het filmpje van verdachte aan een vriend (tegen wie hij zou hebben gezegd het niet verder te verspreiden) betekent niet dat hij bewust de aanmerkelijke kans aanvaardde dat het filmpje ter kennis zou komen van aangeefster. ${ }^{\mathrm{I} \text { I }}$

Volgens de Hoge Raad had het hof

'in het bijzonder niets vastgesteld omtrent het verband dat in het filmpje wordt gelegd of gesuggereerd tussen de getoonde foto van de aangeefster en het tonen van de door een andere vrouw verrichte seksuele gedragingen. Aan de enkele omstandigheid dat de foto van de aangeefster in dit filmpje is opgenomen kan nog niet worden ontleend dat het tonen van die afbeelding de strekking heeft de aangeefster in een ongunstig daglicht te plaatsen en haar aan te randen in haar eer en goede naam. ${ }^{{ }^{1} 6_{2}}$

De Hoge Raad sluit dus niet uit dat een afbeelding die op zichzelf een beledigend karakter ontbeert, belediging kan opleveren, ofwel omdat door de wijze van presenteren een verband wordt gelegd met seksuele gedragingen van een andere persoon dan de persoon op de afbeelding, ofwel omdat dit verband wordt gesuggereerd. Het wekken van suggestie laat ruimte open voor een oordeel waarin gelet op de plaats waarin de foto in een filmpje wordt gebruikt en de wijze van gebruik van een foto van een onwetende ander toch beledigend is. Op die manier is belediging door gebruik van een (profiel)foto niet ondenkbaar. Wie bepaalt dat de suggestie wordt gewekt: is dat de aangever die meent dat hij in zijn eer of goede naam is aangetast, of is dat de rechter met in achtneming van alle relevante omstandigheden van het geval? Het eerste maakt het mogelijk dat ook het voor de gemiddelde buitenstaander onschuldige gebruik van afbeeldingen in een seksueel getinte film of fotocollage, belediging oplevert. Of er dan ook werkelijk sprake is van strafbare belediging, zal in belangrijke mate afhangen van het opzet van de verdachte. In het tweede geval lijkt de ruimte om tot strafbare belediging te komen wat minder groot en in ieder geval minder afhankelijk van de subjectieve beleving van het slachtoffer en de intentie van de dader. De uitspraak van de Hoge Raad wekt de indruk dat hij voor de tweede interpretatie kiest.

I6o Vgl. HR 22 december 2009, NJ 2010/67I, m.nt. Buruma.

I6I Conclusie A-G Bleichrodt, ECLI:NL:PHR:2015:I937.

I62 HR ro november 20I5, ECLI:NL:HR:20I5:3247. 


\subsection{Sexting en sexchatting: het voeren van seksuele gesprekken}

Sexting kan ook bestaan in het sturen van berichten over seks of iemand (op internet) aanspreken over seks. Van sexting is ook sprake wanneer het bericht onbeantwoord blijft. Wordt een bericht wel beantwoord dan is sprake van sexchatting. Sexchatting vindt plaats tussen minderjarigen, tussen een meerder- en minderjarige en tussen meerderjarigen. Ook meerderjarigen die zijn getrouwd of een vaste relatie hebben doen aan sexchatting. ${ }^{163}$ Dit wordt online, cyber- of internetoverspel genoemd. ${ }^{164}$ Nationaal en internationaal wordt vooral de onwenselijkheid van sexting en sexchatting met minderjarigen benadrukt. Door de Europese Commissie werd in 2007 aangegeven dat werd onderzocht of behoefte bestond om seksuele handelingen tegen minderjarigen die 'via netwerken voor elektronische en informatiesystemen worden gepleegd' strafbaar te stellen. ${ }^{165}$

In de preambule van Richtlijn 2011/93/EU staat dat seksueel misbruik en uitbuiting van kinderen niet alleen toenemen maar ook worden verspreid door het gebruik van onder meer internet (overweging 3). Strafbaarstelling van gedragingen op internet wordt niet beoogd met betrekking tot 'persoonlijke rechtstreekse communicatie met wederzijds goedvinden tussen gelijken of tussen kinderen die de leeftijd van seksuele meerderjarigheid hebben bereikt en hun partners' (overweging 8). Kennelijk zijn slechts bepaalde gedragingen zo problematisch dat zij onder het bereik van de strafwet dienen te vallen. Daarvan uitgesloten kunnen zijn persoonlijke rechtstreekse gesprekken zonder wederzijds goedvinden tussen gelijken, tussen minderjarigen die nog niet seksueel meerderjarig zijn en niet communiceren met hun partner en tussen minder- en meerderjarigen (die al dan niet hun partner zijn) (overweging 20), iets wat we in het kader van kinderpornografie reeds zagen in par. 2.5.

In het bijzonder wijst de Richtlijn op de strafbaarstelling van grooming (zie par. 6). Grooming is een bijzondere variant van sexchatting, omdat met de sexchat iets wordt beoogd, namelijk een ontmoeting met de minderjarige waarbij deze bijvoorbeeld seksueel zal worden misbruikt. Voor strafbaarheid van grooming is niet nodig dat het chatten tegen de wil van het slachtoffer plaatsvindt. Uit de preambule van de Richtlijn blijkt dat grooming als een voorbeeld wordt beschouwd van ongewenst benaderen van minderjarigen voor seksuele doeleinden (overweging I9). ${ }^{166}$ Niet uitgesloten is dat ook andere vormen van seksuele gesprekken met minderjarigen strafbaar kunnen zijn. In de Richtlijn zijn echter geen bepalingen opgenomen op basis waarvan sexting en sexchatting zonder meer strafbaar moeten worden gesteld. Zij moeten slechts strafbaar worden gesteld wanneer dat

I63 B.L.A. Mileham, 'Online Infidelity in Internet Chat Rooms: An Ethnographic Exploration', Computers in Human Behavior 2007, p. II-3I; M.T. Whitty, 'Liberating or Debilitating? An Examination of Romantic Relationships, Sexual Relationships and Friendships on the Net', Computers in Human Behavior 2008, p. I843. Onderzoek wijst uit dat sexchatting en sexting onder volwassenen meer dan geregeld voorkomen. Zie bijv. D. Gordon-Messer e.a., 'Sexting among Young Adults', Journal of Adolescent Health 2013, p. 30I-306.

I64 K.M. Hertlein en F.P. Piercy, 'Internet Infidelity: A Critical Review of the Literature', The Family Journal 2006, p. 366.

I65 Verslag van de commissie op basis van artikel I2 van het Kaderbesluit van de Raad van 22 december 2003 ter bestrijding van seksuele uitbuiting van kinderen en kinderpornografie van I6 november 2007, $\operatorname{COM(2007)716~definitief,~p.~} 9$.

I66 Vgl. Kamerstukken II 2008/o9, 3I 8Io, nr. 3, p. 2. 
met een minderjarige plaatsvindt en met een bepaald doel, zoals in het geval van grooming.

Zijn sexting en sexchatting, voor zover het gaat om seksuele gesprekken, op basis van bestaande strafbaarstellingen strafbaar? Het voorgaande wekt de indruk van niet. Toch lijken sexting en sexchatting onder verschillende strafbepalingen te kunnen worden geschaard, zowel binnen als buiten de zedentitel. ${ }^{167}$ Als eerste kan worden gedacht aan art. $239 \mathrm{Sr}$ (par. 5.3). Ook art. 285 br (belaging) (par. 5.4) lijkt mogelijkheden te bieden sexting en sexchatting te bestraffen. In de rechtspraak worden sexting en sexchatting bestraft als bedreiging of als poging tot ontuchtige handelingen (par. 5.5). Met een analyse van de rechtspraak over poging tot verleiding wordt deze paragraaf afgesloten (par. 5.6).

\subsection{Schennis van de eerbaarheid (art. 239 Sr)}

Art. 239 Sr luidt:

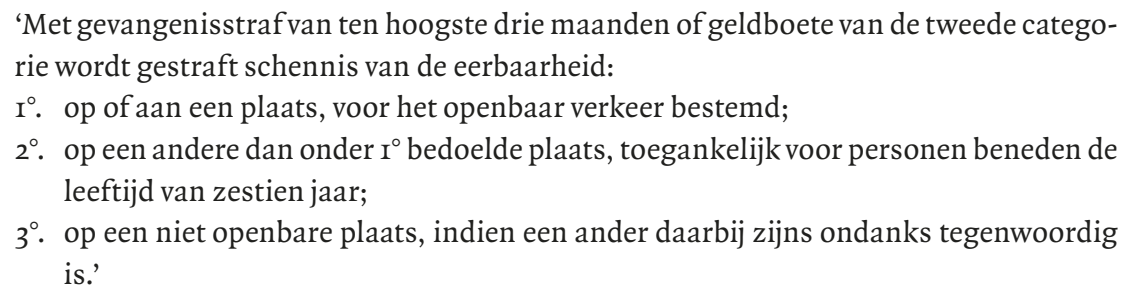

Art. 239 Sr heeft twee hoofddoelen: bescherming van de jeugd en bescherming tegen ongevraagde en ongewilde confrontatie. Met art. 239 Sr wordt getracht een balans te vinden tussen 'met name de vrijheid van meningsuiting enerzijds, en van het belang van de bescherming van jeugdigen en van degenen die van bepaalde uitingen juist geen kennis willen nemen anderzijds'. Bij meerderjarigen gaat het dus om de afbakening van rechten tussen burgers, terwijl het bij de bescherming van minderjarigen gaat 'om de bescherming van de opgroeiende mens tegen misbruik van diens zwakkere positie'. ${ }^{168}$ Deze rechtsbelangen zagen we al bij de bespreking van het aan art. 239 verwante art. $240 \mathrm{Sr}$ (par. 2.6).

Net als bij art. 240 Sr neemt eerbaarheid in art. 239 Sr een prominente plaats in. De betekenis van, in het geval van art. $239 \mathrm{Sr}$, schennis van de eerbaarheid is in par. 2.6 aan de orde geweest. Hierover kan nog het volgende worden opgemerkt. De eerbaarheid schennende gedraging moet voor derden waarneembaar zijn geweest. Hierbij gaat het om de confrontatie met het (geheel of gedeeltelijk naakte) menselijk lichaam of delen daarvan. ${ }^{169}$ Die waarneming kan volgens vaste rechtspraak ook met behulp van een technisch hulpmiddel geschieden, bijvoorbeeld een webcam. ${ }^{170}$ Onder welk onderdeel van art. 239 Sr moet dergelijk gedrag worden ge-

I67 Anders: Kamerstukken II 2008/o9, 3I 8Io, nr. 7, p. 4 .

I68 Kamerstukken II I979/80, I5 836, nrs. I-3, p. 6.

I69 HR I7 december 20I3, NJ 20I4/I49, m.nt. Keijzer.

I70 Rb. Midden-Nederland 5 maart 20I4, ECLI:NL:RBMNE:20I4:I007; Hof Den Haag I9 februari 20I4, ECLI:NL:GHDHA:20I4:863; Rb. Arnhem I5 april 20I0, ECLI:NL:RBARN:20I0:BMII67. Wanneer het slachtoffer voorkómt dat het met de aangekondigde seksuele gedraging van de 
plaatst? Het eerste onderdeel zou daarvoor in aanmerking kunnen komen, omdat het internet onder omstandigheden geldt als een openbare plaats. Met het woord 'aan' in art. 239 Sr is het mogelijk dat ook gedragingen die op een niet-openbare plaats plaatsvinden, zoals de (eigen) woning, maar wel op een openbare plaats zichtbaar zijn, strafbaar zijn op grond van het eerste onderdeel van art. 239 Sr. Het tonen van het naakte lichaam in de beslotenheid van de (eigen) woning aan een ander via een webcam wordt in de rechtspraak echter veelal onder het tweede of derde onderdeel van art. $239 \mathrm{Sr}$ gebracht. De plaatsen als bedoeld in het tweede onderdeel zijn 'weliswaar vrij toegankelijk' maar iemand gaat daar 'niet argeloos met het oog op het aldaar gebodene' naar binnen. ${ }^{17 \mathrm{I}}$ Het via een webcam aan een ander tonen van het (gedeeltelijk) naakte lichaam op een internetsite die met behulp van een wachtwoord toegankelijk is, lijkt (ook) onder het tweede onderdeel van art. 239 Sr te vallen. Ook in het geval een minderjarige zich vrijwillig toegang tot de website heeft verschaft en met het (gedeeltelijk) naakte lichaam van een ander wordt geconfronteerd, is die ander strafbaar. In het geval de confrontatie niet vrijwillig is, komt het derde onderdeel van art. $239 \mathrm{Sr}$ in beeld. Lindenberg en Van Dijk wijzen erop dat de Hoge Raad 'zijns ondanks' ook aanneemt wanneer sprake is van het ontbreken van besef, terwijl uit lagere rechtspraak blijkt dat daarover ook anders wordt gedacht. ${ }^{172}$ Met betrekking tot het onderdeel 'tegenwoordig is' blijkt uit de door Lindenberg en Van Dijk besproken feitenrechtspraak dat die er geen moeite mee heeft daaronder ook 'live stream' contact te verstaan. We zagen dat het niet zonder meer duidelijk is of dergelijk contact met minderjarigen ook overtreding van art. $240 \mathrm{a}$ (en 240b) Sr kan opleveren. Zou dat het geval zijn, dan kan dezelfde gedraging dus onder verschillende bestanddelen van uiteenlopende strafbaarstellingen met verschillende strafmaxima vallen. ${ }^{173}$ Dat hoeft niet problematisch te zijn, nu het derde onderdeel van art. 239 Sr niet alleen op minderjarigen ziet. Dat is bij art. 240a (en 240b) Sr wel het geval.

Kan er ook sprake zijn van schennis van de eerbaarheid wanneer de gedraging slechts bestaat in het uiten van seksueel getinte bewoordingen? De wetssystematiek sluit uit dat bewoordingen die schriftelijk ter kennis van de ander komen onder art. 239 Sr vallen. Hetzelfde geldt overigens voor art. $240 \mathrm{Sr} .{ }^{174}$ Wanneer de bewoordingen via een webcam worden geuit, verzet de wettekst noch de huidige wetssystematiek zich ertegen dit gedrag onder het bereik van art. 239 Sr te laten vallen. In een zaak waarin een man telefonisch een vrouw een oneerbaar voorstel deed, concludeerde advocaat-generaal Jörg dat de door de verdachte gebruikte bewoordingen op grond van de heersende zeden schennis van de eerbaarheid op-

ander daadwerkelijk wordt geconfronteerd, door het contact op internet te verbreken, kan er sprake zijn van een poging tot schennis van de eerbaarheid. Zie Hof Leeuwarden 27 maart 20I2, NJFS 20I2/II9. Art. 239 Sr omvat niet de situatie dat de dader het slachtoffer op een niet-openbare plaats heimelijk (naakt) afbeeldt (fotografeert of filmt). Voor die gevallen kunnen art. I39f en 44Ib Sr van toepassing zijn (HR I7 december 20I3, NJ 20I4/I49, m.nt. Keijzer), een misdrijf, respectievelijk overtreding tegen de openbare orde. Volgens de Rechtbank Gelderland is art. I39f Sr ook van toepassing in geval van heimelijk 'live' filmen van (naakte) personen. Onder verwijzing naar de wetsgeschiedenis van art. I39f (zie voetnoot 76 ) oordeelde deze rechtbank dat ook in dat geval het bestanddeel 'een afbeelding vervaardigt' wordt vervuld (Rb. Gelderland 29 augustus 20I6, ECLI:NL:RBGEL:20I6:480I).

I7I Kamerstukken II I979/80, I5 836, nrs. I-3, p. I3.

172 Lindenberg en Van Dijk 20I6, p. I38-I39.

I73 Lindenberg en Van Dijk 20I6, p. I42.

I74 Commissie zedelijkheidswetgeving I973, p. I2; Kamerstukken II I979/8o, I5 836, nr. 3, p. 8. 
leveren. Hij stelde dat art. 239 Sr ziet op 'directe confrontatie door en aan reëel aanwezige mensen', van welk gedrag in casu sprake was, ook al kon het slachtoffer de gedragingen van de verdachte niet zien. Jörg wees tevens op het 'overrompelingseffect' van verdachtes gedragingen. Sexting is volgens de advocaat-generaal dus strafbaar op grond van art. 239 Sr. De Hoge Raad oordeelde echter anders. Onder verwijzing naar de wetsgeschiedenis en de wetssystematiek, oordeelde hij dat schennis van de eerbaarheid door afbeelding of geschrift uitsluitend wordt beschermd door art. 240 Sr en art. 45I (oud) Sr. Laatstgenoemd artikel stelde onder meer strafbaar het in het openbaar zingen van voor de eerbaarheid aanstotelijke liederen. Met het intrekken van art. 45I $\mathrm{Sr}^{\mathrm{r} 75}$ heeft de wetgever niet beoogd de daarin strafbaar gestelde handelingen voortaan onder art. 239 Sr te laten vallen, zodat volgens de Hoge Raad moet worden aangenomen dat geen sprake kan zijn van schennis van de eerbaarheid door het gesproken woord. ${ }^{176}$ Sexting is volgens de Hoge Raad dus niet strafbaar op grond van art. 239 en $240 \mathrm{Sr} .{ }^{177} \mathrm{Hij}$ wees wel op de strafbaarstelling van belaging (art. $285 \mathrm{~b} \mathrm{Sr}$ ). ${ }^{178}$

\subsection{Belaging (art. 285b Sr)}

Art. 285b lid I Sr luidt als volgt:

'Hij, die wederrechtelijk stelselmatig opzettelijk inbreuk maakt op eens anders persoonlijke levenssfeer met het oogmerk die ander te dwingen iets te doen, niet te doen of te dulden, dan wel vrees aan te jaren wordt, als schuldig aan belaging, gestraft met een gevangenisstraf van ten hoogste drie jaren of een geldboete van de vierde categorie.'

Belaging is een misdrijf tegen de persoonlijke vrijheid, waarmee in het bijzonder de privacy of persoonlijke levenssfeer wordt bedoeld. De persoonlijke levenssfeer kan onmiddellijk of middellijk worden getroffen. ${ }^{179}$ Uit feitenrechtspraak blijkt dat onder belaging mede vallen gedragingen waarin stelselmatig met het slachtoffer wordt gecommuniceerd en daarbij seksueel getinte opmerkingen worden gemaakt (onmiddellijke belaging). ${ }^{180}$ In feitenrechtspraak is ook strafbaar geacht het met anderen stelselmatig in seksuele termen communiceren over het slachtoffer (middellijke belaging). ${ }^{18 \mathrm{I}}$ Een voorbeeld daarvan is het door de dader plaatsen van een advertentie op een datingsite waarbij deze zich daarin voordeed als het slachtoffer dat aangeeft seks te willen met andere personen. ${ }^{\text {I82 }}$ In deze gevallen is het slachtoffer ten tijde van de gedragingen niet op de hoogte van de belagende

I75 Wet van 3 juli 1985 , Stb. I985, 464 .

I76 Hetzelfde geldt voor art. $240 \mathrm{Sr}$. Zie Lindenberg 20I6, par. 2.

177 Lindenberg en Van Dijk 20I6, p. I43; Lindenberg 2016.

I78 HR 9 december 2003, NJ 2004/273, m.nt. Schalken.

I79 Kamerstukken II I997/98, 25 768, nr. 5, p. 2.

I80 Rb. Zutphen 24 maart 20I0, ECLI:NL:RBZUT:20I0:BL8824. Vgl. Rb. Rotterdam I7 februari 20I6, NJFS 20I6/86 waarin de verdachte op naam van aangeefster accounts aanmaakte op Twitter, Facebook en Instagram en daarop liefdesverklaringen, foto's en persoonlijke gegevens (van aangeefster) plaatste.

I8I Rb. Utrecht I3 april 20I2, ECLI:NL:RBUTR:20I2:BW43II.

I82 Rb. Limburg 23 oktober 20I3, ECLI:NL:RBLIM:2013:8002. Zie voor een iets andere casus Rb. Overijssel 2I maart 20I6, ECLI:NL:RBOVE:20I6:944. 
handelingen. Is er in dan toch sprake zijn van belaging? ${ }^{183}$ Op basis van een analyse van de wetsgeschiedenis van art. $285 \mathrm{~b} \mathrm{Sr}$ in een zaak waarin het slachtoffer na enige tijd op de hoogte raakte van verschillende belagingshandelingen van de verdachte, concludeerde advocaat-generaal Knigge dat ook sprake is van belaging wanneer het slachtoffer zich pas later bewust is geworden van de belagende handelingen. Ook uit rechtspraak van de Hoge Raad en enkele hoven leidde hij af dat 'momentane bewustheid' (bekendheid met de belagingshandelingen ten tijde van de handelingen) niet wordt vereist. Iets anders zou volgens hem tot 'allerhande haarkloverijen' leiden, hetgeen hij ongewenst achtte. Bekendheid bij het slachtoffer op het moment van de belagingshandelingen was volgens Knigge niet nodig, mits de dader ten tijde van de handelingen opzettelijk inbreuk maakte op de persoonlijke levenssfeer. Het oogmerkvereiste in art. 285b Sr maakt dit niet anders. Dat moet zo worden uitgelegd dat de gedragingen objectief een zekere ernst hebben. Wanneer de 'impact op het slachtoffer in potentie groot is' of 'de impact op het slachtoffer die het stelselmatig handelen redelijkerwijs kan hebben' (wat niet helemaal hetzelfde is, omdat de objectiviteitseis in het laatste citaat afhankelijk wordt gesteld van wat de redelijke mens vindt), zou aan het oogmerkvereiste zijn voldaan. ${ }^{184}$

Ook de Hoge Raad eist geen momentane bewustheid:

'Het oordeel van het Hof steunt op de opvatting dat een in art. 285b Sr omschreven gedraging uitsluitend dan als inbreuk makend op de persoonlijke levenssfeer van een ander kan worden aangemerkt indien deze nadien op de hoogte is gekomen van die gedraging. Die opvatting vindt evenwel geen steun in het recht en in het bijzonder niet in art. $285 \mathrm{~b} \mathrm{Sr}{ }^{3}{ }^{185}$

Opvallend is dat in het arrest van de Hoge Raad elke verwijzing naar het oogmerk ontbreekt, terwijl het daar volgens advocaat-generaal Knigge toch in niet onbelangrijke mate om ging. Dat de Hoge Raad hieraan geen aandacht besteedde, kan cassatietechnische redenen hebben; het zou ook kunnen betekenen dat de Hoge Raad aan het oogmerk weinig belang hecht indien blijkt dat de gedragingen stelselmatig wederrechtelijk opzettelijk inbreuk maakten op de persoonlijke levenssfeer. Een gedraging levert belaging op wanneer op basis van de wettige bewijsmiddelen de stelselmatige wederrechtelijke opzettelijke inbreuk op de persoonlijke levenssfeer is bewezen. ${ }^{186}$ Daar valt wat voor te zeggen. Het oogmerk voegt, in het licht van de overige in art. $285 \mathrm{~b}$ Sr opgenomen bestanddelen en met deze strafbaarstelling beschermde rechtsbelangen, weinig toe aan de strafwaardigheid van belaging.

$\overline{\mathrm{I} 83}$ J.M. Reijntjes meende dat, anders dan art. I26g Sv waaraan de term stelselmatig is ontleend, gelet op de verschillen tussen de opsporingsbevoegdheid in art. $126 \mathrm{~g}$ Sv en de strafbaarstelling van belaging in art. 285 b Sr, een 'ontkennend antwoord (...) voor de hand ligt'. Zie zijn annotatie onder HR I2 maart 2013, NJ 2013/395.

I84 A-G Knigge voor HR 4 november 20I4, NJ 20I5/48, m.nt. Reijntjes, punt 4.29-4.32.

I85 HR 4 november 20I4, NJ 2015/48, m.nt. Reijntjes.

I86 Vgl. het voorstel tot wijziging van art. $285 \mathrm{~b}$ Sr van J.M. Reijntjes in zijn annotatie onder HR I2 maart 20I3, NJ 20I3/395. Zie ook M.J.A. Duker, 'De reikwijdte van het belagingsartikel', RMThemis 2007, p. I44-I45. 
Een ander onderdeel van art. 285 b Sr dat bespreking behoeft, is het bestanddeel stelselmatig. Voor het antwoord op de vraag of de inbreuk op de persoonlijke levenssfeer stelselmatig geschiedt, zijn volgens de Hoge Raad van belang 'de aard, de duur, de frequentie en de intensiteit van de gedragingen, de omstandigheden waaronder die hebben plaatsgevonden en de invloed daarvan op de persoonlijke levenssfeer en de persoonlijke vrijheid van het slachtoffer' ${ }^{187}$ Aangenomen wordt dat deze omstandigheden als communicerende vaten ten opzichte van elkaar kunnen werken. Dat maakt maatwerk mogelijk. Het gaat volgens advocaat-generaal Hofstee uiteindelijk om het totaalbeeld dat uit de gedragingen van de verdachte valt af te leiden. ${ }^{188}$ De enkele sexting of sexchat, hoe indringend, tegen de wil van het slachtoffer en inbreuk makend op diens persoonlijke levenssfeer en persoonlijke vrijheid die ook moge zijn, levert op grond hiervan geen strafbare belaging op. ${ }^{189}$

\subsection{Seksuele gesprekken als voorfase van seksuele delicten (I)}

Uit rechtspraak blijkt dat sexting en sexchatting worden beschouwd als voorfase van seksuele delicten als verkrachting. ${ }^{190}$ Door sexting of sexchatting wordt iemand overgehaald, onder bedreiging of door verleiding, om seksuele handelingen te verrichten, met zichzelf of met een ander. Het blijft echter bij sexting of sexchatting. Zo was in verschillende zaken ten laste van de verdachte bewezenverklaard dat het slachtoffer was bedreigd. De bedreiging bestond er onder meer in dat via berichten op sociale media of door sms- of WhatsApp-berichten een ander onder druk was gezet om seksuele handelingen te verrichten. De kern van bedreiging (art. $285 \mathrm{Sr}$ ) is dat de gedraging van de verdachte 'van dien aard is en onder zodanige omstandigheden is geschied dat bij de bedreigde in redelijkheid de vrees kon ontstaan' dat het feit waarmee hij werd bedreigd zou plaatsvinden. ${ }^{191}$ In het geval van seksuele delicten moeten de uitingen van dien aard zijn dat daaruit kan worden afgeleid dat sprake is van bedreiging met verkrachting of feitelijke aanranding van de eerbaarheid (vgl. art. 285 lid I Sr). De bedreiging hoeft zich niet alleen te richten op het seksueel binnendringen van het lichaam; zij kan ook inhouden dat de ander ontuchtige handelingen met zichzelf voor een webcam moet verrichten. ${ }^{\text {192 }}$

Er kan pas sprake zijn van bedreiging als bij de bedreigde een redelijke (dat wil zeggen objectiveerbare) vrees kon ontstaan dat de strafbare feiten waarmee werd bedreigd door de bedreiger zullen worden gepleegd. Die vrees zal uit de bewoordingen moeten blijken. Bij sexting en sexchatting zal de grens tussen wat wel en niet onder bedreiging valt niet altijd eenvoudig zijn. ${ }^{193}$ De enkele opmerking 'Het enige wat ik met je wil is een baby maken' of 'Ik wil je neuken' kunnen objectief gezien niet worden beschouwd als bedreigend, zelfs al worden zij door de ontvanger van het bericht als onwenselijk beschouwd. Wanneer die opmerkingen gepaard

$\overline{I 87}$ HR 4 november 20I4, NJ 20I5/48, m.nt. Reijntjes; HR I2 maart 20I3, NJ 2013/394; HR I5 november 2005, Nieuwsbrief Strafrecht 2005/476; HR 29 juni 2004, NJ 2004/426, m.nt. De Jong.

I88 Conclusie A-G Hofstee voor HR I2 maart 2013, NJ 2013/393, punt Io.

I89 Vgl. Kamerstukken I I999/2000, 25 768, nr. 67a, p. 5 .

I9o Lindenberg en Van Dijk 2016, p. I26-I29.

I9I T\&C Sr, aant. 8a bij art. 285.

I92 Rb. Rotterdam 8 oktober 20I4, ECLI:NL:RBROT:20I4:8074.

I93 Soms wel: zie Rb. Haarlem 30 september 2008, ECLI:NL:RBHAA:2008:BF7III. 
gaan met 'Ik doorboor jou [sic] focking hart' of 'Ik pak je wel persoonlijk' en 'Ik zal je hebben', leveren zij in onderlinge samenhang beschouwd wel bedreigingen op. ${ }^{194}$ Sexting en sexchatting zijn dus tot op zekere hoogte met behulp van bedreiging strafrechtelijk aan te pakken.

Bedreigende opmerkingen via sociale media worden ook gebruikt voor het bewijs van poging tot feitelijke aanranding van de eerbaarheid (art. 45 jo. $246 \mathrm{Sr}$ ). Uit de door de verdachte met slachtoffers gevoerde gesprekken moet kunnen worden afgeleid het voornemen om ontuchtige handelingen te plegen. Daarbij ging het in de gevonden feitenrechtspraak bijvoorbeeld om gedragingen (voor een webcam) die slachtoffers bij zichzelf zouden moeten verrichten of van de verdachte zouden moeten dulden. In deze zaken werd tevens een begin van uitvoering aangenomen, in het bijzonder omdat een deel van de delictsomschrijving door de verdachte was vervuld. Er werd bijvoorbeeld (meermalen) gedreigd met fysiek geweld tegen (onder andere) het slachtoffer met als doel het slachtoffer ontuchtige handelingen met zichzelf te laten plegen. ${ }^{195}$ Het dreigen met een andere feitelijkheid werd aangenomen door het dreigen (compromitterende) foto's van het slachtoffer op het internet te plaatsen. ${ }^{196}$ De gesprekken die de verdachte met het slachtoffer via sociale media voerde, mondden telkens niet uit in ontuchtige handelingen. Dat de gesprekken wel dat doel hadden en zij met bedreiging met geweld of enige feitelijkheid gepaard gingen, betekent dat de gesprekken als poging tot feitelijke aanranding van de eerbaarheid strafbaar kunnen zijn.

De relatie tussen bedreiging en poging tot feitelijke aanranding van de eerbaarheid is gelet op de voorhanden zijnde rechtspraak niet zonder meer duidelijk. De veroordelingen wegens bedreiging lijken ook een poging tot feitelijke aanranding van de eerbaarheid te kunnen opleveren. Het laat zich in die gevallen niet eenvoudig raden waarom het Openbaar Ministerie bij de vervolgingsbeslissing in het ene geval voor bedreiging en in het andere voor poging tot feitelijke aanranding van de eerbaarheid koos. ${ }^{\text {I97 }}$ Van belang zou kunnen zijn dat de zaken waarin bedreiging ten laste was gelegd niet alleen zagen op seksuele delicten, maar ook op (andere) geweldsdelicten. Indien de bedreiging op meer strafbare feiten is gericht dan alleen seksuele delicten, of niet zonder meer duidelijk is of de bedreiging op het plegen van seksuele delicten was gericht, dan ligt vervolging wegens bedreiging meer voor de hand. Wanneer de bedreiging slechts (of in het bijzonder) op seksuele delicten is gericht, dan lijkt het gelet op het flinke verschil in strafmaximum

I94 Rb. Overijssel I8 september 20I4, ECLI:NL:RBOVE:20I4:4938; Rb. Gelderland 22 april 20I4, ECLI:NL:RBGEL:20I4:2698.

I95 Rb. Overijssel 2 februari 20I6, ECLI:NL:RBOVE:20I6:3II; Rb. Roermond 22 april 20II, ECLI:NL: RBROE:20II:BQ3544; Rb. 's-Gravenhage 9 september 20I0, ECLI:NL:RBSGR:2010:BN6376.

I96 Rb. Arnhem II oktober 20I2, ECLI:NL:RBARN:20I2:BX9930.

I97 In feitenrechtspraak heb ik geen voorbeelden gevonden waarin dezelfde gedragingen werden tenlastegelegd als poging tot feitelijke aanranding van de eerbaarheid en bedreiging. Ondenkbaar hoeft dat niet te zijn. Aangenomen mag worden dat in dat geval sprake zal zijn van meerdaadse samenloop (art. $57 \mathrm{Sr}$ ), omdat de strekking van beide strafbare feiten verschilt. Evenmin zal het voor de hand liggen dat er sprake is van hetzelfde feit in de zin van art. $68 \mathrm{Sr}$, zodat vervolging voor het ene feit er niet aan in de weg staat daarna te vervolgen voor het andere feit. Zie over samenloop en hetzelfde feit A.A. Franken, Hetzelfde feit. Over samenloop van strafbare feiten en het non bis in idem-beginsel, Nijmegen: Ars Aequi Libri 1995 . 
(en daarmee het verwijt) meer voor de hand te liggen wegens poging tot feitelijke aanranding van de eerbaarheid te vervolgen..$^{\mathrm{I} 8}$

\subsection{Seksuele gesprekken als voorfase van seksuele delicten (II)}

De vraag die in de rechtspraak aan de orde is gekomen, is of sexchatting voldoende is voor een poging tot verleiding als bedoeld in art. 248a Sr. Het voornemen om ontuchtige handelingen te plegen of van de verdachte te dulden kan, zo blijkt uit rechtspraak, uit gesprekken via sociale media worden afgeleid. ${ }^{199}$ Die gesprekken volstaan op zichzelf echter niet om daaruit een begin van uitvoering van ontuchtige handelingen af te leiden. ${ }^{200}$ Daarvoor zijn andere, concrete gedragingen nodig. Concrete gedragingen zijn het geven van giften (geld, sieraden, kleding, sigaretten) of doen van beloften (geld of drugs), of een combinatie van beide. ${ }^{201}$ Is er naast die concrete gedragingen nog meer nodig, bijvoorbeeld een min of meer concreet voorstel tot het plegen of dulden van ontuchtige handelingen? De Rechtbank Rotterdam achtte het sturen van sms-berichten en het vragen om een foto van het slachtoffer in bikini zonder een concreet voorstel tot ontmoeting niet voldoende om van een poging tot het misdrijf in art. 248a Sr te spreken. ${ }^{202}$ Het Hof Den Haag achtte het door een leraar tijdens een chatgesprek aandringen op ontuchtige handelingen door een leerlinge echter wel voldoende voor een begin van uitvoering, vermoedelijk omdat het de bedoeling van de verdachte was dat de ontuchtige handelingen onmiddellijk op zijn aandringen via een webcam moesten volgen. ${ }^{203}$ In andere gevallen werden de giften en het doen van beloften zonder dat sprake is van een min of meer concreet voorstel tot ontmoeting beschouwd als begin van uitvoering, zolang kon worden aangenomen en ook voor het slachtoffer duidelijk was dat voor de giften en beloften een tegenprestatie moest worden geleverd in de vorm van ontuchtige handelingen. ${ }^{204}$ Dat die tegenprestatie in die gevallen op zich kon laten wachten, maakte met het bewezen voornemen voor het aannemen van een begin van uitvoering van het misdrijf van art. 248a Sr evenwel niet uit. Dat kan de afstand tussen poging en voltooiing van het delict behoorlijk groot maken.

I98 Poging tot feitelijke aanranding van de eerbaarheid kan worden bestraft met gevangenisstraf van maximaal vijf jaar en vier maanden (acht jaar min een derde (art. 246 jo. 45 lid 2 Sr)) of een geldboete van maximaal $€ 8$ I.00o; bedreiging kan worden bestraft met gevangenisstraf van maximaal twee jaar (art. $285 \mathrm{Sr}$ ) of een geldboete van maximaal $€ 20.250$.

199 Rb. Den Haag 8 december 20I5, ECLI:NL:RBDHA:20I5:I4076; Rb. Noord-Nederland 3I maart 20I5, ECLI:NL:RBNNE:2015:1580; Hof Den Haag I december 2014, ECLI:NL:GHDHA:20I4:3380; Hof Arnhem 25 maart 20I0, ECLI:NL:GHARN:20I0:BL9478.

200 Rb. Den Haag 8 december 20I5, ECLI:NL:RBDHA:20I5:I4076; Hof 's-Hertogenbosch II maart 20I3, ECLI:NL:GHSHE:2013:CA3698.

201 Rb. Den Haag 8 december 20I5, ECLI:NL:RBDHA:20I5:I4076; Rb. Oost-Brabant 25 september 20I5, ECLI:NL:RBOBR:2015:5529; Rb. Oost-Brabant 9 december 20I4, ECLI:NL:RBOBR: 20I4:7494; Rb. Noord-Nederland 3I maart 20I5, ECLI:NL:RBNNE:20I5:I580; Rb. Noord-Nederland Io juli 20I4, ECLI:NL:RBNNE:20I4:336I; Rb. Noord-Holland 2I maart 20I3, ECLI:NL: RBNHO:20I3:808I; Hof Arnhem 25 maart 20I0, ECLI:NL:GHARN:20Io:BL9478.

202 Rb. Oost-Brabant 9 december 20I4, ECLI:NL:RBOBR:20I4:7494. Vgl. Rb. Noord-Nederland Io juli 20I4, ECLI:NL:RBNNE:20I4:336I; Hof Den Haag I8 maart 20I4, ECLI:NL:GHDHA: 20I4:907; Rb. Middelburg I december 2010, ECLI:NL:RBMID:2010:BW2976.

203 Hof Den Haag I december 20I4, ECLI:NL:GHDHA:20I4:3380.

204 Hof Arnhem-Leeuwarden 8 december 20I5, ECLI:NL:GHARL:2015:992I; Rb. Den Haag 8 december 2015, ECLI:NL:RBDHA:2015:I4076; Rb. Noord-Nederland 31 maart 2015, ECLI:NL: RBNNE:2015:1580; Rb. Noord-Holland 2I maart 2013, ECLI:NL:RBNHO:2013:808I; Hof Arnhem 25 maart 20IO, ECLI:NL:GHARN:20I0:BL9478. 
Wanneer deze ruime omschrijving zou worden gevolgd - de tekst van de wet lijkt zich daar in ieder geval niet tegen te verzetten - dan kunnen vragen worden gesteld over de verhouding tussen art. $248 \mathrm{a}$ Sr en art. $248 \mathrm{e}$ Sr dat grooming strafbaar stelt (zie par. 6.7).

\section{$6 \quad$ Grooming}

\section{I Internationale herkomst}

Eerder in dit preadvies werd verwezen naar Richtlijn 20II/93/EU waarin lidstaten wordt opgedragen grooming strafbaar te stellen. De definitie van grooming daarin luidt (art. 6 lid I): het met opzet

'doen van een voorstel door middel van informatie- en communicatietechnologie, door een volwassene aan een kind dat nog niet seksueel meerderjarig is, tot ontmoeting met het oogmerk om een van de in artikel 3 , lid 4 , en artikel 5 , lid 6, genoemde strafbare feiten te plegen, wordt, voor zover dit voorstel is gevolgd door materiële handelingen die tot een dergelijke ontmoeting leiden, gestraft met een maximumgevangenisstraf van ten minste één jaar'.

In de preambule bij de Richtlijn wordt het belang van strafbaarstelling van grooming (zowel op internet (online grooming) al daarbuiten (offline grooming)) benadrukt. Art. 6 lid I ziet alleen op online grooming. Een regeling van grooming werd ook voorgesteld in het eerder genoemde Verdrag van de Raad van Europa inzake de bescherming van kinderen tegen seksuele uitbuiting en seksueel misbruik (Verdrag van Lanzarote). Art. 23 van het Verdrag luidt:

'Elke Partij neemt de wetgevende of andere maatregelen die nodig zijn voor het strafbaar stellen van het doen van een voorstel, door middel van informatie- en communicatietechnologie, door een volwassene aan een kind (...) tot een ontmoeting met als vooropgezet doel het plegen van een overeenkomstig artikel I8, eerste lid, onderdeel a, of artikel 20, eerste lid, onderdeel a, strafbaar gesteld feit tegen hem of haar, wanneer dit voorstel is gevolgd door materiële handelingen die tot een dergelijke ontmoeting leiden.'

Ook het Verdrag beperkt zich tot online grooming. Zowel de Richtlijn als het Verdrag gaat uit van een meerderjarige dader en een minderjarig slachtoffer. In de Richtlijn is iedere persoon jonger dan achttien jaar een kind, in het Verdrag is het ten aanzien van de strafbaarstelling van onder andere grooming aan de lidstaten overgelaten tot welke leeftijd gesproken wordt van een kind. Anders dan het Verdrag wordt in de Richtlijn het opzet op het doen van een voorstel uitdrukkelijk vermeld. In beide regelingen is het opzet in ieder geval gericht op het plegen van (verschillende vormen van) seksueel misbruik. In de Nederlandse vertaling wordt gesproken van 'oogmerk' en 'vooropgezet doel'. In beide gevallen zien zij op het aangaan van seksuele handelingen met een kind dat nog niet seksueel meerderjarig is (art. I8 lid I respectievelijk art. 3 lid 4) en het vervaardigen van kinderpornografie (art. 20 lid I respectievelijk art. 5 lid 6). De strafbaarstelling wordt (verder) beperkt doordat het voorstel moet zijn gevolgd 'door materiële handelingen die tot 
een dergelijke ontmoeting leiden'. Het enkele voorstel levert met andere woorden geen strafbare grooming op. Uit de beide regelingen volgt overigens niet dat het voorstel tot een ontmoeting en de handelingen die tot een dergelijke ontmoeting moeten leiden tegen de wil van het kind zijn gedaan. In het Verdrag wordt elke vorm van online grooming afgekeurd. In overweging 20 van de preambule van de Richtlijn worden enkele gevallen uitgezonderd. Uit de omschrijving van grooming in het Verdrag volgt dat het doel van de groomer moet zijn het plegen van offline ontuchtige handelingen door de groomer ('tegen hem of haar'). De tekst van de Richtlijn lijkt niet uit te sluiten dat grooming ook tot doel kan hebben het plegen van online ontuchtige handelingen door het slachtoffer.

\subsection{De door strafbaarstelling van grooming beschermde rechtsbelangen}

De in overweging 20 opgenomen beperking neemt niet weg dat grooming wordt beschouwd als een 'ernstige schending van de grondrechten, in het bijzonder van de rechten van kinderen en voor hun welzijn noodzakelijke bescherming en zorg' (overweging I van Richtlijn 20II/93/EU). In het Verdrag van Lanzarote worden in de preambule 'het welzijn en de belangen van kinderen fundamentele waarden' genoemd. Tevens wordt daarin aangegeven dat seksuele uitbuiting en seksueel misbruik van kinderen 'zeer schadelijke gevolgen hebben voor de gezondheid van kinderen en hun psychosociale ontwikkeling'.

De Nederlandse wetgever verwees bij de invoering van de strafbaarstelling van grooming (art. 248e Sr) allereerst naar de wens om kinderen te beschermen. ${ }^{205}$ In literatuur is over de strafbaarstelling van grooming gesteld dat (ook) schade een rechtvaardiging daarvan vormt. Schade wordt omschreven als 'negatieve gevolgen' voor minderjarige personen, die door de dader is aangericht 'door het chatten en seksuele toespelingen maken voor wat betreft de afspraak'. ${ }^{206}$ In de memorie van toelichting is grooming een nieuwe vorm van misbruik (digitaal misbruik) en een 'maatschappelijk zeer schadelijk' verschijnsel genoemd. ${ }^{207}$ Kool stelt daarentegen dat bij grooming geen sprake is van schade. Zij spreekt van een 'gevaar op krenkingen van rechtsbelangen, in dit geval het recht van de minderjarige op een ongehinderde seksuele ontplooiing'. ${ }^{208}$ Het verwijt komt volgens haar neer op het 'misbruik maken van de mogelijkheden die digitale communicatietechnologieën in combinatie met een gebrek aan (ouderlijk) toezicht bieden'. ${ }^{209}$ Het verwijt is zo bezien dus dat schade kan worden gerealiseerd als gevolg van gedragingen die op zichzelf misschien niet zonder meer schadelijk zijn. Deze omschrijving sluit aan bij de wetsgeschiedenis, waarin onderscheid wordt gemaakt tussen digitaal en fysiek misbruik. Het digitale misbruik stelde de wetgever voor als voorbereiding van

205 Kamerstukken II 2008/o9, 3I 810, nr. 3, p. 6.

206 A.R. Lodder, 'Grooming: over meerderjarigen die internet en jeugdigen misbruiken', Tijdschrift voor Internetrecht 2015, p. 57, 62.

207 Kamerstukken II 2008/o9, 3I 8Io, nr. 3, p. 2; Kamerstukken II 2015/16, 34 372, nr. 3, p. 4.

208 Zie ook F.P. Ölçer, 'De lokmethode bij de opsporing van grooming', Computerrecht 20I4/3, par. I, die stelt dat het gevaar wordt vergroot doordat grooming in een online context plaatsvindt. Daardoor wordt controle door ouders en verzorgers en anderen bemoeilijkt.

209 Kool 20Io, par. 4.I en 5. Vgl. Van der Hof en Koops 20II, p. 5-9; S. van der Hof, 'Online grooming - een geval van technopaniek?', Strafblad 20I4, p. 22; J. Hornle, 'Countering the Dangers of Online Pornography - Shrewd Regulation of Lewd Content', European Journal of Law and Technology 20II, p. 4-5. 
het 'daadwerkelijke seksueel misbruik'. ${ }^{210}$ Spreekt de wetgever zichzelf hier tegen? Dat gaat misschien wat ver. Maatschappelijke schade lijkt niet hetzelfde te zijn als aan een persoon toe te brengen schade. Dat neemt niet weg dat de wetgever allesbehalve helder is in de precieze omschrijving van de in het geding zijnde rechtsbelangen. Aangenomen moet worden dat grooming zelf geen schade (in de zin van de daadwerkelijke krenking van rechtsbelangen van derden) teweegbrengt. In dat geval zou de wetgever namelijk niet goed kunnen volhouden dat grooming een voorbereidingsdelict is. ${ }^{211}$ Een dergelijk delict stelt strafbaar het voorbereiden van het toebrengen van schade, niet het daadwerkelijk toebrengen van schade.

Het belang van het voorgaande is dat de enkele seksuele communicatie met een minderjarige niet schadelijk en daarom niet strafbaar is. Er moet sprake zijn van een schadelijk doel, waarvan een begin van verwezenlijking uit de handelingen van de dader kan worden afgeleid. Zonder dat doel en handelingen ter verwezenlijking van dat doel is er geen strafbare grooming. Zou de enkele sexchat met minderjarigen reeds schadelijk worden geacht, dan zou het opnemen van een doel in de strafbaarstelling overbodig zijn geweest. Zover wilde de wetgever blijkbaar niet gaan.

\subsection{Omschrijving van de strafbaarstelling van grooming naar Nederlands recht (art. 248e Sr)}

Hoewel de Richtlijn noch het verdrag de Nederlandse wetgever verplichtte grooming in een aparte strafbaarstelling op te nemen, heeft deze daar om verschillende redenen wel voor gekozen. Aparte strafbaarstelling werd wenselijk geacht omdat grooming in zowel de Richtlijn als het Verdrag specifiek wordt omschreven, er grote zorgen bestonden over dit 'snelgroeiend en zorgwekkend fenomeen', de (strafrechtelijke) aanpak gebaat zou zijn bij een 'duidelijke omschrijving van het strafbare gedrag', van aparte strafbaarstelling een 'signaalwerking' zou uitgaan en op 'eenduidige wijze' uitvoering werd gegeven aan de internationale verplichtingen tot strafbaarstelling van grooming. ${ }^{212}$ De eenduidige wijze van uitvoering heeft de wetgever er niet van weerhouden de delictsomschrijving van grooming iets anders vorm te geven, in vergelijking tot de definitie in zowel de Richtlijn als het Verdrag. Art. 248e Sr luidt:

'Hij die door middel van een geautomatiseerd werk of met gebruikmaking van een communicatiedienst een persoon van wie hij weet of redelijkerwijs moet vermoeden dat deze de leeftijd van zestien jaar nog niet heeft bereikt, een ontmoeting voorstelt met het oogmerk ontuchtige handelingen met die persoon te plegen of een afbeelding van een seksuele gedraging waarbij die persoon betrokken is, te vervaardigen wordt, indien hij enige handeling onderneemt gericht op het verwezenlijken van die ontmoeting, gestraft met gevangenisstraf van ten hoogste twee jaren of geldboete van de vierde categorie.'

2Io Kamerstukken II 2008/o9, 3I 8Io, nr. 3, p. 6, 7, 9.

2 II Kamerstukken II 2008/o9, 3I 8Io, nr. 3, p. 9; Kamerstukken II 2008/o9, 3I 8Io, nr. 7, p. 8.

2 I2 Kamerstukken II 2008/og, 3I 8Io, nr. 3, p. 7. 
Niet onbelangrijk is dat grooming naar Nederlands recht, anders dan in het Verdrag en de Richtlijn, ook door minderjarigen kan worden gepleegd. ${ }^{213}$ Met betrekking tot de bestanddelen 'ontmoeting voorstelt' is tijdens de totstandkoming van art. 248 e Sr opgemerkt dat daarmee duidelijk wordt gemaakt dat de enkele seksuele communicatie (consensueel of niet) niet strafbaar is. ${ }^{214}$ Een voorstel tot een ontmoeting onderstreept 'de vastheid van het voornemen van de dader om zijn digitaal misbruik daadwerkelijk om te zetten in het plegen van fysiek misbruik'. ${ }^{215}$ Weliswaar hoeft dat misbruik niet plaats te vinden, zonder een voorstel tot ontmoeting is van grooming geen sprake. Het voorstel kan geconcretiseerd zijn, al is dat volgens de wetgever niet vereist. ${ }^{216}$ Ten aanzien van het bestanddeel 'enige handeling onderneemt gericht op het verwezenlijken van die ontmoeting' spreekt de minister van 'concrete voorbereidingen (...) gericht op het verwezenlijken van die ontmoeting'. Het zich begeven 'naar de voor de ontmoeting afgesproken plek, het slachtoffer van een routebeschrijving naar die plek' voorzien en 'het kopen van treinkaartjes of toegangsbewijzen die verband houden met de voorgenomen ontmoeting' waren volgens de minister van Justitie voorbeelden van concrete voorbereidingen. ${ }^{217}$ Dit contrasteert met de uitleg die van het voorstel werd gegeven, omdat het voorstel niet concreet hoeft te zijn, terwijl wel concrete voorbereidingen voor het verwezenlijken van die ontmoeting worden vereist. Hoewel concrete voorbereidingen van een niet concreet voorstel mogelijk zijn, ligt het toch meer voor de hand dat die voorbereidingen pas echt concreet kunnen zijn (gericht op verwezenlijking van die ontmoeting), wanneer het voorstel ook (min of meer) concreet is. Lindenberg en Van Dijk wijzen er ook op dat de inhoud van de voorbereidingshandelingen volgens de Nederlandse wetgever minder concreet hoeven te zijn dan de voorbeelden die in het explanatory report bij het Verdrag zijn aangegeven. Daarin zijn de voorbereidingshandelingen vrij concreet omschreven, namelijk het aankomen op de plaats van de ontmoeting (die kennelijk concreet is omschreven). ${ }^{218}$ De door de minister van Justitie gegeven voorbeelden wijzen op handelingen die verder van de ontmoeting zijn gelegen. Dat laat zich verklaren doordat grooming expliciet als voorbereidingsdelict wordt omschreven. Grooming slechts strafbaar te achten wanneer de dader aankomt op de plaats van de ontmoeting, maakt van grooming eerder een pogingsdelict en bemoeilijkt de rechtvaardiging van de invoering van een aparte strafbaarstelling ten opzichte van de reeds bestaande poging tot verleiding (art. 45 jo. $248 \mathrm{a} \mathrm{Sr}$ ). Met art. $248 \mathrm{e}$ Sr wilde de minister eerder kunnen ingrijpen dan volgens hem met poging tot verleiding mogelijk was. ${ }^{219}$ Wanneer de bestanddelen van de delictsomschrijving van art. $248 \mathrm{e} \mathrm{Sr}$ al te strikt

2I3 Ten aanzien van grooming tussen minderjarigen wordt aangenomen dat consensuele handelingen buiten het bereik van deze strafbaarstelling vallen. Zie Kool 2oro, par. 4.I. Dat blijkt weliswaar niet uit de wettelijke bepaling, maar rechtspraak over consensueel seksueel contact tussen minderjarigen laat zien dat dergelijke gedragingen wellicht naar de letter, maar niet altijd naar de geest van de wet strafbaar zijn. Zie HR 30 maart 20I0, NJ 2010/376, m.nt. Keijzer; HR 9 februari 20I6, NJ 20I6/257, m.nt. Rozemond. Zie ook J.W. Gooren, 'Over de bestraffing van ontucht met instemming van jongeren', Proces 2009, p. 220-235.

2 I4 Kamerstukken II 2008/o9, 3I 808 (RI872), nr. 3, p. I3.

2 I5 Dit maakt overigens duidelijk dat art. 248 e Sr enkel ziet op offline ontuchtige handelingen. Dit blijkt ook uit de wettekst, door het gebruik van het woordje 'met'.

2 I6 Kamerstukken II 2008/09, 3I 8IO, nr. 3, p. 6-7; Kamerstukken II 2008/o9, 3I 8Io, nr. 7, p. 7-8.

217 Kamerstukken II 2008/09, 3I 8Io, nr. 3, p. 7; Kamerstukken II 2008/09, 3I 8Io, nr. 7, p. 8.

2 I8 Lindenberg en Van Dijk 20I6, p. I8I-I82.

2I9 Vgl. Kamerstukken II 2008/o9, 3I 8Io, nr. 3, p. 6, 7. 
zouden worden uitgelegd, zou deze wens volgens de minister niet (goed) kunnen worden vervuld.

De tekst van art. 248e Sr verzet zich niet tegen strafbaarheid van op het eerste gezicht vrij onschuldige seksuele communicatie met een minderjarige die tot een voorstel tot een ontmoeting leidt en handelingen gericht op het verwezenlijken van die ontmoeting mits met het oogmerk om ontuchtige handelingen te plegen of kinderpornografie te vervaardigen. ${ }^{220}$ Ook de handelingen ter verwezenlijking van de ontmoeting kunnen op zichzelf vrij onschuldig zijn. De combinatie van onschuldige seksuele communicatie en onschuldige handelingen ter verwezenlijking van een ontmoeting wijst erop dat nadruk ligt op het opzet (het doel van de ontmoeting). Dat opzet (oogmerk) moet blijkens de tekst van art. 248e Sr aanwezig zijn op het moment dat het voorstel tot een ontmoeting wordt gedaan en ziet op het ontmoeten van de persoon waarmee gecommuniceerd is. Dat tussen het voorstel en de uitvoering (de handelingen gericht op verwezenlijking van de ontmoeting) enige tijd gelegen kan zijn, maakt het mogelijk dat de dader in de tussentijd tot inkeer komt. In het geval de dader geen handeling onderneemt gericht op verwezenlijking van de ontmoeting, is er geen sprake van grooming. Indien hij echter wel een dergelijke handeling onderneemt en vervolgens tot inkeer komt, staat de wet noch de totstandkomingsgeschiedenis eraan in de weg hem niettemin wegens grooming te veroordelen. ${ }^{221}$

De strafbaarstelling van grooming roept een drietal vragen op. De eerste vraag is of de gedragingen moeten zijn gericht op 'echte' kinderen. De strafrechtelijke aanpak van seksueel misbruik op het internet heeft tot de ontwikkeling van nieuwe opsporingsmethoden geleid. In het bijzonder kan daarbij worden gedacht aan de 'lokpuber'. Dit fenomeen heeft verschillende gedaantes: het gaat om communicatie met een potentiële groomer door een ander die geen minderjarige is, maar een opsporingsambtenaar of de ouder of verzorger van het kind waarmee in eerste instantie contact was gelegd, of om communicatie met een potentiële groomer door een ander die slechts in de virtuele werkelijkheid bestaat (zoals 'Sweetie', een voor Terre des Hommes ontwikkeld fictief Filipijns meisje dat was gemaakt om potentiële kindermisbruikers te lokken). ${ }^{22}$ De lokpuber riep procesrechtelijke ${ }^{223}$ en materieelrechtelijke vragen op. Is er wel sprake van grooming wanneer de minderjarige met wie is gecommuniceerd en aan wie een ontmoeting is voorgesteld geen minderjarige is, maar een meerderjarige of slechts in de virtuele wereld bestaat? De tweede vraag is of poging tot grooming strafbaar is. Deze vraag heeft in de rechtspraktijk tot wisselende antwoorden geleid. Een onderdeel van deze vraag is of vrijwillige terugtred (inkeer) bij grooming mogelijk is. Beide vragen zijn inmiddels door de wetgever geadresseerd. De derde vraag is wanneer sprake is van het ondernemen van 'enige handeling (...) gericht op het verwezenlijken van die ontmoeting'. Hierover bestaat rechtspraak van de Hoge Raad, terwijl ook de wetgever zich dit punt heeft aangetrokken.

220 R.S.B. Kool, 'Prevention by All Means? A Legal Comparison of the Criminalization of Online Grooming and Its Enforcement', Utrecht Law Review 20II, p. 62.

22I Kool 20I0, par. 5; Lodder 2015, p. 62.

222 Aanhangsel van de Handelingen II 20I3/I4, nr. 643.

223 Zie Ölçer 20I4; S.F.J. Smeets, 'De “lokpuber”: een mislukt experiment', Strafblad 20I3, p. 332-338. 


\subsection{Grooming met alleen 'echte' kinderen?}

Art. $248 \mathrm{e}$ Sr bepaalt dat het voorstellen van een ontmoeting moet geschieden met een persoon van wie de dader weet of redelijkerwijs moet vermoeden dat die de leeftijd van zestien jaren nog niet heeft bereikt. Het kind waarmee werd gecommuniceerd en waaraan een ontmoeting werd voorgesteld moet hetzelfde kind zijn. ${ }^{224}$ De in art. 248e Sr genoemde leeftijd was volgens de minister een 'objectieve leeftijd'. Dat vloeide volgens hem voort uit het Verdrag, dat beoogt minderjarigen te beschermen. ${ }^{225}$ Daaruit werd in rechtspraak afgeleid dat contact met een persoon (een opsporingsambtenaar) die zich voordeed als minderjarige, maar in werkelijkheid ouder was dan zestien jaar (de zogeheten lokpuber), geen strafbare grooming oplevert. ${ }^{226}$ De minister van Veiligheid en Justitie bevestigde deze lezing van art. $248 \mathrm{e}$ Sr en kondigde aan dat de wet op dit punt te herzien. ${ }^{27}$ Het onlangs voorgestelde nieuwe art. 248e Sr zal als volgt komen te luiden:

'Hij die door middel van een geautomatiseerd werk of met gebruikmaking van een communicatiedienst aan een persoon die de leeftijd van zestien jaren nog niet heeft bereikt of iemand die zich voordoet als een persoon die de leeftijd van zestien jaren nog niet heeft bereikt een ontmoeting voorstelt met het oogmerk ontuchtige handelingen met een persoon die de leeftijd van zestien jaren nog niet heeft bereikt te plegen of een afbeelding van een seksuele gedraging waarbij een persoon die de leeftijd van zestien jaren nog niet heeft bereikt is betrokken te vervaardigen, wordt, indien hij enige handeling onderneemt tot het verwezenlijken van die ontmoeting, gestraft met gevangenisstraf van ten hoogste twee jaren of een geldboete van de vierde categorie. ${ }^{228}$

Met de nieuwe omschrijving van art. 248e Sr wordt het mogelijk personen te bestraffen wegens grooming, ook wanneer de persoon met wie een ontmoeting wordt voorgesteld in werkelijkheid ouder is dan zestien jaar. ${ }^{229}$ De wijziging wordt wenselijk geacht, omdat anders 'ernstig afbreuk' wordt gedaan 'aan de bescherming van kinderen tegen grooming'. ${ }^{230}$ De bescherming wordt wel van een concreet kind geabstraheerd. De omstandigheid dat er personen zijn die van het internet gebruikmaken om contact te leggen met personen van wie zij denken dat

224 Kamerstukken II 2008/o9, 3i 8Io, nr. 3, p. 6.

225 Kamerstukken II 2008/09, 3I 808, nr. 6, p. I2.

226 Hof Den Haag 25 juni 20I3, NJ 20I4/I23; Rb. 's-Gravenhage, I4 september 20I2, NJFS 20I2/228; Rb. Amsterdam II april 20II, ECLI:NL:RBAMS:20II:BQog6I.

227 Aanhangsel van de Handelingen II 2013/I4, nr. 643.

228 Kamerstukken II 20I5/I6, 34 372, nr. 2.

229 Kamerstukken II 20I5/I6, 34 372, nr. 3, p. 4. Zonder toelichting wordt virtuele grooming (grooming van een alleen in de virtuele wereld bestaand persoon) kennelijk niet strafbaar gesteld. Het ligt ook niet voor de hand om virtuele grooming op basis van de voorgestelde wettekst strafbaar te achten, tenzij 'iemand die zich voordoet als een persoon' ook kan worden uitgelegd als schijnbaar iemand. De memorie van toelichting geeft geen aanleiding deze extensieve interpretatie van dit onderdeel van het nieuwe art. $248 \mathrm{e}$ Sr toe te laten. In de literatuur (genoemd in voetnoot 67 ) wordt in meer algemene zin tegen een dergelijke uitbreiding van de zedenwetgeving gewaarschuwd. Het is echter de vraag of de met grooming te beschermen rechtsbelangen (en de hierna nog te bespreken nadere invulling daarvan) grooming van een virtueel persoon uitsluit. Dat lijkt mij niet het geval. Een en ander betekent wel dat wettekst en rechtsbelangen (opnieuw) niet op elkaar aansluiten. Het zou de wetgever sieren ook op dit punt meer duidelijkheid te verschaffen.

230 Kamerstukken II 20I5/I6, 34 372, nr. 3, p. 69. 
zij minderjarig zijn en vervolgens een ontmoeting met hen voorstellen, levert objectief gezien geen gevaar voor schade voor een concreet kind op. De minister vermijdt echter naar schade te verwijzen. Het gaat hem om het doel kinderen te beschermen. Niet duidelijk is echter hoe kinderen worden beschermd door het opnemen van de lokpuber ${ }^{23}$ in de wet. Het College van Procureurs-Generaal heeft in een advies aan de minister aangegeven dat de bescherming van kinderen het 'onwenselijk' maakt dat kinderen het gevaar lopen te worden benaderd door iemand die hen wil ontmoeten met het doel die kinderen te misbruiken. ${ }^{232}$ Verruiming van de strafbaarstelling van grooming was volgens het College nodig om te voorkomen dat kinderen in contact treden met een persoon die hen zou willen misbruiken. Het gevaar dat iemand in contact treedt met een lokpuber en een ontmoeting voorstelt en die wil verwezenlijken levert kennelijk het gevaar op dat deze persoon een echt kind wil ontmoeten en die ontmoeting wil verwezenlijken, wat het gevaar voor misbruik of het maken van kinderporno van dat kind oplevert. Waar het bij grooming van echte kinderen gaat om het gevaar voor misbruik, geldt in het geval van grooming van personen die zich voordoen als zestienminner dat het gevaar bestaat dat groomers met echte zestienminners een voorstel tot ontmoeting willen doen en die ontmoeting willen verwezenlijken. Het gaat dus niet alleen om het gevaar voor seksueel misbruik, maar ook om het gevaar voor communicatie met echte kinderen (op internet) waarin een voorstel tot een ontmoeting wordt gedaan. Dat gevaar ligt verder af van het seksueel misbruik dan het gevaar voor seksueel misbruik dat zich kan manifesteren wanneer een ontmoeting wordt verwezenlijkt. De minister lijkt zich daarvan bewust en verwijst ter ondersteuning van de voorgenomen wetswijziging naar de argumenten om virtuele kinderporno strafbaar te stellen (par. 2.3). In het bijzonder verwijst hij daarbij naar de wens om een 'subcultuur die seksueel misbruik van kinderen bevordert' te bestrijden. ${ }^{233}$ Dit argument verwijst niet zonder meer naar gevaar voor schade (dat wil zeggen fysiek seksueel misbruik). Het vormt vooral een ethisch argument dat is gericht tegen de met een bepaald seksueel doel gevoerde communicatie met zestienminners op internet.

Vóór deze keuze van de wetgever pleit een arrest van de Hoge Raad in een zaak over een man die een tienjarig meisje wilde misbruiken. Voor dat doel had hij voorwerpen (seksuele attributen) en een geldbedrag voorhanden en onder andere via e-mail gecommuniceerd met een derde, die voor de verdachte dat tienjarige meisje zou kunnen regelen. Het meisje bleek niet te bestaan. Het was bedacht door een televisiemaker die de verdachte in de val wilde lokken. De verdachte werd veroordeeld wegens het voorbereiden van onder meer het seksueel binnendringen van een persoon onder de twaalf jaar (art. 46 jo. 244 Sr). De verdediging stelde dat er sprake was van een absoluut ondeugdelijk object en er om die reden nooit sprake

23 I De term lokpuber dekt de lading overigens niet. Allereerst kan de ander zich voordoen als een puber, maar ook als iemand die volgens algemeen spraakgebruik nog geen puber is. Daarnaast wijst de term lokken te veel op uitlokken, terwijl het nu juist niet de bedoeling is dat de groomer wordt uitgelokt.

232 Kamerstukken II 20I5/I6, 34 372, nr. 3, bijlage Advies College van Procureurs-Generaal.

233 Kamerstukken II 20I5/I6, 34 372, nr. 3, p. 7I. Vgl. Smeets 20I3, p. 337 die erop wijst dat bepaald politieonderzoek wel erg gericht was op bepaalde groepen van personen, namelijk homoseksuele mannen. 
kon zijn van strafbare voorbereiding. Dat verweer werd door het hof verworpen en de Hoge Raad liet dat oordeel in stand. Hij overwoog daarbij:

'De middelen stellen daarmee echter aan de strafbaarheid van de voorbereiding van een misdrijf een eis die de wet niet kent en die ook niet bij het karakter van strafbare voorbereiding past. Voldoende is dat uit de bewijsvoering kan worden afgeleid dat de bewezenverklaarde gedragingen strekten ter voorbereiding van feiten als in de bewezenverklaring bedoeld en dat het opzet van de verdachte op het begaan daarvan was gericht. ${ }^{234}$

Met een zekere stelligheid wees de Hoge Raad af dat een absoluut ondeugdelijk object aan de strafbaarheid van voorbereidingshandelingen in de weg staat. Dat is primair voor art. 46 Sr relevant, maar lijkt ook voor voorbereidingsdelicten zoals art. 248 e Sr niet zonder belang. ${ }^{235}$ De Hoge Raad verwijst in zijn overweging naar 'de voorbereiding van een misdrijf', niet naar de voorbereiding als bedoeld in art. $46 \mathrm{Sr}$. Ook 'strafbare voorbereiding' lijkt een breder bereik te suggereren dan alleen art. 46 Sr. Volgens de Hoge Raad kan mede uit het karakter van voorbereidingshandelingen worden afgeleid dat ondeugdelijkheid van het object niet aan strafbaarheid in de weg hoeft te staan. De Hoge Raad geeft geen inzicht in wat dat karakter volgens hem inhoudt. De advocaat-generaal Vegter wees in zijn conclusie vóór het onderhavige arrest erop dat voorbereidingshandelingen (hij doelt wel slechts op art. $46 \mathrm{Sr}$ ) geen actueel of concreet gevaarzettend karakter hebben, maar een abstract gevaarzettend karakter. Het gaat om het doel dat de verdachte beoogde te bereiken en de handelingen die hij heeft verricht om dat doel te bereiken. Dat het doel niet kon worden bereikt, doet niet af aan de omstandigheid dat in de voorstelling van de verdachte het doel wel kon worden bereikt en hij zich moeite had getroost om dat doel te bereiken (communicatie, voorstel doen tot een ontmoeting, handelingen verrichten om de ontmoeting te verwezenlijken). ${ }^{236}$ Wat ontbreekt aan concreet gevaarzettende handelingen kan worden gecompenseerd door de intentie van de verdachte. Handelingen die, gelet op de intentie van de verdachte, in concreto niet, maar wel in abstracto gevaarzettend zijn, zijn met die intentie voldoende om strafbare voorbereidingshandelingen aan te nemen. In de voorgestelde wijziging van art. $248 \mathrm{e}$ Sr wordt het abstract gevaarzettende karakter van de handelingen tot uitdrukking gebracht, hetgeen niet hoeft te betekenen dat grooming met alleen een in werkelijkheid bestaande persoon strafbaar moet zijn gesteld.

Naast art. 248e Sr wordt ook art. 248a Sr herzien. Het komt als volgt te luiden:

'Hij die door giften of beloften van geld of goed, misbruik van uit feitelijke verhoudingen voortvloeiend overwicht of misleiding een persoon die de leeftijd van achttien jaren nog niet heeft bereikt of iemand die zich voordoet als een persoon die de leeftijd van achttien jaren nog niet heeft bereikt, opzettelijk beweegt ontuchtige handelingen

234 HR 27 mei 20I4, NJ 20I4/338, m.nt. Rozemond.

235 Vgl. G.P.M.F. Mols in zijn annotatie onder HR 27 mei 20I4, Nieuwsbrief Strafrecht 2014/156.

236 A-G Vegter vóór HR 27 mei 20I4, NJ 20I4/338, punt II. 
te plegen of zodanige handelingen van hem te dulden, wordt gestraft met gevangenisstraf van ten hoogste vier jaren of geldboete van de vierde categorie.'

De redenen voor wijziging van art. 248e Sr liggen ook aan de wijziging van art. 248a Sr ten grondslag. Wijziging van art. 248a Sr is door het College van procureurs-generaal bepleit om de lokpuber ook te kunnen (blijven) gebruiken in het kader van de loverboy-problematiek. Loverboys misleiden veelal minderjarige meisjes met giften en beloften waardoor zij uiteindelijk in een situatie terechtkomen dat zij zich moeten prostitueren. ${ }^{237}$ Doordat verder geen verschil wordt gemaakt met art. 248e Sr, lijkt het erop dat de wijziging van art. 248a Sr met het oog op voorkoming van daadwerkelijke ontuchtige handelingen is voorgesteld. Dat wekt de indruk dat art. 248a Sr ook een voorbereidingsdelict is, hetgeen evenwel onjuist is. De nieuwe strafbaarstelling stelt strafbaar het verleiden van iedereen tot ontuchtige handelingen met zichzelf of door een ander. Die ontuchtige handelingen moeten zijn gepleegd wil er sprake zijn van een voltooid delict. Het ligt niet voor de hand dat de verleiding van een meerderjarige die zich als minderjarige voordoet snel een voltooid delict kan opleveren. Wanneer de dader ontuchtige handelingen met zichzelf pleegt ten overstaan van een persoon van wie de dader denkt dat deze minderjarig is, is hij op grond van de nieuwe redactie van art. $248 \mathrm{a} \mathrm{Sr}$ strafbaar. Het sexchatten waarin het 'slachtoffer' aangeeft ontuchtige handelingen met zichzelf te plegen, terwijl het dat in werkelijkheid niet doet, levert echter geen overtreding van art. 248a Sr op, omdat de ontuchtige handelingen naar we mogen aannemen niet hebben plaatsgevonden (iets anders zou tamelijk vreemd zijn). Nauwelijks denkbaar is dat iemand die niet minderjarig is, maar wel voor een minderjarige kan doorgaan, zich in het kader van de opsporing zogenaamd laat verleiden ontuchtige handelingen met een ander te plegen..$^{23^{8}} \mathrm{Al}$ met al lijkt deze wijziging van art. 248 a Sr vooral bedoeld om het bereik van de poging tot verleiding te verruimen. ${ }^{239}$ In de wetsgeschiedenis wordt dat echter niet tot uitdrukking gebracht. Dat wekt ten minste verbazing op, net als het wegvallen van het bewustzijnsvereiste ten aanzien van de leeftijd van het slachtoffer. De herziening van art. 248a Sr vraagt om een duidelijke, eigenstandige rechtvaardiging, waarbij de wetgever zich goed moet afvragen of volstrekt ondenkbare handelingen onder de letter van de wettekst moeten worden gebracht.

\subsection{Poging tot grooming strafbaar?}

Lindenberg en Van Dijk besteden enige aandacht aan de vraag of poging tot grooming strafbaar is. ${ }^{24}$ Een argument daartegen is de algemene opvatting dat poging tot voorbereiding niet strafbaar is. Indien grooming een voorbereidingsdelict is, zou de poging daartoe niet strafbaar kunnen zijn. Ook zou uit de parlementaire geschiedenis van art. 248e Sr kunnen worden afgeleid dat de wetgever niet beoogde poging tot grooming strafbaar te achten: dat zou te ver gaan en niet goed te

237 V. Zanetti, 'De digitale loverboy', Proces 2009, p. 280-292.

238 Zie ook J.S.N. Nan, 'Kroniek van het straf(proces)recht', NJB 20I6, p. 995.

239 In feitenrechtspraak heeft poging tot verleiding van een ander dan een minderjarige wel tot een veroordeling geleid (Rb. Noord-Nederland Io juli 20I4, ECLI:NL:RBNNE:20I4:336I), maar dat lijkt strijdig met de huidige wettekst.

240 Lindenberg en Van Dijk 20I6, p. I83-I86. Zie ook Lindenberg 20I6, par. 3·3. 
handhaven zijn. Argumenten ervoor zijn het Verdrag van Lanzarote en de memorie van toelichting bij het voorstel tot implementatie van dat verdrag. Art. 24 lid 2 van het Verdrag bepaalt dat elke partij 'wetgevende of andere maatregelen neemt die nodig zijn om een poging tot het plegen van een van de overeenkomstig dit Verdrag strafbaar gestelde feiten, indien zulks opzettelijk geschiedt, strafbaar te stellen'. Daarop kunnen lidstaten een uitzondering maken (art. 24 lid 3). Nederland heeft dat niet gedaan en zelfs aangegeven dat poging tot grooming strafbaar is. Het is volgens Lindenberg en Van Dijk echter niet goed hard te maken dat Nederland niet aan zijn verdragsverplichtingen voldoet wanneer het poging tot grooming niet strafbaar acht. Art. 248e Sr wordt door de wetgever en de rechter vrij ruim uitgelegd, wat het veel minder problematisch maakt om poging tot grooming niet strafbaar te achten.

De minister van Veiligheid en Justitie merkte echter met betrekking tot poging tot grooming onlangs het volgende op:

'Artikel 24 van het eerdergenoemde Verdrag van Lanzarote verplicht tot het strafbaar stellen van poging tot (onder andere) grooming, tenzij een partij zich het recht heeft voorbehouden de poging niet toe te passen (artikel 24, derde lid). Nederland heeft zich in het kader van het ratificatietraject van het verdrag (...) op het standpunt gesteld, onder verwijzing naar artikel $45 \mathrm{Sr}$, dat poging tot het plegen van misdrijven in Nederland strafbaar is. Er is geen gebruik gemaakt van de uitzonderingsmogelijkheid die het verdrag biedt. Bij wet is de strafbaarheid van de poging tot grooming derhalve niet uitgesloten. ${ }^{24 \mathrm{I}}$

De strafbaarheid van poging tot grooming moet worden bezien in het licht van de onwenselijkheid van seksuele communicatie op het internet. Hiervoor is opgemerkt dat de minister van Veiligheid en Justitie sexchatting met minderjarigen strafbaar wil stellen. Sexchatting acht hij strafbaar, wanneer dit leidt 'tot het seksueel inkapselen van een kind'. ${ }^{242}$ Kan hiermee poging tot grooming worden bedoeld? Poging tot grooming kan op twee manieren plaatsvinden: de gedraging blijft steken in de fase van communiceren of in de fase van het verwezenlijken van die ontmoeting. In de laatste fase is een deel van de delictsomschrijving vervuld (er is een ontmoeting voorgesteld), terwijl in de eerste fase de communicatie wordt afgebroken voordat een ontmoeting is voorgesteld of er is wel een ontmoeting voorgesteld maar er hebben geen handelingen ter verwezenlijking van die ontmoeting plaatsgevonden. De minister geeft in de memorie van toelichting bij het wetsvoorstel Computercriminaliteit III slechts een voorbeeld van de tweede variant. ${ }^{243}$ In zijn kritische advies wees de Raad van State op de eerste variant en stelde dat wanneer de grooming in deze fase blijft steken, terwijl de communicatie vrij onschuldig was, geen strafbaarheid via de poging zou mogen volgen. ${ }^{244}$

Dat de minister de Raad van State op dit punt niet van repliek heeft gediend, betekent niet dat hij deze variant niet strafbaar acht. Het omgekeerde ligt eerder voor de hand. Uit de gedragingen moet dan het voornemen tot grooming zijn afgeleid,

24I Kamerstukken II 20I5/I6, 34 372, nr. 3, p. 9I.

242 Kamerstukken II 2015/16, 29 279, nr. 300, p. 9.

243 Kamerstukken II 20I5/I6, 34 372, nr. 3, p. 9I.

244 Kamerstukken II 20I5/I6, 34 372, nr. 4. 
terwijl deze 'naar hun uiterlijke verschijningsvorm' een begin van uitvoering van grooming opleveren. Eenvoudig is dat niet, omdat de gedragingen dan neerkomen op het voeren van een gesprek tussen een meerderjarige en een minderjarige via een geautomatiseerd werk. Om daaruit een voornemen tot grooming af te leiden die naar zijn uiterlijke verschijningsvorm kan worden beschouwd als een begin van uitvoering van grooming, lijkt alleen mogelijk wanneer de inhoud van het gesprek seksueel getint is en wordt gehint op een ontmoeting. Zonder dat laatste is niet duidelijk welk delict wordt gepoogd (immers, dergelijke gesprekken kunnen ook een poging tot andere strafbare feiten opleveren), terwijl dat voor poging wel moet worden vastgesteld. ${ }^{245}$ De enkele conversatie op internet tussen een meerderjarige en een minderjarige zonder seksuele connotatie is niet strafbaar. In het andere geval zou iedere leerkracht, sportinstructeur of zomerkampbegeleider niet meer zijn in staat zijn zelf via internet met zijn minderjarige leerlingen of pupillen te communiceren. Ook de minister verlangt voor strafbaarheid dat de communicatie seksueel getint is en met een bepaald doel plaatsvindt. Het lijkt er kortom op dat de eerste variant van poging tot grooming wel strafbaar zou kunnen zijn, zij het slechts in beperkte gevallen. ${ }^{246}$

\subsection{Het bestanddeel 'enige handeling onderneemt gericht op het verwezenlijken van die ontmoeting'}

Het huidige art. 248e Sr bepaalt dat de dader enige handelingen gericht op het verwezenlijken van de ontmoeting moet ondernemen. De ontmoeting moet plaatsvinden met de persoon aan wie hij zich heeft voorgesteld. De Nederlandse wetgever hanteert een ruimere interpretatie van het bestanddeel dan de internationale wetgever. In de rechtspraktijk leidde dat tot de nodige onduidelijkheid. De Hoge Raad heeft in twee arresten (gewezen in 2013 en 20I4) helderheid proberen te scheppen.

In de eerste zaak had de verdachte met het minderjarige slachtoffer (het meisje was ten tijde van de bewezenverklaarde gedragingen twaalf of dertien jaar oud) via Habbo en msn gecommuniceerd en een concrete afspraak gemaakt om elkaar op 9 of Io januari 2010 te ontmoeten en voor het slachtoffer een reisschema opgesteld en het meisje geïnstrueerd op welke wijze ze naar de verdachte moest reizen. Het cassatiemiddel klaagde er onder meer over dat die handelingen niet voldoende zijn om van 'enige handeling gericht op het verwezenlijken van de ontmoeting' te kunnen spreken. De Hoge Raad liet het arrest van het hof in stand. Daarbij aanvaardde hij dat het voorstellen van een ontmoeting en enige handeling gericht op het verwezenlijken daarvan 'één samenhangende handeling' kan betreffen. ${ }^{247}$ Het opstellen van een reisschema met instructie is kennelijk voldoende om te kunnen spreken van 'enige handeling gericht op het verwezenlijken van de ontmoeting'. Dat is op basis van de eerder besproken wetsgeschiedenis te billijken, zij het dat de

245 J. de Hullu, Materieel strafrecht. Over algemene leerstukken van strafrechtelijke aansprakelijkheid naar Nederlands recht, Deventer: Kluwer 20I5, p. 387.

246 Poging tot grooming is niet strafbaar wanneer sprake is van vrijwillige terugtred (art. $46 \mathrm{~b} \mathrm{Sr}$ ). De vraag is of deze rechtsfiguur ook van toepassing is bij een voltooide grooming. Aangenomen wordt dat dit niet het geval is, al zijn er ook argumenten voor het toelaten van vrijwillige terugtred. Zie J.M. ten Voorde, 'Prohibiting Remote Harms: On Endangerment, Citizenship and Control', Utrecht Law Review 20I4, p. I76-I78.

247 HR I4 mei 2013, NJ 2013/296. 
wettekst met het onderdeel 'enige handeling onderneemt' toch lijkt te veronderstellen dat het doen van een voorstel en de handeling gericht op verwezenlijking van die ontmoeting twee te onderscheiden handelingen zijn. De Hoge Raad lijkt dat onderscheid in het onderhavige arrest in stand te houden, maar het betekent niet dat de handelingen niet tijdens hetzelfde gesprek mogen plaatsvinden.

In de tweede zaak had de verdachte herhaaldelijk contact met een elfjarig meisje. Tijdens die gesprekken gaf verdachte onder meer aan te hopen dat ze seks zouden gaan hebben. Bij herhaling drong hij tevergeefs aan op een ontmoeting, in het bos, in een winkelcentrum en zelfs bij haar thuis. Hij noemde tijdens de gesprekken een concrete middag, avond of tijdstip. Hij zette het meisje tijdens hun gesprekken onder druk. Verdachte en het meisje hadden elkaars telefoonnummer. Volgens het hof kon op grond daarvan niet alleen worden gesproken van een voorstel tot een ontmoeting; er was ook sprake van enige handeling gericht op het verwezenlijken van die ontmoeting. Volgens het hof deed verdachte er alles aan een ontmoeting met het meisje te realiseren. Dat de ontmoetingsplaats niet altijd duidelijk was, maakte volgens het hof niet dat er geen sprake is geweest van een handeling gericht op het verwezenlijken van de ontmoeting. Het hebben van elkaars telefoonnummer maakte het volgens het hof namelijk mogelijk 'op elk gewenst moment' een ontmoetingsplaats af te spreken.

De advocaat-generaal, Spronken, concludeerde tot vernietiging van het arrest. Ter onderbouwing daarvan stelde zij dat in ieder geval 'concrete afspraken moeten zijn gemaakt'. Tevens moest volgens haar 'actie worden ondernomen om een ontmoeting daadwerkelijk te laten plaatsvinden'. Het 'onder druk zetten en manipuleren van het slachtoffer gedurende het chatten en sms'en' viel volgens de advocaat-generaal 'niet onder de categorie concrete gedragingen (...) die gericht zijn op het realiseren van een ontmoeting. Daarvan kan mijns inziens pas sprake zijn als er handelingen worden verricht nadat er een concrete ontmoeting is afgesproken. Dat is in onderhavige zaak niet het geval. ${ }^{248}$ Spronken keerde zich (impliciet) tegen het arrest van 2013 en eiste voor het bewijzen van grooming twee goed van elkaar te onderscheiden fasen: een communicatie- en een actiefase.

De Hoge Raad liet het arrest van het hof echter in stand. Dat de verdachte bij herhaling bij het slachtoffer had aangedrongen op een ontmoeting en voorstellen had gedaan elkaar te ontmoeten op concrete plaatsen (bos, winkelcentrum, bij haar thuis) en daarbij een concrete middag, avond, of concreet tijdstip heeft genoemd, was volgens de Hoge Raad voldoende om te kunnen spreken van het 'voorstellen van een ontmoeting'. Ter realisering van die ontmoeting (om vervolgens ontuchtige handelingen te plegen) had het hof vastgesteld dat verdachte 'er bij het slachtoffer herhaaldelijk op [heeft] aangedrongen dat de ontmoetingen snel zouden plaatsvinden en hij (...) haar onder druk [heeft] gezet', alsmede dat de verdachte 'in het kader van het concretiseren van een afspraak zijn telefoonnummer [heeft] gegeven' aan het slachtoffer. Die handelingen waren volgens de Hoge Raad voldoende om te kunnen spreken van 'enige handeling ter verwezenlijking van die ontmoeting'. ${ }^{249}$

248 Conclusie A-G Spronken vóór HR II november 20I4, NJ 20I5/73, m.nt. Keijzer, punt I2, I8. 249 HR II november 20I4, NJ 20I5/73, m.nt. Keijzer. 
De Hoge Raad somde de verschillende vaststellingen van het hof op met behulp van een nummering (i, ii en iii). Onder nummer (i) werd de fase omschreven waarin een ontmoeting werd voorgesteld, terwijl de nummers (ii) en (iii) de handelingen ter verwezenlijking van die ontmoeting beschreven. Dat wekt de indruk van een chronologie en goed te onderscheiden fasen. Wanneer de inhoud van de nummers nader wordt bekeken, valt op die goed te onderscheiden fasen wel wat af te dingen. De handelingen onder ii en iii omschreef de Hoge Raad als volgt: '(ii) de verdachte heeft er bij het slachtoffer herhaaldelijk op aangedrongen dat de ontmoetingen snel zouden plaatsvinden en hij heeft haar onder druk gezet; en (iii) de verdachte heeft het slachtoffer in het kader van het concretiseren van een afspraak zijn telefoonnummer gegeven'. Deze gedragingen kunnen op twee manieren worden gelezen. Spronken (en nadien ook enkele commentatoren op het arrest) ziet ze als onderdeel van de communicatiefase. Een ontmoeting is nog allesbehalve zeker, ook omdat het slachtoffer niet toehapt, en de verdachte is op verschillende manieren bezig een ontmoeting te regelen. Van een vervolgstap of 'nieuw initiatief' kan niet worden gesproken. ${ }^{25}$ Aan de andere kant is bewijs voorhanden dat verdachte diverse concrete ontmoetingen heeft voorgesteld ('in het bos, het winkelcentrum, bij haar thuis, waarbij een concrete middag, avond dan wel tijdstip zijn genoemd', zoals de Hoge Raad het onder (i) stelt). In de omschrijving van de Hoge Raad is het slachtoffer onder druk gezet en werd er bij het meisje op aangedrongen 'dat de ontmoetingen snel zouden plaatsvinden' en heeft hij zijn telefoonnummer gegeven 'in het kader van het concretiseren van een afspraak'. Het eerste citaat wekt de indruk dat de onder (i) genoemde voorstellen tot een ontmoeting gevolgd werden door drang en druk om de ontmoeting te verwezenlijken. Het laatste citaat lijkt veel minder nauw verbonden met de onder (i) genoemde voorstellen, omdat wordt gesproken van het concretiseren van 'een' afspraak. De Hoge Raad leidde hier echter uit af dat ook die handelingen waren gericht op het verwezenlijken van 'de voorgestelde ontmoeting zoals bedoeld onder (i)'. Daarmee lijkt de Hoge Raad de indruk te wekken 'nieuw initiatief' van de verdachte te verlangen. De vraag is dan welk initiatief kan worden beschouwd als een handeling van de verdachte ter verwezenlijking van de voorgestelde ontmoeting.

Betwijfeld kan worden of de omstandigheden die de Hoge Raad onder (iii) noemt wel voldoende 'nieuw initiatief' opleveren om van een handeling ter verwezenlijking van de ontmoeting te spreken. Immers, er wordt niet gesproken van 'de' ontmoeting maar van 'een afspraak', terwijl de term concretiseren in dit verband kan slaan op het verwezenlijken van een ontmoeting en niet zonder meer uitsluit dat zij enkel slaat op het voorstellen van een ontmoeting. De combinatie met 'een afspraak' wekt niet de indruk dat die ontmoeting al is voorgesteld. De omstandigheden, genoemd onder (ii), zijn wel concreter (er wordt gesproken van 'de ontmoetingen'), al wordt het verband met de onder (i) genoemde voorstellen tot een ontmoeting pas aan het slot van de overweging van de Hoge Raad gelegd. In ieder geval zou het herhaaldelijk aandringen op het snel plaatsvinden van de ontmoetingen en het onder druk zetten van het slachtoffer kunnen worden beschouwd als het 'onderstrepen [van] de vastheid van het voornemen van de dader om zijn

250 Conclusie A-G Spronken vóór HR II november 20I4, NJ 20I5/73, m.nt. Keijzer, punt I8; Keijzer onder HR II november 20I4, NJ 20I5/73, punt 5; Vermeij onder HR II november 20I4, Nieuwsbrief Strafrecht 20I5/2I. 
digitaal misbruik daadwerkelijk om te zetten in het plegen van fysiek misbruik. Vanuit het oogpunt van een effectieve bescherming van kinderen is het zaak dat tegen deze gedragingen strafrechtelijk kan worden opgetreden. ${ }^{251}$ Deze passage uit de memorie van toelichting werd door de Hoge Raad aangehaald. De daarin genoemde gedragingen vormen kennelijk 'concrete voorbereidingen' die worden getroffen om de ontmoeting te verwezenlijken. De vraag is of dit het treffen van concrete voorbereidingen zijn. De wetgever spreekt bij wijze van voorbeeld over het zich begeven naar de voor de ontmoeting afgesproken plek en het voorzien van een routebeschrijving aan het slachtoffer naar die plek. Dat zijn slechts voorbeelden, al zijn ze van een andere orde dan het onder druk zetten of herhaaldelijk aandringen op het snel plaatsvinden van ontmoetingen. Tegelijkertijd wil de wetgever met de strafbaarstelling van grooming het 'benaderen en verleiden van een kind' effectiever kunnen bestrijden. Vanuit dat perspectief valt het te begrijpen dat de Hoge Raad voor een ruime omschrijving heeft gekozen. ${ }^{252}$ Een en ander heeft wel tot gevolg dat de relatie tussen het voorstellen van een ontmoeting en enige handeling gericht op het verwezenlijken van die ontmoeting is verwaterd. Weliswaar legde de Hoge Raad in zijn arrest nog steeds die verbinding, maar de onder (ii) en (iii) genoemde omstandigheden zijn niet direct gekoppeld aan de verschillende onder (i) genoemde voorstellen tot ontmoeting. Ook het hof legde die verbinding niet zonder meer duidelijk.

Het arrest van 2014 laat kortom zien dat de feitenrechter niet hoeft vast te stellen dat het voorstellen van een ontmoeting en de gedragingen ter verwezenlijking daarvan dezelfde ontmoeting moeten betreffen. De Hoge Raad verlangt enigszins concrete handelingen die op een ontmoeting zijn gericht. Zij hoeven echter geen activiteiten buiten de online wereld te betreffen. Gedragingen op het internet kunnen volstaan. De verdachte hoeft zijn huis nog niet te hebben verlaten, hij hoeft zelfs niet uit zijn luie stoel te zijn opgestaan, om toch handelingen te verrichten die zijn gericht op de verwezenlijking van een ontmoeting. Daardoor kunnen de communicatie- en actiefase in elkaar overlopen. Dat contrasteert met de oorspronkelijke bedoeling van de wetgever die de enkele communicatie met een kind niet strafbaar achtte. Een 'zodanige verschuiving van de strafbaarheid naar de voorfase zou te ver voeren', aldus de minister van Justitie. ${ }^{253}$ Inmiddels liggen de kaarten kennelijk anders, of anders gezegd: is het beeld genuanceerder. De minister van Veiligheid en Justitie heeft immers aangegeven dat sexchatting strafbaar is, mits dit leidt 'tot het seksueel inkapselen van een kind'. Daarvoor zijn activiteiten in de offline wereld niet nodig. De actiefase wordt in deze omschrijving gereduceerd tot gedragingen die heel goed enkel op internet plaatsvinden. De gedragingen die volgens de Hoge Raad in het zojuist besproken arrest grooming opleverden, kunnen als voorbeeld van het seksueel inkapselen van het kind worden beschouwd. Zo bezien lijkt het erop dat de Hoge Raad de tijdgeest goed heeft aangevoeld.

25I Kamerstukken II 2008/o9, 3I 8Io, nr. 3, p. 7.

252 De Bruijn-Lückers onder HR II november 20I4, Jurisprudentie in Nederland 20I4/227.

253 Kamerstukken II 2008/o9, 3I 8Io, nr. 3, p. 6-7. 


\subsection{Relatie tussen grooming en poging tot verleiding}

De zojuist besproken uitspraken van de Hoge Raad zijn in een wat breder perspectief bezien minder bijzonder. Tijdens de totstandkoming van art. 248e Sr werd deze bepaling afgezet tegen art. 248 a Sr. Uit de memorie van toelichting blijkt dat vormen van grooming weliswaar onder art. 248a Sr kunnen vallen, tegelijkertijd zou art. 248e Sr een leemte vullen in de gevallen waarin van 'het plegen van een feitelijke seksuele handeling of een begin van uitvoering daartoe' geen sprake is. ${ }^{254}$ Op het eerste gezicht is dit juist. Voor grooming is niet nodig dat ontuchtige handelingen met een zestienminner worden gepleegd. Evenmin hoeft er sprake te zijn van een begin van uitvoering daarvan.

Wanneer we de rechtspraak van poging tot verleiding in herinnering roepen, dan blijkt daarvoor voldoende het doen van beloften (bijvoorbeeld de belofte van geld of drugs). Die beloften kunnen ook langs digitale weg worden gedaan. Tevens moet het voor het slachtoffer duidelijk zijn dat een tegenprestatie in de vorm van het plegen of dulden van ontuchtige handelingen van hem wordt verlangd. Een concrete afspraak voor die tegenprestatie hoeft niet te zijn gemaakt. De tegenprestatie kan ook online worden geleverd. Art. 248a Sr stelt strafbaar het plegen van ontuchtige handelingen, wat betekent dat die handelingen ook door het slachtoffer (jonger dan achttien jaar) kunnen worden gepleegd die voor de ander via een webcam zichtbaar worden. ${ }^{255}$ Een begin van uitvoering van ontuchtige handelingen is niet nodig om van poging tot verleiding te spreken. Vergelijken we dit met grooming, dan zijn verleidingshandelingen volgens de wet niet nodig en hoeft het voor het slachtoffer tijdens de communicatie met de ander niet duidelijk te zijn met welk doel die ander een ontmoeting voorstelt. Wel moet er sprake zijn van een voorstel tot een ontmoeting, dat ook gelet op rechtspraak van de Hoge Raad een vrij concreet voorstel moet behelzen. De ontmoeting moet door de verdachte met het in art. $248 \mathrm{e} \mathrm{Sr}$ omschreven oogmerk zijn voorgesteld. Dat oogmerk is tweeledig: het plegen van ontuchtige handelingen met een zestienminner of het vervaardigen van een afbeelding van een seksuele gedraging waarbij die persoon is betrokken. Het tweede deel van het oogmerk maakt het mogelijk de gedraging online te laten plaatsvinden, ook wanneer wordt geëist dat de dader de afbeeldingen vervaardigt. Het voorstel tot een ontmoeting kan, voor zover het doel is ontuchtige handelingen te plegen, slechts betrekking hebben op een plaats in de offline wereld. Daaruit volgt niet, zoals uit rechtspraak van de Hoge Raad blijkt, dat de handelingen ondernomen ter verwezenlijking van die ontmoeting uitsluitend in de offline wereld moeten plaatsvinden; wel moeten de verwezenlijkingshandelingen betrekking hebben op datgene wat in de offline wereld moet gaan plaatsvinden, namelijk ontuchtige handelingen. Die eis wordt in de ten behoeve van dit preadvies bestudeerde feitenrechtspraak over poging tot verleiding niet gesteld.

Een en ander zou erop kunnen duiden dat poging tot verleiding in chronologie niet zozeer na grooming komt, maar eerder naast grooming staat. Sommige handelingen kunnen geen poging tot verleiding opleveren, bijvoorbeeld bij gebrek aan verleidingshandelingen, zij kunnen onder omstandigheden wel grooming

254 Kamerstukken II 2008/o9, 3I 8Io, nr. 3, p. 6.

255 Lindenberg en Van Dijk 20I6, p. 62-8I. 
opleveren. Sommige handelingen kunnen geen grooming opleveren, maar zijn wel voldoende voor poging tot verleiding. Dat leidt tot de conclusie, anders dan de wetgever kennelijk voor ogen had, dat grooming geen strafbaarstelling is die vóór poging tot verleiding moet worden gepositioneerd, maar soms met poging tot verleiding overlapt en soms daaraan complementair is. Dit lijkt bijzonder; in het ene geval leveren de handelingen een poging tot misdrijf op, in het andere geval een voltooid delict dat een voorbereidingsdelict is. Op het niveau van de delictsomschrijvingen kan worden opgemerkt dat de verschillen tussen beide bepalingen, in de leeftijd van het slachtoffer en in de aard van de ontuchtige handelingen (wel of niet online), vragen oproepen, zeker wanneer beide bepalingen kennelijk zo aan elkaar verwant zijn. De verschillen worden bij de eerder besproken voorgestelde wijziging van art. 248 a en 248 e Sr niet weggenomen. De wetgever is hier aan zet.

\section{$7 \quad$ Slotbeschouwing}

Seksuele delicten manifesteren zich allang niet meer alleen in de offline wereld. Het internet wordt veelvuldig gebruikt om seksuele delicten te kunnen begaan. De gedragingen die op of met behulp van het internet worden begaan, zijn ten dele een digitale voortzetting van gedragingen die daarvoor al in de offline wereld plaatsvonden. Met behulp van de strafwet probeert de overheid het seksuele leven tot op zekere hoogte te reguleren. Daarbij beweegt de overheid zich telkens tussen Scylla (zedenmeester) en Charybdis ('laissez-faire'). Dan weer meent de overheid zich in het seksuele leven van haar burgers te mogen begeven, om vervolgens beleid te ontwikkelen dat uitgaat van seksuele vrijheid, de ontdekking van seksualiteit door minderjarigen daaronder begrepen. De spanning die door een democratisch gekozen wetgever die zich aan de regels van de rechtsstaat dient te houden telkens gevoeld wordt wanneer de vraag is of bepaalde gedragingen onder het bereik van de strafwet moeten worden gebracht, manifesteert zich bij uitstek op het terrein van de seksualiteit. Weinig onderwerpen in het strafrecht zijn zo beladen als de seksuele delicten. Die spanning wordt op internet wellicht nog sterker gevoeld; het internet is immers het medium waar vrijheid vooropstaat en ervan uit wordt gegaan dat burgers zichzelf weten te beheersen. Dat burgers zich op internet niet altijd weten te beheersen, moge reeds blijken uit de rechtspraak die in dit preadvies de revue is gepasseerd. De Nederlandse overheid zoekt naar mogelijkheden het internetverkeer dat betrekking heeft op seks te reguleren en tot op zekere hoogte, al dan niet met behulp van het strafrecht, aan banden te leggen.

De laatste jaren heeft de Nederlandse overheid, voor zover het gaat om op of met behulp van internet gepleegde seksuele delicten en geïnspireerd door internationale afspraken, vooral nadruk gelegd op de bestrijding van kinderporno en grooming. Beide onderwerpen zijn aan elkaar verwant. Allereerst hebben zij betrekking op een specifieke categorie seksuele delicten, namelijk die waarbij minderjarigen slachtoffer zijn. Zowel kinderporno (art. 24ob Sr) als grooming (art. $248 \mathrm{e} \mathrm{Sr}$ ) werd strafbaar gesteld om minderjarigen te beschermen tegen gedragingen die deze minderjarigen mogelijk schade zouden kunnen berokkenen. Het gevaar voor schade is weliswaar nog steeds een belangrijk argument voor strafbaarstelling, de bescherming van minderjarigen als belangrijkste te beschermen rechtsgoed biedt ruimte voor andere argumenten dan alleen (gevaar voor) 
schade. Zo zagen we dat het tegengaan van een subversieve pedofiele subcultuur een steeds belangrijker argument is geworden voor de strafbaarstelling van zowel kinderporno als grooming. Bij het ontbreken van (gevaar voor) schade, door virtuele kinderporno en virtuele grooming, zocht de wetgever naar andere argumenten voor strafbaarstelling. Hoewel het tegengaan van een subversieve pedofiele subcultuur vooral van belang is als rechtvaardiging van strafbaarstellingen van virtuele gedragingen, is niet ondenkbaar dat het belang van dit argument de komende jaren zal groeien. De verwantschap tussen kinderporno en grooming met andere strafbaarstellingen in Titel XIV (zoals art. 240, 240a en art. 248a Sr) maakt het mogelijk dat dit argument ook bij die strafbaarstellingen wordt gebruikt ter rechtvaardiging van een verruiming van die strafbaarstellingen voor zover zij de virtuele wereld betreffen. De wijziging van de delictsomschrijving van art. 248a Sr, zoals besproken in par. 6.4, is hiervan een voorbeeld.

Hier wordt niet de suggestie gewekt dat anders over een pedofiele subcultuur moet worden gedacht, wel lijkt het mij de vraag of een bepaalde geaardheid het voornaamste argument voor strafbaarstelling mag zijn. Inzet van het strafrecht is gerechtvaardigd daar waar het gaat om het bestraffen en op die manier voorkomen van nieuw onrechtmatig handelen. Niet de geaardheid van een persoon, maar zijn handelen (als gevolg van die geaardheid) wordt beoordeeld en afgestraft. De geaardheid heeft in het Nederlandse strafrecht geen betekenis bij de beoordeling van de feiten en de juridische kwalificatie van het gedrag. Evenmin speelt de geaardheid van de dader een rol bij het bepalen van diens schuld. Zij kan slechts een rol spelen bij het bepalen van de (door de rechter) op te leggen straf of maatregel.

Dat niet het zijn, maar het doen wordt bestraft, is onvolledig nu de vraag welk doen precies strafbaar is, onbeantwoord blijft. Die vraag is bij seksuele delicten die op of met behulp van internet worden begaan, actueel. De minister van Veiligheid en Justitie heeft diverse onderwerpen genoemd die zijn aandacht hebben en in een aantal gevallen tot nieuwe wetgeving moeten leiden. Genoemd werden onder andere sexting en sexchatting. Bestaande strafwetgeving biedt nu al mogelijkheden tegen deze fenomenen op te treden. Met betrekking tot sexting en sexchatting geldt daarbij wel dat de enkele communicatie over seks tussen minderjarigen, tussen meerderjarigen of tussen minderjarigen en meerderjarigen niet zonder meer strafbaar is. Het strafrecht komt bij deze gedragingen veelal pas in beeld wanneer zij op een bepaald in de wet omschreven doel zijn gericht. Dat doel, of beter die doelen, want uit het voorgaande blijkt dat aan verschillende strafbaarstellingen verschillende doelen ten grondslag liggen, zijn direct tot de seksuele delicten te herleiden of houden daarmee indirect verband. Verschillende vormen van seksuele communicatie zijn strafbaar als voorbereiding van een seksueel delict of als een op zichzelf staand voltooid delict, die tot doel hebben de persoonlijke vrijheid of de eer of goede naam van het slachtoffer te beschermen. Daarbij maakt het niet altijd uit of de seksuele communicatie met minderjarigen plaatsvindt. Bepaalde vormen van seksuele communicatie met meerderjarigen zijn strafbaar op grond van bestaande strafbaarstellingen. Hoewel in de delictsomschrijving van deze strafbaarstellingen veelal een te bereiken doel is vermeld, zagen we dat daaraan niet heel hoge eisen worden gesteld. Bij belaging en poging tot verleiding is in de rechtspraak het te bereiken doel bijvoorbeeld op afstand gezet. Daarmee is de enkele seksuele communicatie weliswaar niet strafbaar, heel veel meer dan communicatie is op dit moment niet nodig om van belaging of poging tot verleiding te spreken. Het is dus nu al mogelijk vormen van sexchatting te bestraffen. De beledigingsartikelen 
maken het mogelijk vormen van sexting te bestraffen. De strafbaarstelling van grooming lijkt steeds meer op te schuiven naar een strafbaarstelling van sexchatting, ook al biedt de internationale regelgeving waarop grooming is gebaseerd hiervoor niet zonder meer steun. Tegelijkertijd is er op basis van die regelgeving (en met name de preambule van de Richtlijn 20II/93/EU) aanleiding te veronderstellen dat het een kwestie van tijd is eer wordt aangedrongen op de aanpak van sexting en sexchatting, al dan niet met behulp van het strafrecht.

De minister lijkt met zijn voorstel die kant op te willen gaan. Sexting en sexchatting zouden strafbaar moeten zijn, ook zonder dat daarmee een bepaald (al dan niet verder gelegen) doel wordt beoogd te bereiken, terwijl de te bestraffen gedraging de enkele communicatie met een minderjarige betreft. De vraag is waarom de enkele communicatie over seks zo ernstig is dat zij onder het bereik van de strafwet moet vallen. Twee opmerkingen zijn hier op zijn plaats. In de eerste plaats lijken de opmerkingen van de minister zich niet uit te strekken tot adolescenten, nu de minister heeft aangegeven dat seksuele communicatie tussen adolescenten behoort tot de seksuele ontplooiing van deze jongeren. De opmerkingen beperken zich tot minderjarigen die nog geen adolescent zijn. Kennelijk voldoet het bestaande strafrechtelijk kader om sexchatting met (en tussen) adolescenten met behulp van het strafrecht aan te pakken. Daaruit volgt, zo kan in de tweede plaats worden opgemerkt, dat het bestaande strafrechtelijk kader alleen tekortschiet bij minderjarigen die niet tot de groep adolescenten behoren. Dat is ten dele juist. Wanneer we aannemen dat sexting en sexchatting ook kan plaatsvinden door het tonen van afbeeldingen of door confrontatie met voor de eerbaarheid aanstotelijke of schennende handelingen met behulp van een webcam, biedt de strafwet diverse mogelijkheden tegen deze vormen van sexting en sexchatting op te treden. Sexchatting bestaande uit het enkel voeren van gesprekken, zonder duidelijk doel en zonder dat deze gesprekken stelselmatig plaatsvinden of gepaard gaan met het doen van zekere beloften of door middel van bedreiging met geweld of een andere feitelijkheid, lijkt op dit moment inderdaad niet strafbaar te zijn. Wanneer het gaat om jonge kinderen wekt dat bevreemding. Dat de minister deze omissie wil herstellen, is dus verklaarbaar. Dat neemt niet weg dat er de nodige afbakeningsvragen kunnen worden gesteld. Moet sexting of sexchatting door twee minderjarigen strafbaar worden gesteld? Moeten eisen worden gesteld aan de inhoud van een gesprek, of zou elke woordenwisseling over seks strafbaar moeten zijn? Moet ook offline sexting of sexchatting strafbaar worden gesteld en (in dat geval) hoe wordt voorkomen dat bijvoorbeeld seksuele voorlichting (door ouders, opvoeders of leerkrachten) ook strafbaar wordt? Is het altijd nodig jongeren te beschermen tegen hun, voor volwassenen soms onbegrijpelijke, experimenteergedrag? Dergelijke vraagstukken brengen ons terug bij een eerdere vraag: dient de enkele seksuele communicatie zonder dat daarmee een illegitiem doel wordt beoogd strafbaar te zijn? Het lijkt niet vanzelfsprekend zover te moeten gaan, terwijl de rechtspraak over art. $248 \mathrm{a}$ en $248 \mathrm{e}$ Sr tot de conclusie zou kunnen leiden dat zover ook niet hoeft te worden gegaan. Daarnaast kan de wetgever zich afvragen in hoeverre hij de beperkte uitleg van art. 239 en $240 \mathrm{Sr}$, voor zover het gaat om straffeloosheid van schennis van de eerbaarheid in woord (of geschrift), wil blijven omarmen. Hoe het ook zij, de wetgever zal er een flinke kluif aan hebben een aparte strafbaarstelling te ontwikkelen waarin communicatie over seks niet helemaal wordt verboden. Hij heeft het zich daarbij niet eenvoudig gemaakt. Door de nadruk te leggen op de bescherming van minderjarigen, is een beperking niet eenvoudig aan te 
brengen. Het risico bestaat dat elke vorm van sexting of sexchatting als een uiting van pedofilie wordt beschouwd. Het komt mij daarom voor dat aan de eventuele strafbaarstelling van sexting of sexchatting een grondige analyse van de inhoud en reikwijdte van het rechtsbelang 'de bescherming van minderjarigen' vooraf zal moeten gaan, waarbij ook duidelijk wordt welke vrijheid volwassenen aan minderjarigen willen geven hun eigen seksualiteit te ontwikkelen, ${ }^{256}$ daarbij kennisnemend van wat jongeren daadwerkelijk op internet uitspoken met hun lichaam en aan welke seksuele verleidingen zij worden blootgesteld en zich willen blootstellen. Met een heldere omschrijving van het rechtsbelang kan worden bepaald of sexting en sexchatting met minderjarigen strafbaar moeten worden gesteld en in hoeverre de bestaande strafbaarstellingen afdoende soelaas bieden. Eenvoudige oplossingen, die op grond van bestaande wetgeving wel denkbaar zijn (zoals een ruimere interpretatie van art. $239 \mathrm{Sr}$ door ook het gesproken woord onder het bereik van die strafbepaling te laten vallen), leggen het probleem op het bord van de rechter. Dat lijkt, ook al is dit een typisch Nederlandse oplossing, gelet op de complexiteit van de materie niet wenselijk. De aanduiding en invulling van rechtsbelangen zijn nog steeds primair een zaak voor de wetgever.

De minister onderzoekt of sextortion strafbaar moet worden gesteld. Op die manier zou de bestaande versnippering van wetgeving worden tegengegaan. Verschillende varianten van dit fenomeen zijn op grond van het geldend recht reeds strafbaar, als vorm van afpersing en afdreiging. Ook andere strafbare feiten, inclusief seksuele delicten, komen in beeld. Op basis daarvan werd de vraag geformuleerd of een aparte strafbaarstelling een meerwaarde heeft. Die meerwaarde lijkt een aparte strafbaarstelling slechts te hebben wanneer het vanuit het oogpunt van overzichtelijkheid aan te bevelen zou zijn om delicten die hetzelfde rechtsbelang beogen te beschermen zo veel mogelijk onder te brengen in dezelfde titel van het Wetboek. Daar wringt bij seksuele afpersing echter de schoen. De diversiteit van gedragingen die onder de noemer van seksuele afpersing kunnen worden gebracht, betreffen niet alleen de seksuele vrijheid (of de bescherming van minderjarigen). De seksuele vrijheid lijkt slechts een deelbelang dat met seksuele afpersing in het geding kan komen. De gedragingen wijzen erop dat naast de seksuele vrijheid ook de persoonlijke vrijheid, in het bijzonder de persoonlijke levenssfeer, in het gedrang komt. Door seksuele afpersing als apart zedendelict in Titel XIV op te nemen bestaat het risico seksuele afpersing tot een bepaald aspect te verengen, terwijl er ook wat voor te zeggen valt om het fenomeen te bezien in het licht van alle belangen die door seksuele afpersing kunnen worden geschonden. Juist wanneer wordt aangenomen dat met seksuele afpersing de persoonlijke vrijheid in het gedrang komt, kunnen de verschillende varianten ervan afzonderlijk worden beschermd, terwijl de deelbelangen voldoende door het rechtsbelang van de persoonlijke vrijheid worden afgedekt. Op die manier wordt voorkomen dat al te creatieve vormen van seksuele afpersing, die volstrekt niet door de beugel kunnen, buiten het bereik van de strafwet zullen vallen.

De strafbaarheid van wraakporno lijkt onder andere te kunnen worden gerechtvaardigd doordat de eer of goede naam en een specifiek deel van de persoonlijke vrijheid, namelijk de privacy, in het geding is. De effecten van dit fenomeen op

256 Vgl. A.A. Hasinoff, Sexting Panic. Rethinking Criminalization, Privacy, and Consent, Urbana/Chicago/ Springfield: University of Illinois Press 2015. 
personen blijken indringend, wellicht omdat wraakporno niet alleen op seksualiteit betrekking heeft. In het geding is de persoon in de verschillende hoedanigheden waarin hij aan het maatschappelijk verkeer deelneemt. Strafrechtelijk wordt op verschillende manieren tegen wraakporno opgetreden. Deze adresseren niet het motief waarmee pornografisch materiaal op internet wordt geplaatst en verspreid. Het ontbreken van een verwijzing naar een motief in de relevante strafbaarstellingen kan de indruk wekken dat aan het motief voor de strafbaarheid weinig betekenis toekomt. Wanneer juist het motief, het nemen van wraak, zo'n wezenlijk element van de gedraging is, roept dat de vraag op of een aparte strafbaarstelling, waarbij dat motief een plaats wordt gegeven, gewenst is. Dat is niet zonder meer vanzelfsprekend. Niet alleen is het opnemen van een motief in een delictsomschrijving in het Nederlandse strafrecht niet erg gebruikelijk, net als bij seksuele afpersing is de vraag of daardoor het bereik van de strafbepaling niet te veel wordt beperkt. De ene wraak is de andere niet, terwijl ook de consequenties van de genomen wraak blijken te verschillen. Relevanter lijkt het te bezien of het tegen de wil van de ander openbaren van niet-openbare gegevens, zoals naaktfoto's, terwijl die gegevens met al dan niet uitdrukkelijke toestemming zijn verkregen, strafbaar zou moeten worden gesteld. Het voorgestelde art. I38c Sr sluit in de huidige omschrijving uit dat het op een later moment intrekken van toestemming tot strafbaarheid leidt.

Strafbaarstelling van wraakporno lijkt niet zozeer gewenst vanwege het openbaar maken van gegevens maar vanwege de inhoud van die gegevens. Die inhoud is privé, openbaring ervan tast de reputatie van het slachtoffer aan met alle nadelige gevolgen van dien. Ligt het dan niet meer voor de hand aansluiting te zoeken bij de strafbaarstellingen in Titel XVII van het Tweede Boek (Schending van geheimen)? Strafbaar zou kunnen worden gesteld het openbaar maken van gegevens waarvan men weet of redelijkerwijs moet vermoeden dat die ook ten tijde van het verkrijgen ervan niet openbaar mochten worden gemaakt. Ook in een op deze wijze vormgegeven strafbaarstelling staat het motief niet centraal. Wel ligt aan bestraffing ten grondslag het schenden van het vertrouwen dat de ene persoon in de andere persoon stelde ten tijde van het maken of verkrijgen van materiaal dat nooit voor derden was bestemd. Door aan de strafbaarstelling het vertrouwen ten grondslag te leggen wordt met het bestraffen van het schenden daarvan impliciet de boodschap afgegeven dat het nemen van wraak door middel van het openbaren van porno niet onbestraft mag blijven. Dit idee maakt evenwel opnieuw zichtbaar dat de rechtsbelangen die in het geding zijn bij de in dit preadvies besproken seksuele delicten zeer veelzijdig zijn. Er is sprake van een fragmentatie van rechtsbelangen. Dat maakt duidelijk dat het voor de wetgever bijzonder lastig wordt om alle seksuele delicten in één samenhangende titel in het Wetboek onder te brengen op een wijze die de handhaving bevordert en de norminprenting vergroot en de versnippering van de huidige wettelijke regeling daadwerkelijk bestrijdt. Ten aanzien van dat laatste ligt het evenwel niet in de rede dat versnippering volledig kan worden tegengegaan. Gelet op de diversiteit van rechtsbelangen is het samenstellen van één strafbaarstelling misschien wel mogelijk, maar niet zonder meer wenselijk. Bij de voorgenomen herziening van Titel XIV lijkt het daarom gewenst allereerst de in het geding zijnde rechtsbelangen aan een grondige studie te onderwerpen alvorens tot een daadwerkelijke wijziging en aanvulling van deze titel over te gaan. 